
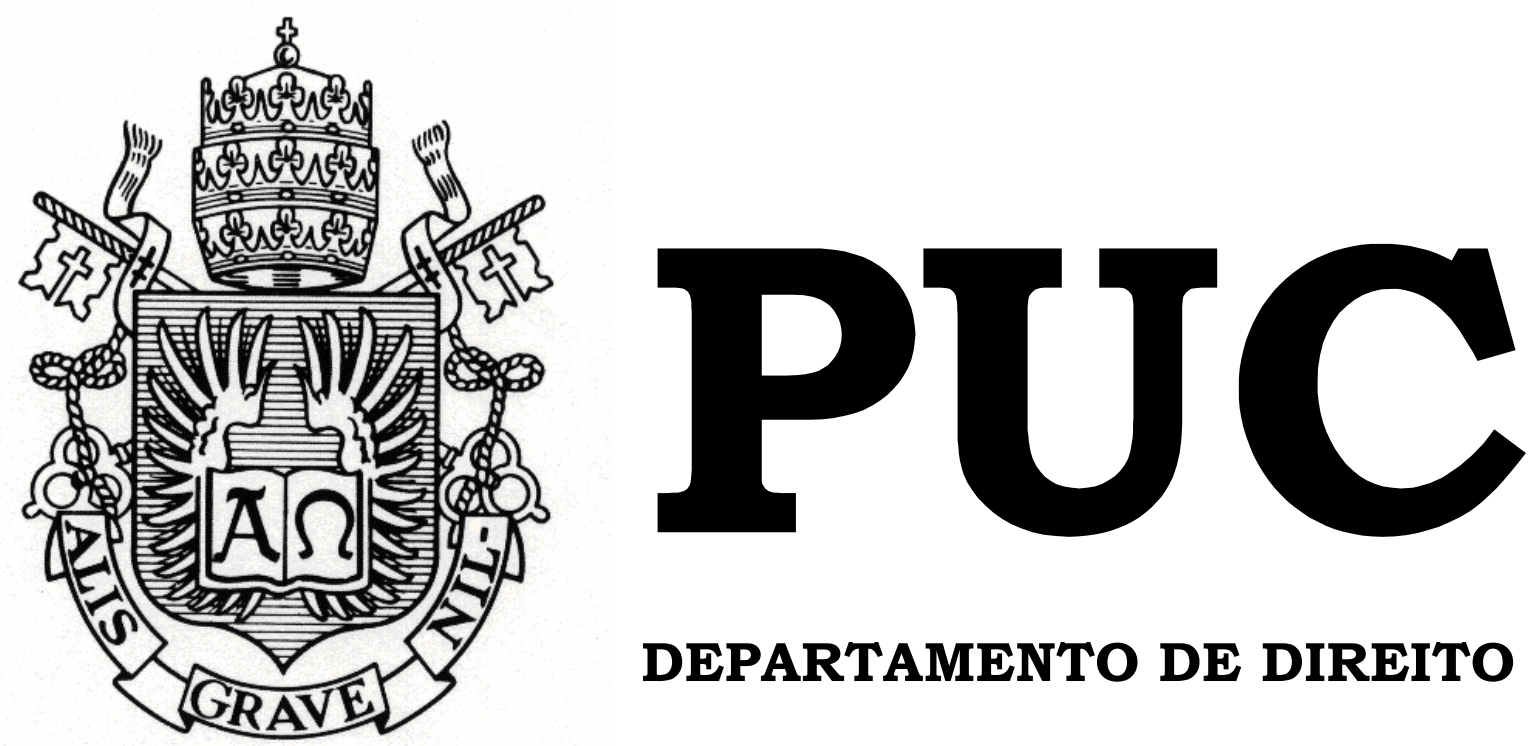

DEPARTAMENTO DE DIREITO

\title{
CÉLULAS-TRONCO EMBRIONÁRIAS E O DIREITO BRASILEIRO
}

por

RAIANA MEDEIROS DEL CASTILLO

ORIENTADORA: Kátia Regina da Costa Silva

2009.1

PONTIFÍCIA UNIVERSIDADE CATÓLICA DO RIO DE JANEIRO

RUA MARQUÊS DE SÃO VICENTE, 225 - CEP 22453-900

RIO DE JANEIRO - BRASIL 


\section{CÉlULAS-TRONCO EMBRIONÁRIAS E O DIREITO BRASILEIRO}

por

RAIANA MEDEIROS DEL CASTILLO

Monografia apresentada ao Departamento de Direito da Pontifícia Universidade Católica do Rio de Janeiro (PUC-Rio) para a obtenção do Título de Bacharel em Direito.

Orientador(a): Kátia Regina da Costa Silva 
Dedico este trabalho aos meus pais, pelo carinho, incentivo, dedicação e exemplo. 
Aos meus pais Marcia Medeiros e Rafael Del Castillo, que me apoiaram em todo o percurso da minha vida, dedicaram, cuidaram e me amaram incondicionalmente, que me deram a vida e me ensinaram a viver com dignidade e honestidade, que se doaram inteiros e abdicaram dos seus sonhos, para que muitas vezes pudesse realizar os meus.

Ao meu irmão Raoni Medeiros Del Castillo que sempre acreditou na minha vitória, que me apoiou mesmo nos momentos em que eu estava errada, que tenta resolver meus problemas antes mesmo de eu pedir e que sempre vai estar comigo.

A minha avó Astréa Medeiros, na qual me espelhei em sua felicidade, espontaneidade e sabedoria.

Aos amigos, pela simplicidade das conversas informais, pelo companheirismo nos piores e melhores momentos da minha vida, pela compreensão, pela lealdade e, sobretudo, pela amizade sincera.

Aos professores e todos aqueles que cruzaram em minha vida, participando de alguma forma na construção e realização deste tão desejado sonho de me formar. 
"A mente que se abre a uma nova idéia jamais voltará ao seu tamanho original."

Albert Einstein 


\section{RESUMO}

Este trabalho versa sobre a análise dos conceitos de bioética e biodireito utilizados na possibilidade de pesquisa visando a utilização terapêutica de células-tronco embrionárias, recentemente debatidos na Ação Direta de Inconstitucionalidade (ADI 3510), ajuizada com o propósito de impedir essa linha de estudos científicos. Expõe os principais argumentos utilizados pelos Ministros do Supremo Tribunal Federal (STF) para defender esse tipo de pesquisa e a tese central do ex-procurador-geral da República Cláudio Fonteles, que interpôs a ADI 3510.

Palavras-chave: células-tronco, embriões humanos, bioética, biodireito. 


\section{SUMÁRIO}

$\begin{array}{ll}\text { RESUMO } & 02\end{array}$

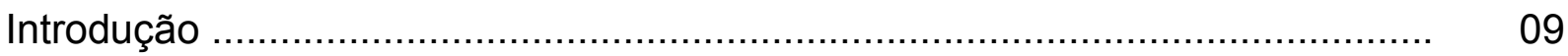

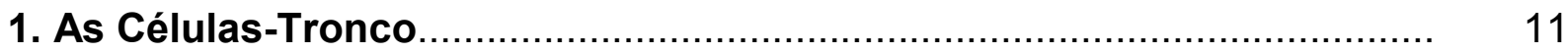

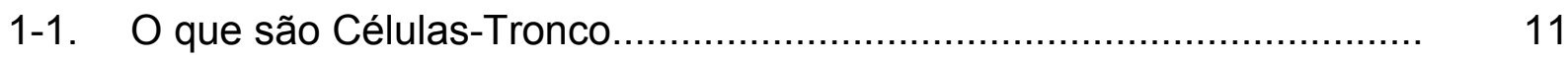

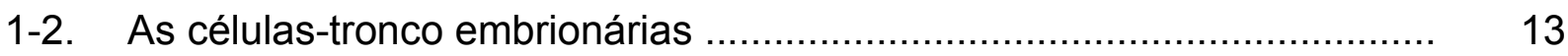

1-3. Pesquisas com células-tronco embrionárias................................... 14

2. Breve conceituação sobre Bioética e Biodireito ...................................... 17

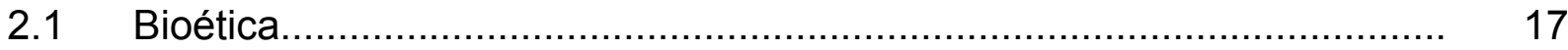

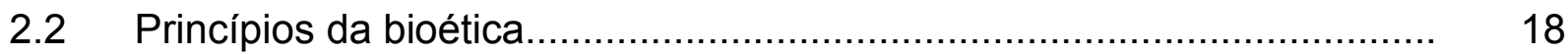

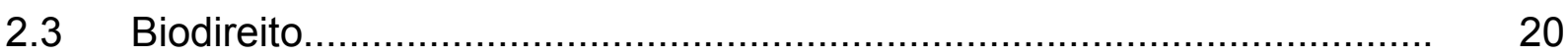

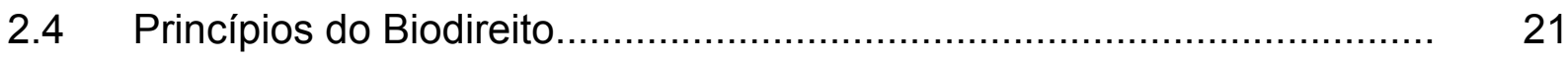

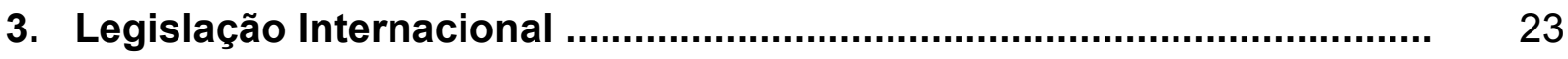

3.1. República Islâmica do Irã............................................................. 25

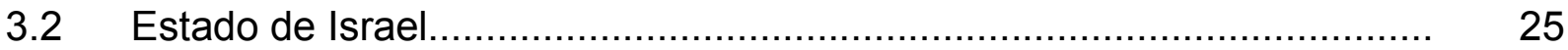

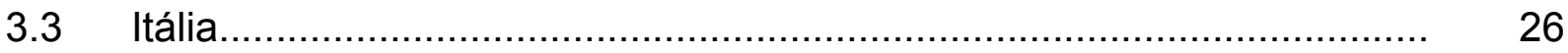

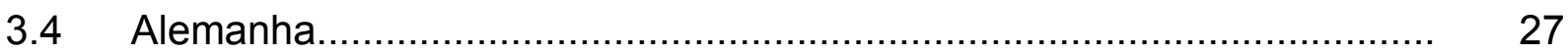

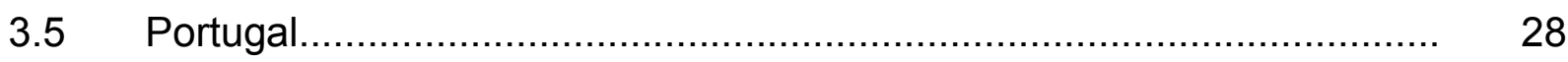

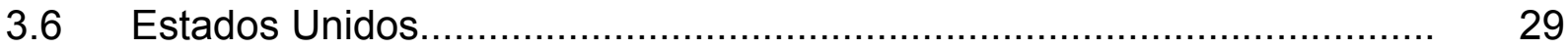

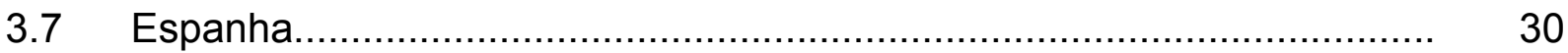

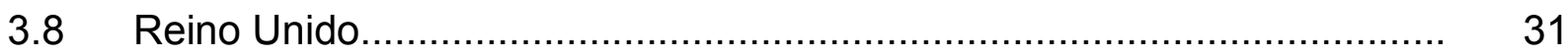

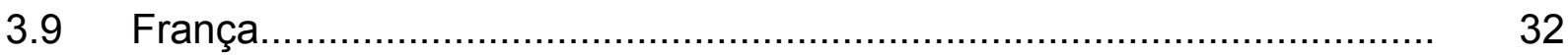

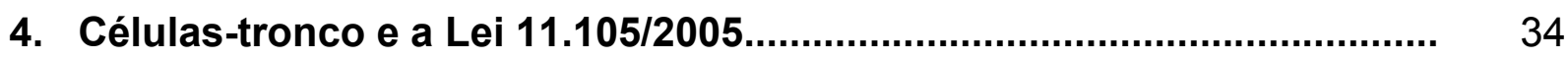

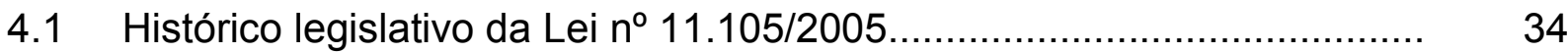


4.2 Comentários sobre a Lei $\mathrm{n}^{\circ}$ 11.105/2005 ......................................... 35

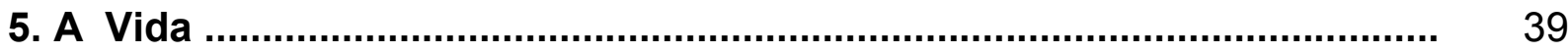

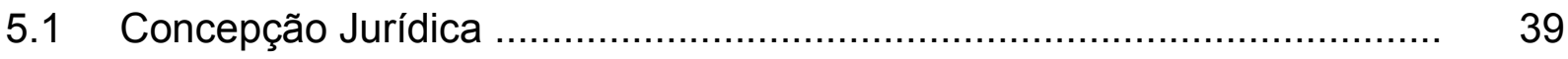

5.2 Concepção Científica .......................................................................... 41

5.3 Concepção Religiosa .................................................................... 42

5.4 Princípio da dignidade da Pessoa Humana.............................................. 43

6. Discussão sobre a legalidade do artigo $5^{\circ}$ e parágrafos da Lei 11.105/2005............................................................................................. 47

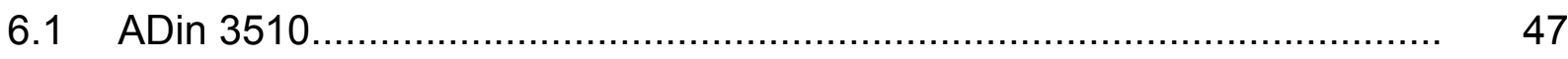

6.2 Audiência Pública................................................................................ 49

6.2.1 Bloco a favor dos dispositivos da Lei de Biossegurança.......................... 53

6.2.2 Bloco contra os dispositivos da Lei de Biossegurança............................ 57

6.3 O Julgamento............................................................................... 60

6.3.1 Voto do Ministro Carlos Ayres Britto...................................................... 65

6.3.2 Voto da Ministra Ellen Gracie.............................................................. 67

6.3.3 Voto do Ministro Menezes Direito........................................................ 68

6.3.4 Voto da Ministra Carmén Lúcia............................................................ 70

6.3.5 Voto do Ministro Ricardo Lewandowski.................................................. 71

6.3.6 Voto do Ministro Eros Grau.................................................................. 71

6.3.7 Voto do Ministro Cezar Pelluso............................................................. 72

6.3.8 Voto do Ministro Marco Aurélio................................................................. 73

6.3.9 Voto do Ministro Joaquim Barbosa...................................................... 74

6.3.10 Voto do Ministro Celso de Mello....................................................... 74

6.3.11 Voto do Ministro Gilmar Mendes........................................................... 75

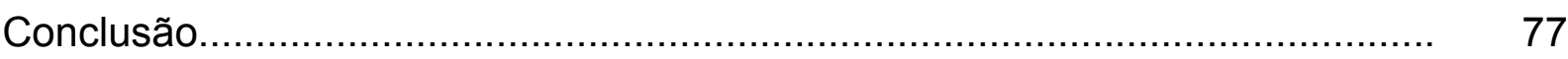


Bibliografia...

Anexo I: Anexo ao Memorial Formulado Pelo Amicus Curiae ANIS: Instituto de 85 Bioética, Direitos Humanos e Gênero em Defesa das Pesquisas com CélulasTronco Embrionárias (Constitucionalidade do Artigo $5^{\circ}$ da Lei n. 11.105/2005).

Anexo II: Lei n 11.105, de 24 de Março de 2005 104

Anexolll: Ação Direta de Inconstitucionalidade (ADI) n³510 


\section{INTRODUÇÃO}

O objetivo central desta monografia é apresentar toda a problemática e discussão que se travou no meio jurídico sobre o tema da utilização de células-tronco embrionárias em pesquisas científicas e conseqüentemente a discussão sobre o início da vida.

O método utilizado nesta monografia será a análise científica das células-tronco embrionárias, assim como a análise dos votos dos Ministros do Supremo Tribunal Federal e de análises de legislações estrangeiras.

Em 30 de maio de 2005, foi ajuizada no Supremo Tribunal Federal, pelo então Procurador-Geral da República, Claudio Fonteles, a Ação Direta de Inconstitucionalidade (ADI 3510) contra parte dos dispositivos da Lei de Biossegurança (Lei $\left.n^{0} 11.105 / 2005\right)$.

Estes dispositivos questionados permitiam a utilização de célulastronco de embriões humanos excedentes resultados das técnicas de reprodução assistida, que fossem inviáveis ou que estivessem congelados há mais de 3 (três) anos da data da publicação da lei, com o consentimento dos genitores para fins de pesquisa e terapia.

A partir dessa data travou-se um longo debate chegando até o Supremo Tribunal Federal, que envolvia vários temas relacionados ao Biodireito e Bioética, principalmente no que diz respeito ao início da vida e a dignidade da pessoa humana.

Por se tratar de um tema polêmico, que é a destruição de embriões, envolveu toda a sociedade, atingindo a política, ética, religião, direito e ciência. Confrontando posicionamentos contrários de todos esses aspectos da sociedade. 
A análise de aspectos bioéticos no uso dessas células-tronco embrionárias para pesquisas contribuem para a objetivação e desmistificação do tema.

Em todo o mundo existem milhões de embriões congelados em clínicas de reprodução assistida e grande parte deles nunca será utilizada para os fins de reprodução. A questão que surge é que ao mesmo tempo em que existe essa enorme quantidade de embriões "inviáveis", há o avanço da ciência que está buscando com a pesquisa dessas células-tronco embrionárias, o desenvolvimento da cura de doenças neuromusculares, como distrofia muscular progressiva, mal de Parkinson, diabetes e tantas outras.

A questão jurídica surge em volta dos dispositivos da Constituição Federal, quais sejam: o Art. $1^{\circ}$, inciso III, que estabelece como fundamento Constitucional a dignidade da pessoa humana e o art $5^{\circ}$, caput, que dispõe sobre a inviolabilidade do direito à vida.

Pretendo com esta monografia desvendar os aspectos polêmicos discutidos na ADIN 3510, mostrar a posição do Supremo Tribunal Federal na ADIN e o papel do direito de impor limites às pesquisas científicas sem, contudo, prejudicar o avanço da ciência. 


\section{As células-tronco}

\subsection{0 que são células-tronco}

As células-tronco são tipos de células indiferenciadas, sem função específica nos tecidos, capazes de multiplicar-se mantendo-se indiferenciadas por longos períodos (tanto in vitro como in vivo), mas que diante de estímulos específicos podem diferenciar-se em células maduras e funcionais dos tecidos. As células-tronco têm a propriedade fundamental de divisão assimétrica, ou seja, ao mesmo tempo que originam células precursoras com capacidade de diferenciação restrita a um determinado tecido, produzem células indiferenciadas que repõem a população de células-trono. ${ }^{1}$

De acordo com Marco Antonio Zago, o que difere as células-tronco das demais células do organismo é que são células indiferenciadas e nãoespecializadas, com capacidade de se multiplicar por longos períodos mantendo-se indiferenciadas e são também capazes de se diferenciar em células especializadas de um tecido particular. ${ }^{2}$

Existem vários tipos de células-tronco. O potencial das célulastronco especifica a sua capacidade de diferenciação. As totipotentes podem produzir todas as células embrionárias e extra embrionárias, é o óvulo fertilizado ou zigoto, capaz de gerar um organismo inteiro, inclusive a placenta e anexos embrionários; as pluripotentes podem produzir todos os tipos celulares do embrião, conseguem se diferenciar em todos os tecidos do corpo humano, como as células tronco embrionárias; as multipotentes

\footnotetext{
${ }^{1}$ ZAGO, Marco Antônio; COVAS, Tadeu Dimas. Células-Tronco: A Nova Fronteira da Medicina. São Paulo: Atheneu, 2006.p.19

${ }^{2}$ ZAGO, Marco Antônio; COVAS, Tadeu Dimas. Células-Tronco: A Nova Fronteira da Medicina. São Paulo: Atheneu, 2006.p.4
} 
podem produzir células de várias linhagens; as oligopotentes podem produzir células dentro de uma única linhagem e as unipotentes produzem somente um único tipo celular maduro. As células-tronco embrionárias são consideradas pluripotentes porque uma célula pode contribuir para formação de todas as células e tecidos no organismo. ${ }^{3}$

As células-tronco totipotentes são encontradas somente nos embriões. São aquelas presentes nas primeiras fases da divisão, quando o embrião tem até 16-32 células (até três ou quatro dias de vida).

As pluripotentes surgem quando o embrião atinge a fase de blastocisto (a partir de 32-64 células, aproximadamente, a partir do $5^{\circ}$ dia de vida). As células internas do blastocisto são pluripotentes, enquanto as células da membrana externa do blastocisto destinam-se a produzir a placenta e as membranas embrionárias. Supõe-se que algumas células pluripotentes permanecem nos tecidos até a fase adulta, com a função de regenerá-los.

As células-tronco multipotentes são aquelas encontradas nos tecidos adultos (medula óssea, cérebro, fígado, coração, etc) ou no sangue do cordão umbilical. ${ }^{4}$

As células-tronco pluripotentes se diferenciam em célulasmultipotentes, isto é, células de um tecido ou órgão especializado dão origem a todas as células deste tecido e a nenhuma célula de outro tecido. Por exemplo, as células multipotentes do sangue dão origem a células de glóbulos vermelhos , plaquetas e glóbulos brancos. ${ }^{5}$

\footnotetext{
${ }^{3}$ VIEIRA, Alexandra.Células-tronco: o que são e para que servem. Disponível em < http://noticias.terra.com.br/ciencia/interna/0,OI472268-EI1434,00.html> . Acesso em 19 mar. 2009.

${ }^{4}$ INSTITUTO CELULAR DE CARDIOLOGIA.Terapia Celular. Disponível em < http://www.incl.rj.saude.gov.br/incl/celula-tronco/index.asp>. Acesso em 29 abr.2009.

${ }_{5}^{5}$ BARTH, Wilmar Luiz.CélulasTtronco e Bioética: O Progresso Biomédico e os Desafios Éticos. Porto Alegre: Edipucrs, 2006.p.31.
} 


\subsection{As Células-tronco Embrionárias}

As células-tronco embrionárias são:

“ uma classe especial de CT derivadas de embriões mamíferos no estágio de blastocisto. Nesse estágio, células da massa celular interna, que vão dar origem a todos os tecidos do indivíduo adulto, ainda não se diferenciaram e podem ser colocadas em cultura de forma a estabelecer uma linhagem celular pluripotente - uma linhagem de células-tronco embrionárias. A capacidade dessas células de se multiplicar em cultura sem perder a pluripotência, assim como a possibilidade de induzir sua diferenciação em tipos celulares específicos, tornou as $\mathrm{CT}$ embrionárias uma poderosa ferramenta de pesquisa e uma promissora fonte de tecidos para transplante."

A diferença entre células-tronco embrionárias e células-tronco adultas é que as células-tronco embrionárias são células primitivas indiferenciadas de embrião que têm potencial para se tornarem uma variedade de tipos celulares especializados de qualquer órgão ou tecido do organismo. Já as células-tronco adultas (multipotentes) são células indiferenciadas encontradas em um tecido diferenciado, que podem renovar-se, e com certa limitação, diferenciar-se para produzirem os tipos de células especializadas dos tecidos dos quais se origina, como tecidos da medula óssea, fígado, polpa de dente e do cordão umbilical.

As células-tronco adultas (CTA) mais facilmente disponíveis e comumente utilizadas nas clínicas de fertilização são as células-tronco hematopoéticas, cujas principais fontes são a medula óssea e o sangue de cordão umbilical. As células-tronco embrionárias (CTE) são definidas por sua origem, e são derivadas do estágio do blastocisto do embrião. A célulatronco embrionária é normalmente utilizada, em alguns países, a partir dos blastocistos gerados em clínicas de fertilização, onde o casal doa, para a

\footnotetext{
${ }^{6}$ ZAGO, Marco Antônio; COVAS, Tadeu Dimas. Células-Tronco: A Nova Fronteira da Medicina. São Paulo: Atheneu, 2006.p.21)
} 
pesquisa com fins terapêuticos, os blastocistos não utilizados na fertilização in vitro.

\title{
1.3 Pesquisa com Células-tronco Embrionárias
}

As novas pesquisas com células-tronco, ou também denominadas de células-mãe ou ainda células estaminais, têm despertado um grande debate. O primeiro relato de pesquisa em células tronco utilizando células embrionárias humanas foi publicado em 1998 pela equipe do Prof. James A. Thomson, da Universidade de Wisconsin/EUA. ${ }^{7}$

Neste mesmo ano, a equipe do Prof. John D. Gearhart, da Universidade John Hopkins, realizou pesquisas com células-tronco fetais humanas.

Segundo a opinião de Ricardo Ribeiro dos Santos, médico, Pesquisador Titular da Fundação Oswaldo Cruz/Ministério da Saúde:

\begin{abstract}
"Os estudos até então realizados utilizaram células-tronco de adultos, retiradas do próprio paciente. Embora os resultados sejam encorajadores, a baixa capacidade de diferenciação destas células indica que provavelmente esta não será uma alternativa eficaz para o reparo de todas as doenças. Em especial, no caso de doenças decorrentes de defeitos genéticos, a aplicação das células do próprio paciente não trará nenhum benefício, uma vez que estas carregarão também o mesmo defeito genético. A massa celular indiferenciada do embrião em seus estágios iniciais dá origem a células dos vários tecidos e órgãos, o que evidencia, sem nenhuma dúvida, a pluripotencialidade das células-tronco embrionárias ali presentes. A partir da massa interna de embriões em fase de blastocisto, linhagens de células indiferenciadas podem ser obtidas. Através de técnicas de cultura de células, estas podem se replicar e se manter indiferenciadas ou diferenciarem-se em vários tipos celulares, de acordo com as condições de cultivo. Portanto, estas células seriam potencialmente as candidatas ideais para a regeneração de tecidos lesados. Além disso, o estudo destas células permitirá ainda o aprendizado dos processos de diferenciação celular, o que poderá ainda contribuir para a ampliação da nossa capacidade de utilização de célulastronco adultas em terapia celular. A importância das pesquisas com células-tronco embrionárias é tão evidente que cientistas em países
\end{abstract}

\footnotetext{
${ }^{7}$ Ibid.p.26
} 
desenvolvidos, tais como os Estados Unidos e a Inglaterra, já desenvolvem há anos investigações sobre as propriedades biológicas e terapêuticas das células-tronco embrionárias. Cientistas do Brasil têm hoje a oportunidade de fazer parte desta comunidade científica que trabalha na fronteira do desenvolvimento tecnológico que, sem dúvida, poderá trazer grandes benefícios para a população mundial na área de saúde. ."

Cientistas acreditam que no futuro as células-tronco possam ser empregadas na cura de diversas doenças como, por exemplo, mal de Alzheimer, leucemia, mal de Parkinson e até mesmo diabetes. Através do método da clonagem terapêutica, várias lesões e doenças degenerativas e síndromes diversas (como as mucopolisacaridoses) seriam resolvidas. Todas elas constituem doenças graves, que causam grande sofrimento a seus portadores.

Dados estatísticos demonstram que, no Brasil, entre 10 a 15 milhões de pessoas têm diabetes e que $3 \%$ a $5 \%$ da população têm doenças genéticas que podem ser congênitas ou ter início na infância ou na idade adulta. Além de surgirem entre 8.000 e 10.000 novos casos de lesão medular por ano (paraplegia ou tetraplegia). ${ }^{9}$

O mal de Parkinson e o diabetes melino juvenil são resultados da morte e disfunção de um ou alguns tipos celulares. A reposição dessas células por tecidos produzidos a partir das células-tronco embrionárias humanas, segundo Marco Antonio Zago e Dimas Tadeu Covas, poderia em tese proporcionar uma terapia duradoura. ${ }^{10}$

\footnotetext{
${ }^{8}$ SANTOS,Ricardo Ribeiro dos Santos; SOARES, Milena Botelho Pereira. A importância da utilização de células-tronco embrionárias e o direito de doação de embriões. Disponível em $<\mathrm{http}: / /$ www.ghente.org/temas/celulas-tronco/ricardo_ribeiro_e_milena.pdf $>$ Acesso em 16 mar. 2009.

9 BARROSO, Luiz Roberto.Pedido de ingresso como amicus curiae. Disponível em<http://www.lrbarroso.com.br/pt/noticias/minuta_amicus_curiae_lrb_30set05.pdf $>$ Acesso em 19 mar.2009.

10 ZAGO, Marco Antônio; COVAS, Tadeu Dimas. Células-Tronco: A Nova Fronteira da Medicina. São Paulo: Atheneu, 2006.p.27
} 
Tecidos, músculos, nervos e até mesmo órgãos poderão, em breve, ser reconstituídos com a aplicação deste tipo de tratamento, combatendo diversas doenças crônicas, como acredita a comunidade científica.

\begin{abstract}
"Até 2005, as CT embrionárias humanas já foram diferenciadas in vitro em uma variedade de tipos celulares derivados dos três folhetos embrionários e também em células germinativas. CT embrionárias humanas em cultura podem formar neurônios e pele (ectoderma); sangue, músculo, cartilagem, células endoteliais e cardíacas (mesoderma); células pancreáticas (endoderma), entre outras. Assim, as CT embrionárias humanas apresentam um grande potencial em medicina regenerativa, tanto como fonte de tecidos para transplante, quanto como um modelo para o estudo da embriogênese humana.
\end{abstract}

Porém, para que seja cumprida toda a promessa terapêutica das CT embrionárias, alguns obstáculos importantes devem ser superados. Um deles diz respeito ao risco das células derivadas das CT embrionárias virem a formar tumores in vivo. De fato, quando injetadas em camundongos imunossuprimidos SCID, as CT embrionárias indiferenciadas formam teratomas. No entanto, os experimentos direcionados à utilização dessas células como fonte de tecidos para terapia utilizam sempre para transplante $\mathrm{CT}$ diferenciadas in vitro. Apesar de sempre haver o risco de algumas células não diferenciadas restarem na população diferenciada, nos diversos estudos já publicados não foi detectada a formação de tumores a partir das CT embrionárias diferenciadas. Mesmo assim, deve-se sempre levar em conta esse risco, devendo ser desenvolvido protocolos seguros de diferenciação de CT embrionárias antes de terapias com essas células serem experimentadas em seres humanos.

Além disso, é necessário o desenvolvimento de um modelo animal mais próximo ao ser humano para seres in vivo que avaliem a eficácia e segurança das terapias baseadas em CT embrionárias de macaco rhesus poderá transformar este animal num modelo adequado para esses estudos.

Outras questões que precisam ser resolvidas antes de utilizarmos as CT embrionárias em humanos dizem respeito às instabilidades cromossômicas observadas nestas células após longo tempo de cultura e à presença de contaminações derivadas de produtos de origem animal utilizados no estabelecimento e cultivo das CT embrionárias humanas. Porém com os rápidos avanços nas pesquisas com estas células, novos protocolos já foram propostos para solucionar tais questões." 11

${ }^{11}$ ZAGO, Marco Antônio; COVAS, Tadeu Dimas. Células-Tronco: A Nova Fronteira da Medicina. São Paulo: Atheneu, 2006.p.27 e 28 


\section{Breve conceituação sobre Bioética e Biodireito}

\subsection{Bioética}

Segundo a enciclopéia da Bioética, a bioética é um neologismo derivado das palavras gregas "bios" que significa vida, e "ethike", que significa ética. A definição pode ser dada como o estudo sistemático das dimensões morais - incluindo visão, decisão, conduta e normas morais das ciências da vida e do cuidado da saúde, utilizando uma variedade de metodologias éticas num contexto interdisciplinar. ${ }^{12}$

Já segundo a UNESCO, o termo bioética diz respeito ao campo de estudo sistemático, plural e interdisciplinar, envolvendo questões morais teóricas e práticas, levantadas pela medicina e ciências da vida, enquanto aplicadas aos seres humanos e à relação destes com a biosfera.

Foi Van Rensselaer Potter, na Universidade de Wisconsin, quem usou pela primeira vez o termo bioethics (bioética) ao escrever em 1971, o livro Bioehtics: bridges to the future. Porém ele usou a palavra num sentido evolutivo muito distante do significado que ela tem hoje. Segundo Potter : “ o objetivo desta disciplina, seria ajudar a humanidade em direção a uma participação racional, mas cautelosa, no processo da evolução biológica e cultural."

\footnotetext{
${ }^{12}$ PESSINI, Leo; BARCHIFONTAINE, Christian de Paul. Problemas atuais de Bioética.São Paulo: Edições Loyola, 2008. p 31
} 
Ele escolheu o termo "bio" por representar o conhecimento biológico, a ciência dos sistemas viventes, e "ética" por representar o sistema de valores humanos. Entretanto foi Andre Helleger, na Universidade de Georgetown, quem primeiro usou o termo num contexto institucional para designar a área de pesquisa ou campo de aprendizagem que hoje é utilizada. ${ }^{13}$

O termo bioética em sua concepção alargada passou a designar os problemas éticos gerados pelos avanços nas ciências biológicas e médicas. Problemas que se evidenciam com o poder do homem interferir de forma eficaz nos processos de nascimento e morte. ${ }^{14}$

\subsection{Princípios da Bioética ${ }^{15}$}

Em 1974 o Congresso Norte-Americano constituiu a Comissão Nacional para a Proteção dos Seres Humanos da Pesquisa Biomédica e Comportamental, com o objetivo de levar a cabo uma pesquisa e um estudo completo que identificassem os princípios éticos básicos que deveriam nortear a experimentação em seres humanos nas ciências do comportamento e na biomedicina.

Esta Comissão demorou quatro anos para publicar o que passou a ser conhecido como relatório Belmont. Foi proposto um método, baseado na aceitação de que três princípios éticos mais globais deveriam prover as bases sobre as quais formular, criticar e interpretar algumas regras específicas. A comissão reconheceu que outros princípios poderiam também ser relevantes, porém três foram identificados como principais.

\footnotetext{
13 Ibid. p.32

14 BARBOSA, Heloísa Helena. Princípios do Biodireito. Disponível em $<$ http://www.espdh.hpg.com.br/texto7.pdf> Acesso em 30 mar. 2009.

${ }^{15}$ PESSINI, Leo; BARCHIFONTAINE, Christian de Paul. Op. Cit., PP.76/80.
} 
O relatório Belmont foi oficialmente promulgado em 1978 e tornouse a declaração principialista clássica.

Os três princípios são: respeito pelas pessoas (autonomia), beneficência e justiça.

O respeito pelas pessoas incorpora no mínimo duas convicções éticas. $\mathrm{O}$ de que as pessoas deveriam ser tratadas com autonomia e de que as pessoas cuja autonomia está diminuída devem ser protegidas. Pessoa autônoma seria o indivíduo capaz de deliberar sobre seus objetivos pessoais e agir sob a orientação dessa deliberação. Não pode haver coação externa e deve ser entendida num sentido muito concreto. A ação é considerada autônoma quando passa pelo consentimento informado.

Desse princípio decorrem procedimentos práticos, como a exigência do consentimento informado e de como tomar decisões de substituição, quando uma pessoa for incapaz.

O princípio da beneficência não considera a beneficência no sentido clássico, como caridade, e sim a considera como uma obrigação. Nesse sentido foram formuladas duas regras, a de não causar dano e a de maximizar os benefícios e minimizar os possíveis riscos.

O princípio de justiça é a imparcialidade na distribuição dos riscos e benefícios. Outra maneira de entender o princípio de justiça é dizer que "os iguais devem ser tratados igualmente". O problema está em dizer quem são os iguais. O relatório Belmont não deixou claro essa questão. 


\subsection{Biodireito}

Apesar de existir corrente que nega a existência do Biodireito, este pode ser entendido num primeiro momento como um ramo do Direito que trata da teoria, da legislação e da jurisprudência relativas às normas reguladoras da conduta humana em face dos avanços da Biologia, da Biotecnologia e da Medicina ${ }^{16}$

$\mathrm{O}$ rápido desenrolar dos acontecimentos científicos exige do jurista um esforço interpretativo para adequar as normas existentes às novas situações. Além disso, salienta Heloísa Helena Barbosa, a regulamentação de determinadas situações colocará, certamente, em discussão problemas que ela não resolverá: a criação de um estatuto sobre o embrião implicará em debates envolvendo o momento de início da vida, a existência ou não do direito a se ter um filho, e mesmo o aborto.

"Não basta ao Direito adaptar as categorias jurídicas existentes ou
formular novas regras para apreender as novas técnicas e relações
interpessoais decorrentes, pois isto seria colocar o Direito à reboque da
ciência, subvertendo ou desconhecendo sua natureza científica dotada de
princípios, métodos e formulações próprios. Observe-se que ainda que
um imperativo deontológico fosse reconhecido e rigorosamente
respeitado pelos profissionais, problemas estritamente jurídicos não
seriam resolvidos, como os relativos à filiação, o acesso a determinadas
informações, a disponibilidade do corpo. Não é suficiente, portanto, a
existência de regras. O Direito não é somente um conjunto de regras, de
categorias, de técnicas: ele veicula também um certo número de valores.
Por conseguinte, se o Direito deve evoluir para dar conta dos progressos
científicos e assim se adaptar aos avanços médicos que permitem mudar a
vida e não apenas prolongá-la, deve necessariamente ordenar essas
intervenções sobre o homem. O sistema jurídico é feito de regras que
constróem uma sociedade fundada em certos valores, tais como a
liberdade ou a igualdade que geram uma concepção de homem. O Direito
é a regra que uma sociedade se dá. As intervenções sobre o corpo
humano, como as técnicas de reprodução assistida, as manipulações
genéticas, as experimentações em humanos, os transplantes e clonagem,
conduzem automaticamente a uma reificação do ser humano, se mantidas
determinadas categorias clássicas do Direito. O estabelecimento de regras
sobre esses fatos poderá manter esse entendimento ou definir novas
categorias, ou adaptar as existentes de modo a assegurar a permanência
do primado da pessoa humana, pedra-de-toque de nossa civilização

${ }^{16}$ BARBOZA, Heloísa Helena. Op. Cit., p. 212 
jurídica, sobre toda visão reducionista que faz com que se perca sua singularidade absoluta." 17

\subsection{Princípios do Biodireito}

O encontro entre o Direito e a Ética se dá, em primeiro lugar, na Constituição, onde os valores morais se convertem em princípios jurídicos. A partir daí se irradiam pelo sistema normativo, condicionando a interpretação e a aplicação de todo o direito infraconstitucional. ${ }^{18}$

Se for certo que a recepção nos textos constitucionais de uma série de valores fundamentais, como a vida, a dignidade humana, a liberdade e a solidariedade e sua proteção enquanto direitos tornou-os pedras angulares da Bioética moderna, não menos certo é dizer-se que esses direitos devem constituir, por tal razão e, principalmente, por terem natureza jurídica, a rede estrutural do Biodireito. Sendo assim os princípios constitucionais devem constituir os princípios do biodireito.

"Como qualquer norma jurídica, a disciplina das matérias que se possam classificar como integrantes do Biodireito deve ser harmônica com o ordenamento, acorde com seus cânones. Nesse sentido, o princípio do respeito à dignidade humana, fundamento da República, é basilar para toda e qualquer norma jurídica. Mas não só esse deve ser observado, já que, concomitantemente, outros se impõem. Assim, a regulamentação sobre transplantes de órgãos encontrou limitação no art. $199, \S 4^{\circ}$, da Constituição, que vedou todo tipo de comercialização. Nessa linha, a Lei de Biossegurança (Lei ${ }^{\circ}$ 8.974/95) se ateve aos ditames do art. 225, $\S 1^{\circ}$, II e $\mathrm{V}$, estabelecendo normas destinadas a preservar a diversidade e a integridade do patrimônio genético do país e a fiscalizar as entidades

\footnotetext{
${ }^{17}$ BARBOZA, Heloísa Helena. Op. Cit., p.213/214.

${ }^{18}$ BARROSO, Luís Roberto. A Defesa da Constitucionalidade das Pesquisas comCcélulas-Tronco embrionárias.Disponível em<http://www.idp.org.br/index.php?op=stub\&id=9\&sc_1=60>. Acesso em 30 mar.2009.
} 
dedicadas à pesquisa e manipulação de material genético, normas essas que acabaram por proibir a manipulação genética de células germinais humanas, impedindo assim a clonagem de seres humanos no Brasil."19

${ }^{19}$ BARBOZA, Heloísa Helena. Op. Cit., p.214. 


\section{A Legislação Internacional ${ }^{20}$}

Em 26 de maio de 2008, Ministros do Supremo Tribunal Federal (STF) receberam um documento do Instituto de Bioética, Direitos Humanos e Gênero (Anis) favorável às pesquisas com células-tronco embrionárias. O Instituto foi admitido como amicus curie (amigo da Corte) na Ação Direta de Inconstitucionalidade 3510, que discute o tema.

Esse documento compreende informações que complementaram o memorial apresentado em 20 de abril de 2007 (ANEXO I).

O estudo "Pesquisa com células-tronco embrionárias: 25 países" foi financiado pelo Ministério da Saúde e elaborado por uma equipe coordenada pela pesquisadora Debora Diniz. O documento é composto por 21 páginas que reúnem as leis e as normas de 25 países, dos quais apenas um, a Itália, proíbe pesquisas com células-tronco embrionárias. ${ }^{21}$

Os cinco continentes estão representados no documento, que contém informações dos seguintes países: Canadá, Comunidade da Austrália, Confederação Suíça, Coréia, Estado de Israel, Estados Unidos da América, Estados Unidos Mexicanos, Federação Russa, Japão, Reino da Dinamarca, Reino da Espanha, Reino da Noruega, Reino da Suécia, Reino dos Países Baixos, Reino Unido da Grã-Bretanha e Irlanda do Norte, República da

\footnotetext{
${ }^{20}$ BRAGA, Kátia Soares; DINIZ, Débora. Anexo ao Memorial formulado pelo amicus curiae: ANIS: Instituto de Bioética, Direitos Humanos e Gênero. Disponível em: < http://www.ccr.org.br/uploads/noticias/adi_3510_memorial_anis_2.pdf $>$. Acesso em $23 \mathrm{mar}$. 2009.

${ }^{21}$ Notícias STF, disponível em

$<$ http://www.stf.jus.br/portal/cms/verNoticiaDetalhe.asp?idConteudo=89480\&caixaBusca=N $>$. Acesso em 23 mar.2009.
} 
África do Sul, República da Finlândia, República da França, República da Índia, República de Cingapura, República de Portugal, República Federal da Alemanha, República Islâmica do Irã, República Italiana e República Popular da China.

Para a advogada da Anis, Gabriela Rollemberg, o estudo, que comporta legislação comparada, demonstra uma tendência internacional favorável à autorização das pesquisas. "O Brasil está seguindo o contexto internacional, uma tendência mundial de permissão das pesquisas", disse a advogada.

A tendência internacional de autorizar a pesquisa com células-tronco embrionárias deve ser entendida não apenas como uma aposta dos Estados democráticos no progresso da ciência, mas principalmente como uma afirmação ética da soberania do princípio da liberdade de pesquisa para a promoção do conhecimento como um bem público. ${ }^{22}$

A maioria dos 25 países que foram objeto da análise do estudo acima mencionado são nações democráticas e laicas, com desenvolvimento científico, médico e tecnológico equivalente ou superior ao brasileiro. ${ }^{23}$

O que se verificou nessa pesquisa é que há um importante consenso ético nas legislações e regulamentações dos países analisados, que é o reconhecimento de que embriões congelados e remanescentes das clínicas de reprodução humana assistida só podem ser utilizados nas pesquisas científicas se houver o consentimento dos genitores. Esta garantia ética também está presente na lei brasileira.O que também se verificou é que

\footnotetext{
${ }^{22}$ DINIZ, Debora. Em Benefício da Coletividade - Células-Tronco. O Estado de S. Paulo, São Paulo, 14 out. 2007. Caderno Aliás, p. 3.

${ }^{23}$ BRAGA, Kátia Soares; DINIZ, Débora. Anexo ao Memorial formulado pelo amicus curiae: ANIS: Instituto de Bioética, Direitos Humanos e Gênero. Disponível em: <

http://www.ccr.org.br/uploads/noticias/adi_3510_memorial_anis_2.pdf>. Acesso em 23 mar. 2009.p 5.
} 
grande parte das legislações proíbe a comercialização de embriões. Apenas a Alemanha autoriza o comércio de linhagens de células-tronco embrionárias de outros países.

A seguir, irei abortar mais especificamente alguns países objeto do estudo acima mencionado.

\subsection{República Islâmica do Irã}

A República Islâmica do Irã merece destaque, já que se trata de um país organizado por confissão religiosa, que autoriza a pesquisa com células-tronco embrionárias.

As pesquisas com células-tronco embrionárias vêm sendo conduzidas a partir de fatwas (posicionamentos religiosos que autorizam ou não uma ação) favoráveis. A abertura do debate iraniano se deu com a mudança da lei de aborto, em $2003 .^{24}$

\subsection{Estado de $\left.||^{2} r a e\right|^{25}$}

Israel não é um país laico como o Brasil, suas fundamentações para suas decisões políticas são pautadas em valores religiosos.

O tema das pesquisas com células-tronco embrionárias esteve na pauta de discussões legais do país há quase uma década.

\footnotetext{
${ }^{24}$ BRAGA, Kátia Soares; DINIZ, Débora. Anexo ao Memorial formulado pelo amicus curiae: ANIS: Instituto de Bioética, Direitos Humanos e Gênero. Disponível em: < http://www.ccr.org.br/uploads/noticias/adi_3510_memorial_anis_2.pdf $>$. Acesso em 23 mar. 2009.p 6.

${ }^{25}$ IBID.p 7.
} 
Após um pedido de moratória às pesquisas com embriões humanos em 1999, o Comitê Consultivo de Bioética propôs a abertura das pesquisas em 2001, amparado em dois argumentos centrais à tradição judaica.

O primeiro é pautado no fato de que o status moral de um embrião congelado é comparável ao de gametas, portanto, não há qualquer ameaça à dignidade humana em sua manipulação para fins científicos. Já o segundo é o argumento de que se vê grande valor nas tentativas científicas de cura e tratamento para doenças, por isso a posição marcadamente favorável às pesquisas genéticas no país, inclusive a clonagem terapêutica.

\subsection{Itália ${ }^{26}$}

A Itália é a única entre os 25 países que foram objeto do estudo "Pesquisa com células-tronco embrionárias: 25 países", e que possui capacidade tecnológica e estrutura científica compatível com a brasileira, que proíbe a pesquisa com células-tronco embrionárias.

O tema de pesquisas com células-tronco embrionárias na legislação italiana está inserido em uma lei que trata da reprodução humana assistida datada de 2004. O objetivo da lei é controlar o acesso às tecnologias reprodutivas, impedindo novas formas de constituição de família.

O documento referido, aponta uma possível explicação para a singularidade da lei Italiana, que seria a influência da Igreja Católica nas decisões do Estado. Os cientistas que defenderam o uso de células-tronco para a realização de pesquisas, sofreram ameaças de excomunhão.

A Lei proíbe qualquer experimento com embrião humano, assim como congelar e destruir embriões. A pesquisa clínica e experimental com

\footnotetext{
${ }^{26}$ Ibid. p 6 .
} 
embriões é permitida apenas para finalidades terapêuticas e diagnósticas dirigidas à saúde do próprio embrião, desde que não estejam disponíveis metodologias alternativas. $\mathrm{Na}$ Itália existe um órgão regulador que é o Instituto Superior de Saúde. ${ }^{27}$

\subsection{Alemanha ${ }^{282930}$}

$\mathrm{Na}$ Alemanha a pesquisa com células-tronco embrionárias foi regulamentada por lei em 2002.Existindo um órgão regulador que avalia os protocolos de pesquisas com células-tronco denominado de Comissão Central de ética para pesquisas de Células-Tronco. Essa lei permite a pesquisa com células-tronco, porém é proibido o uso de embriões alemães. Assim só é possível a realização de pesquisas com células-tronco de embriões importados de outros países.

A permissão para a importação de células-tronco foi dada pela Câmara Baixa do Parlamento Alemão ( Buntestag ), tornando possível importar células criadas antes de 2007, já que anteriormente só era permitido até primeiro de janeiro de 2002.

A nova data ampliou as opções dos cientistas alemães, que passaram a ter acesso a aproximadamente 500 novas linhas de células-tronco embrionárias criadas em laboratórios do exterior antes de $1^{\circ}$ de maio de

\footnotetext{
${ }^{27}$ GRAIEB, Carlos. STF e a decisão: pesquisas com células-tronco é constitucional. Disponível em $<$ http://arquivoetc.blogspot.com/2008/05/stf-deciso-pesquisa-com-clulas-tronco.html $>$ Acesso em 23 mar.2009.

${ }^{28}$ O ESTADO DE SÃO PAULO. Alemanha aprova lei que Facilita Pesquisa com CélulasTronco. Disponível em http://www.dw-world.de/dw/article/0,,3261145,00.html >Acesso em 24 marc. 2009.

${ }^{29}$ GRAIEB, Carlos. STF e a decisão: pesquisas com células-tronco é constitucional. Disponível em < http://arquivoetc.blogspot.com/2008/05/stf-deciso-pesquisa-com-clulas-tronco.html > Acesso em 23 mar.2009.

${ }^{30}$ BRAGA, Kátia Soares; DINIZ, Débora. Anexo ao Memorial formulado pelo amicus curiae: ANIS: Instituto de Bioética, Direitos Humanos e Gênero. Disponível em: < http://www.ccr.org.br/uploads/noticias/adi_3510_memorial_anis_2.pdf $>$. Acesso em 23 mar. 2009.p 12.
} 
2007. Antes da alteração da lei, os cientistas alemães só tinham acesso a pouco mais de 20 linhas de células-tronco embrionárias.

Essa restrição quanto ao uso de células-tronco embrionárias de origem alemã combinado com o marco legal restritivo gerou várias críticas, sendo alvo de várias discussões internacionais no campo da bioética. Entende-se que a história do nazismo dificulta o debate democrático e razoável na Alemanha, por isso o uso de material genético importado e a proibição do uso do material genético Alemão.

\subsection{Portugal ${ }^{31}$}

Atualmente, não há legislação específica sobre clonagem humana, uso de células-tronco ou reprodução assistida em Portugal. ${ }^{32}$

Portugal apresenta uma situação diferente do contexto da União Européia. Apesar de não possuir um marco legal específico que regulamente a pesquisa com células-tronco, pareceres do Conselho Nacional de Ética para as Ciências da Vida (CNECV) vêm assumindo um papel regulador da prática científica em Portugal.

O parecer $n^{\circ} 44$, sobre a Procriação Medicamente Assistida, afirma que, se o destino de embriões remanescentes de fertilização in vitro for o descarte, eles poderão ser utilizados para fins científicos.

\footnotetext{
${ }^{31}$ BRAGA, Kátia Soares; DINIZ, Débora. Anexo ao Memorial formulado pelo amicus curiae: ANIS: Instituto de Bioética, Direitos Humanos e Gênero. Disponível em: < http://www.ccr.org.br/uploads/noticias/adi_3510_memorial_anis_2.pdf $>$. Acesso em 23 mar. 2009.p 13.

32 AGENCIA LUSA. Conselho de ética português da sinal amarelo à clonagem. Disponível em <lhttp://www.agencialusa.com.br/index.php?iden=873>. Acesso em 24 ma.2009.
} 
Portanto a pesquisa com células-tronco embrionárias pode ser realizada em Portugal com o amparo dos pareceres desse Conselho de Ética.

\subsection{Estados Unidos ${ }^{333435}$}

A pesquisa com células-tronco é autorizada nos estados Unidos, porém não há lei específica sobre o assunto, há, tão somente, leis específicas que regulam o financiamento de pesquisas. Os órgãos reguladores que avaliam os protocolos de pesquisa são os Institutos Nacionais de Saúde.

No governo do presidente George W. Bush, até 2001, a pesquisa com células-tronco era autorizada desde que não contasse com o financiamento federal. Em 2001 uma lei permitiu a pesquisa financiada por recursos federais com linhagens de células-tronco já existentes, ou seja, a pesquisa era liberada e podia contar com financiamento federal desde que o processo de derivação dos embriões fosse anterior a 9 de agosto de 2001. Era proibido o uso de investimentos federais para pesquisa com linhagens de células-tronco criadas após aquela data.Os pesquisadores da área afirmam que as linhagens mais novas, criadas com dinheiro privado durante o período de proibição, são mais saudáveis e mais adequadas ao estudo de terapias.

\footnotetext{
${ }^{33}$ GRAIEB, Carlos. STF e a decisão: pesquisas com células-tronco é constitucional. Disponível em < http://arquivoetc.blogspot.com/2008/05/stf-deciso-pesquisa-com-clulas-tronco.html > Acesso em 23 mar.2009.

${ }^{34}$ BRAGA, Kátia Soares; DINIZ, Débora. Anexo ao Memorial formulado pelo amicus curiae: ANIS: Instituto de Bioética, Direitos Humanos e Gênero. Disponível em: < http://www.ccr.org.br/uploads/noticias/adi_3510_memorial_anis_2.pdf $>$. Acesso em 23 mar. 2009.p 11 .

${ }^{35}$ CANÇÃO NOVA NOTÍCIAS. Obama libera pesquisas com células-tronco embrionárias. Disponível em < http://noticias.cancaonova.com/noticia.php?id=272469>. Acesso em 24 mar.2009.
} 
Mesmo com as restrições de financiamento público do governo de George W. Blush, alguns estados como a Califórnia e Illinois editaram leis que autorizavam o financiamento estadual para as pesquisas.

Recentemente, no governo de Barack Obama, em 9 de março de 2009, foi aprovada a liberação de financiamento federal para pesquisas com células-tronco humanas. $\mathrm{O}$ acordo assinado por Obama coloca fim ao limite de financiamento assinado oito anos atrás por George Bush que proibia destinar fundos à criação de células-tronco embrionárias, mas encorajava a pesquisa com células-tronco adultas, consideradas mais promissoras por cientistas e, além disso, evitava consequências éticas.

A justificativa dada por George W. Bush era baseada na defesa da vida humana. Já Barack Obama, criticando o governo do presidente Bush, disse que "Em vez de impulsionar descobertas, nosso governo forçou o que me parece ser uma falsa escolha entre ciência sólida e valores morais. Neste caso, creio que os dois não são inconsistentes. Como pessoa de fé, creio que somos chamados a cuidar uns dos outros e trabalhar para aliviar o sofrimento humano. Acredito que nos foram dadas a capacidade e a vontade de avançar nessas pesquisas, e a humanidade e a consciência de fazer isso de forma responsável." 36

\subsection{Espanha ${ }^{37}$}

Em 2007 o Congresso Espanhol aprovou, em caráter definitivo, a Lei de Pesquisa Biomédica, que permite a clonagem com fins terapêuticos e, em hipótese alguma, para casos reprodutivos.

\footnotetext{
${ }^{36}$ GLOBO.COM.Obama libera pesquisas com células-tronco com dinheiro federal nos EUA. Disponível em<http://g1.globo.com/Noticias/Ciencia/0,,MUL1034916-5603,00OBAMA+LIBERA+PESQUISA+COM+CELULASTRONCO+COM+DINHEIRO+FEDERAL+ NOS+EUA.html>. Acesso em 24 mar.2009

${ }^{37} \mathrm{O}$ VERBO.Congresso Espanhol aprova a clonagem terapêtica. Disponível em< http://www.overbo.com.br/portal/2007/06/15/3692/>.Acesso em 25 mar.2009.
} 
A lei que proíbe expressamente a clonagem de seres humanos (clonagem reprodutiva) e a criação de embriões destinados à pesquisa, permite a utilização de qualquer técnica de obtenção de células-tronco embrionárias humanas com fins terapêuticos ou de pesquisa, sempre que isto não leve à criação de um pré-embrião ou de um embrião exclusivamente com este fim.

Esta lei permitirá que os cientistas espanhóis avancem na pesquisa da clonagem terapêutica, que consiste em transferir um núcleo da célula adulta de um paciente para um ovócito ao qual foi extraído previamente seu núcleo, com a finalidade de reprogramar seu crescimento celular e tentar reorientá-lo para a criação de órgãos e tecidos que depois podem ser transplantados no paciente para tratar alguma patologia.

A lei também estabelece normas para a regulamentação. Assim como no Brasil e em grande parte dos países que possuem legislação a respeito do uso de células-tronco embrionárias para pesquisas científicas, é necessário o consentimento dos genitores. $\mathrm{O}$ órgão que analisa os protocolos de pesquisa é o Comitê de Bioética da Espanha.

A imprensa espanhola afirmou que, com a aprovação desta lei, a Espanha se tornou o nono país do mundo e o quarto da Europa a legalizar a clonagem terapêutica depois de Grã-Bretanha, Bélgica, Suécia, Japão, Austrália, Israel, Coréia do Sul e Cingapura.

\subsection{Reino Unido}

O Reino Unido foi o primeiro país no mundo a ter lei específica sobre pesquisas com células-tronco embrionárias. É a legislação considerada mais liberal do mundo.

Em 2001, o parlamento britânico aprovou, por 366 a 174 votos, o uso de células-tronco extraídas de embrião humano para pesquisas. Isso ocorreu 
com a alteração de uma lei de 1990, que permitia o uso de embriões no prazo de 14 dias da fecundação, porém, tão somente, para pesquisas envolvendo infertilidade e tratamento de doenças congênitas. A clonagem humana permanece ilegal no país, de acordo com as alterações da Lei de Embriologia e Fertilização Humana, de 1990.

O primeiro-ministro na época, Tony Blair, concordou com a decisão. Ele acredita que assim a Grã-Bretanha "manterá sua liderança na área da biotecnologia". ${ }^{38}$

O Reino Unido também é o único país que permite o desenvolvimento de embriões humanos especificamente para fins de pesquisas. ${ }^{39}$

Existe um órgão regulador, assim como na maioria dos países que permitem a pesquisa com células-tronco obtidas de embriões humanos. No Reino Unido esse órgão é a Autoridade de Fertilização Humana e Embriológica (HFEA).

\subsection{França}

$\mathrm{Na}$ França não há uma legislação específica sobre o tema, o assunto está tratado no Decreto 2006-121 de 6 de fevereiro de 2006 ,que modificou o Código de Saúde Pública. De acordo com o decreto só podem ser utilizados os embriões produzidos para fins de fertilização e que não poderão ser implantados. Porém as pesquisas só são permitidas pela agência de biomedicina por um período máximo de 5 anos. Além disso, só é permitido a pesquisa em casos "em que os progressos terapêuticos

\footnotetext{
38 DEFESA DA VIDA. Notícias $d a$ defesa da vida.. Disponível em http://www.defesadavida.com.br/noticias_040101.htm. Acesso em 26mar.2009.

${ }^{39}$ GRAIEB, Carlos. STF e a decisão: pesquisas com células-tronco é constitucional. Disponível em $<$ http://arquivoetc.blogspot.com/2008/05/stf-deciso-pesquisa-com-clulas-tronco.html > Acesso em 26 mar.2009.
} 
almejados não puderem ser alcançados por um método alternativo de eficácia comparável mo meio científico." ${ }^{40}$

${ }^{40}$ JUSBRASIL.Voto de Gilmar Mendes. Disponível em $<$ http://www.jusbrasil.com.br/noticias/17940/leia-voto-de-gilmar-mendes-sobre-pesquisas-comcelulas-tronco $>$. Acesso em 26 marc. 2009. 


\section{Células-Tronco e a Lei $\mathrm{n}^{0} 11.105 / 2005$}

\subsection{Histórico legislativo da Lei $n^{\circ} 11.105 / 2005^{41}$}

O Projeto de Lei que fez resultar na Lei $n^{0} 11.105 / 2005$ foi de iniciativa do Presidente da República. Em 3.10.2003 foi encaminhado à Câmara dos Deputados como Mensagem n n579. As pesquisas com célulastronco estavam contempladas no texto original e recebeu parecer favorável do Relator da Comissão Especial, Deputado Aldo Rebelo. Entretanto no texto que veio a ser aprovado no Plenário e enviado ao Senado, a pesquisa com células-tronco não foi contemplada. Posteriormente o texto foi recomposto na Câmara Alta após amplo e exaustivo debate, havendo tramitado por várias comissões e tendo sido submetido a inúmeras audiências públicas realizadas entre dezembro de 2003 a junho de 2004.

Em 20 de setembro de 2004 foram apresentados os pareceres dos Senadores Osmar Dias e Ney Suassuna e em 6 de outubro de 2004 a matéria foi discutida em Plenário, com a manifestação oral de diversos Senadores. O Projeto já constando a previsão das pesquisas com célulastronco, foi aprovado por 53 votos a 2. Em seguida foi reenviado à Câmara dos Deputados, submetido à nova deliberação e finalmente aprovado em 4 de março de 2004. Em 14 de outubro de 2004 o Projeto de Lei foi sancionado pelo Presidente da República, convertendo-se na Lei $11.105 / 2005$.

\footnotetext{
41 BARroso, Luiz Roberto.Pedido de ingresso como amicus curiae. Disponível em $<$ http://www.lrbarroso.com.br/pt/noticias/minuta_amicus_curiae_lrb_30set05.pdf $>$ Acesso em 19 mar.2009.
} 


\subsection{Comentários sobre a Lei $n^{\circ} 11.105 / 2005$}

O uso de embriões humanos para pesquisas foi permitido e definido no Brasil através da Lei n ${ }^{\circ} 11.105$, de 24 de março de 2005, a chamada Lei de Biossegurança( ANEXO II).

Esta lei regulamenta os incisos II, IV e V do $\S 1^{1^{\circ}}$ do art. 225 da Constituição Federal, estabelece normas de segurança e mecanismos de fiscalização de atividades que envolvam organismos geneticamente modificados - OGM e seus derivados, cria o Conselho Nacional de Biossegurança - CNBS, reestrutura a Comissão Técnica Nacional de Biossegurança - CTNBio, dispõe sobre a Política Nacional de Biossegurança - PNB, revoga a Lei no 8.974, de 5 de janeiro de 1995, e a Medida Provisória $n^{\circ} 2.191-9$, de 23 de agosto de 2001, e os arts. $5^{\circ}, 6^{\circ}, 7^{\circ}$, $8^{\underline{0}}, 9^{\underline{0}}, 10$ e 16 da Lei no 10.814 , de 15 de dezembro de 2003.

De acordo com Vinicius Roberto Prioli de Souza e Luciana Laura Tereza Oliveira Catana:

"a Lei de Biossegurança abrange temas distintos: a pesquisa e a fiscalização dos organismos geneticamente modificados (OGM); a utilização de células-tronco embrionárias para fins de pesquisa e terapia; o papel, a estrutura, as competências e o poder da CTNBio; e, por fim, a formação do Conselho Nacional de Biossegurança - CNBS e sua organização. Deste modo, ocorreu uma "confusão" legislativa, tendo em vista que esta Lei trata de temas totalmente distintos, como transgênicos e células-tronco., ${ }^{42}$

Em seu artigo $3^{\circ}$, a Lei $\mathrm{n}^{\mathrm{o}} 11.105$ apresenta diversas definições importantes, entre as quais a de célula-tronco embrionária. A definição legal de células-tronco embrionárias acompanhou a definição dada pela comunidade científica:

Art. $3^{\circ}$ Para os efeitos desta Lei, considera-se:

\footnotetext{
${ }^{42}$ CATANA, Tereza Oliveira; SOUZA, Vinícius Roberto Prioli de. Células-tronco e o Direito brasileiro. Boletim Jurídico, Uberaba/MG, a. 4, no 183. Disponível em:

$<$ http://www.boletimjuridico.com.br/ doutrina/texto.asp?id=1359> Acesso em: 17 mar. 2009.
} 
I - organismo: toda entidade biológica capaz de reproduzir ou transferir material genético, inclusive vírus e outras classes que venham a ser conhecidas;

II - ácido desoxirribonucléico - ADN, ácido ribonucléico - ARN: material genético que contém informações determinantes dos caracteres hereditários transmissíveis à descendência;

III - moléculas de ADN/ARN recombinante: as moléculas manipuladas fora das células vivas mediante a modificação de segmentos de ADN/ARN natural ou sintético e que possam multiplicar-se em uma célula viva, ou ainda as moléculas de ADN/ARN resultantes dessa multiplicação; consideram-se também os segmentos de ADN/ARN sintéticos equivalentes aos de ADN/ARN natural;

IV - engenharia genética: atividade de produção e manipulação de moléculas de $\mathrm{ADN} / \mathrm{ARN}$ recombinante;

V - organismo geneticamente modificado - OGM: organismo cujo material genético - ADN/ARN tenha sido modificado por qualquer técnica de engenharia genética;

VI - derivado de OGM: produto obtido de OGM e que não possua capacidade autônoma de replicação ou que não contenha forma viável de OGM;

VII - célula germinal humana: célula-mãe responsável pela formação de gametas presentes nas glândulas sexuais femininas e masculinas e suas descendentes diretas em qualquer grau de ploidia;

VIII - clonagem: processo de reprodução assexuada, produzida artificialmente, baseada em um único patrimônio genético, com ou sem utilização de técnicas de engenharia genética;

IX - clonagem para fins reprodutivos: clonagem com a finalidade de obtenção de um indivíduo;

$\mathrm{X}$ - clonagem terapêutica: clonagem com a finalidade de produção de células-tronco embrionárias para utilização terapêutica;

XI - células-tronco embrionárias: células de embrião que apresentam a capacidade de se transformar em células de qualquer tecido de um organismo. (grifo meu).

$\S 1^{\underline{0}}$ Não se inclui na categoria de OGM o resultante de técnicas que impliquem a introdução direta, num organismo, de material hereditário, desde que não envolvam a utilização de moléculas de ADN/ARN recombinante ou OGM, inclusive fecundação in vitro, conjugação, transdução, transformação, indução poliplóide e qualquer outro processo natural.

$\S 2^{\underline{0}}$ Não se inclui na categoria de derivado de OGM a substância pura, quimicamente definida, obtida por meio de processos biológicos e que não contenha OGM, proteína heteróloga ou ADN recombinante.

$\mathrm{O}$ artigo $5^{\circ}$ da Lei $\mathrm{n}^{\circ} 11.105 / 2005$ é o que permite a utilização de células-tronco embrionárias, para fins de pesquisa e terapia, nos seguintes termos:

Art. $5^{0}$ É permitida, para fins de pesquisa e terapia, a utilização de células-tronco embrionárias obtidas de embriões humanos produzidos por fertilização in vitro e não utilizados no respectivo procedimento, atendidas as seguintes condições:

I - sejam embriões inviáveis; ou 
II - sejam embriões congelados há 3 (três) anos ou mais, na data da publicação desta Lei, ou que, já congelados na data da publicação desta Lei, depois de completarem 3 (três) anos, contados a partir da data de congelamento.

$\S 1^{\circ}$ Em qualquer caso, é necessário o consentimento dos genitores.

$\S 2^{2}$ Instituições de pesquisa e serviços de saúde que realizem pesquisa ou terapia com células-tronco embrionárias humanas deverão submeter seus projetos à apreciação e aprovação dos respectivos comitês de ética em pesquisa.

$\S 3^{0}$ É vedada a comercialização do material biológico a que se refere este artigo e sua prática implica o crime tipificado no art. 15 da Lei $n^{\circ} 9.434$, de 4 de fevereiro de 1997.

Este artigo foi regulamentado pelo decreto 5.591 de 23 de novembro de 2005, que considerou no seu artigo $3^{\circ}$, inciso XIV, que os embriões congelados disponíveis são os congelados até o dia 28 de março de 2005, depois de contemplados três anos contados a partir da data do seu congelamento.Já embriões inviáveis também estão definidos neste mesmo artigo no inciso XIII e são os considerados aqueles com alterações genéticas comprovadas por diagnóstico pré implantacional, conforme normas específicas estabelecidas pelo Ministério da Saúde, que tiveram seu desenvolvimento interrompido por ausência espontânea de clivagem após período superior a vinte e quatro horas a partir da fertilização in vitro, ou com alterações morfológicas que comprometam o pleno desenvolvimento do embrião.

Embriões remanescentes são aqueles excedentes de um projeto reprodutivo de um casal que, com restrições de fertilidade, tenha buscado a medicina para ter filhos biologicamente vinculados. Regra geral, após a concretização do projeto reprodutivo, os casais preferem doar os embriões congelados para a pesquisa científica a descartá-los. ${ }^{43}$

A lei, no que diz respeito a clonagem terapêutica, é proibitiva:

Art. $6^{\circ}$ Fica proibido:

\footnotetext{
${ }^{43}$ BRAGA, Kátia Soares; DINIZ, Débora. Anexo ao Memorial formulado pelo amicus curiae: ANIS: Instituto de Bioética, Direitos Humanos e Gênero. Disponível em: < http://www.ccr.org.br/uploads/noticias/adi_3510_memorial_anis_2.pdf $>$. Acesso em 23 mar. 2009.p 8 .
} 


\title{
(...)
}

IV - clonagem humana;

Segundo a opinião de Lygia da Veiga Pereira,

\begin{abstract}
“ apesar da limitação no que diz respeito à clonagem terapêutica, proibida junto com a clonagem reprodutiva no artigo $6^{\circ}$, esta lei foi recebida como uma vitória pela maioria da comunidade científica brasileira e permite que agora o Brasil passe de mero observador para um participante competitivo do desenvolvimento de uma área promissora na medicina. Afinal, o país já demonstrou excelência nas pesquisas com CT de medula e de cordão umbilical, e agora poderá fazer o mesmo com as CT embrionárias. $" 44$
\end{abstract}

A Lei n. 11.105 possui uma peculiaridade já que fala em embriões inviáveis para o uso em pesquisas. É o único país dentre os 25 que foram objeto da pesquisa retro mencionada (vide capítulo 2) que faz a diferenciação legal entre embriões congelados viáveis e inviáveis para a pesquisa científica. Os outros países têm a tendência de demarcar a distinção entre embriões congelados remanescentes de projetos reprodutivos e embriões produzidos para fins exclusivos de pesquisa científica. Há um maior consenso na legislação internacional em reconhecer como legítima a pesquisa com embriões congelados, não autorizando sua produção exclusivamente para pesquisas.

\footnotetext{
${ }^{44}$ ZAGO, Marco Antônio; COVAS, Tadeu Dimas. Células-Tronco: A Nova Fronteira da Medicina. São Paulo: Atheneu, 2006.p.32
} 


\section{A Vida}

A garantia Constitucional da inviolabilidade da vida, de que trata o caput do artigo $5^{\circ}$ da Constituição Federal, depende da definição do momento em que ocorre o início da vida. Porém a questão de quando tem início a vida humana tem sido feita ao longo de toda a história da civilização e as respostas têm se mostrado extremamente mutáveis, alterando-se de acordo com o tempo e as características da sociedade, passando por valores individuais de pessoas, sejam elas cientistas ou leigas.

\subsection{Concepção Jurídica}

Não existe na Constituição Federal, do ponto de vista técnico, um conceito claro de quando começa a vida. $\mathrm{O}$ direito não tem resposta para essa questão que é fundamentalmente moral. O ministro Carlos Ayres Britto, na Audiência Pública do dia 20 de abril de 2007, afirmou que a partir do subsídio oferecido pela comunidade científica, os ministros do STF poderão formular "um conceito operacional de vida, do início da vida, da própria dignidade da pessoa humana para tornar a Constituição eficaz" ${ }^{45}$

De acordo com Erickson Gavazza Marques, especialista em biodireito, não cabe ao STF decidir onde começa a vida. A Constituição garante o direito à vida, mas não diz o que é vida e nem quando ela começa. Segundo ele:

\footnotetext{
${ }^{45}$ NOTÍCIAS STF. Disponível em< http://www.stf.jus.br/portal/cms/verNoticiaDetalhe.asp?idConteudo=69682\&caixaBusca=N $>$ Acesso em 24 abr.2009.
} 
"Em nenhum momento, a Constituição diz o que é vida, e nem poderia. As leis tratam das conseqüencias da vida. A partir do momento em que o ser humano nasce, está sujeito a direitos e obrigações "46

O direito civil brasileiro, desde o projeto de Teixeira de Freitas, passando pelo Projeto de Clóvis Bevilácqua, pelo Código Civil de 1916 e o Código Civil de 2002, estabelece que a personalidade civil do ser humano começa do nascimento com vida, salvaguardando a lei, desde a concepção, os direitos do nascituro. ${ }^{47}$

Dentro deste quadro normativo, podemos depreender duas assertivas que caminham em direções opostas: a corrente natalista: compreende que a personalidade civil da pessoa é iniciada no momento do seu nascimento, sendo neste momento reconhecida a sua capacidade de sujeito de direitos; a corrente concepcionista: entende que a lei retroage os direitos da pessoa ao momento de sua concepção, sendo reconhecida então a personalidade civil do nascituro.

A maioria das legislações, assim como a brasileira, é fluida quanto à determinação do significado jurídico da vida embrionária e dos direitos daí decorrentes. O Novo Código Civil, quando trata de filiação, nada fala sobre a vida embrionária.

Os doutrinadores não chegaram a um consenso sobre a definição jurídica do início da vida. Alguns preferem, até mesmo, enfrentar a questão do aborto, mas não enfrentar a questão do início da vida.

\footnotetext{
${ }^{46}$ PINHEIRO, Aline; Não cabe a Constituição definir o que é vida, diz especialista. Disponível em $<$ http://www.conjur.com.br/2005-nov-06/nao_cabe_lei_definir_vida_especialista $>$. Acesso em 13 abr. 2009.

${ }^{47}$ BARRETO, Vicente de Paulo.A idéia de Pessoa Humana e os Limites da Bioética. In: BARBOZA, Heloísa Helena; MEIRELLES, Jussara Maria Leal; BARRETO, Vicente de Paulo (org). Novos temas de Biodireito e Bioética.Rio de Janeiro/ São Paulo: Renovar,2003.p.223
} 
Não parece muito pertinente a discussão se a Constituição brasileira definiu ou não quando seria o exato momento do início da vida humana. Certo é que pelo texto literal do dispositivo não há nenhuma menção expressa a essa definição. A Constituição apenas definiu os direitos concernentes a pessoa.

\subsection{Concepção Científica}

Desde a antiguidade, a indagação sobre o início da vida preocupou filósofos, cientistas e juristas. Para Aristóteles, a pessoa humana tornava-se apta a ser considerada integrante da humanidade, na $28^{\mathrm{a}}$ semana depois da fecundação.

A biologia contemporânea, por sua vez, estabelece a viabilidade humana na $24^{\mathrm{a}}$ semana. Porém não há uma determinação cientificamente mais precisa. Alguns dizem que se o feto apresentar características de vida poderia ser considerado uma pessoa em potencial e isso ocorreria por volta da segunda semana de gestação. ${ }^{48}$

Percebe-se que a própria comunidade científica diverge sobre o início da vida humana, não encontrando uma resposta aceita uniformemente por todos.

As respostas encontradas no âmbito científico tratam de conceber a pessoa humana como o resultado de um desenvolvimento do qual o embrião representa um dos primeiros estágios. Assim, como exemplo, o comitê britânico recomendou que a utilização de embriões humanos para fins de pesquisa fosse permitida no prazo de 14 dias da fecundação. $\mathrm{O}$ argumento utilizado para o estabelecimento deste prazo foi o de que um grupo de células não tem individualidade própria e não sofre, por não terem os

\footnotetext{
${ }^{48}$ Ibid. p. 227.
} 
primeiros indícios do sistema nervoso. Esse argumento expressa uma filosofia utilitarista, pois estabelece limites em função do sofrimento a ser impingido ao feto, deixando de lado o debate da natureza da pessoa humana.

Por não se encontrar uma resposta pacífica no meio científico sobre o que é a pessoa humana, torna-se necessário que se busque uma justificativa de caráter racional que sirva de fundamento para a construção desse novo sujeito de direito da sociedade tecnocientífica contemporânea.

\subsection{Concepção Religiosa}

A corrente filosófica chamada vitalista encontra a sua expressão mais sistemática na doutrina católica, como se encontra nos ensinamentos de Tomás de Aquino e na posição de diversos documentos papais. ${ }^{49}$

O argumento vitalista está pautado na idéia de que o ser humano seria constituído de corpo e alma, e a incorporação desta ao corpo humano, ou a sua saída, é o que determinaria o momento do nascimento e da morte da pessoa humana. Porém essa teoria gera uma dúvida, que é a de saber precisar em que momento a alma é recebida pelo corpo de uma pessoa e quando efetivamente sai do corpo do moribundo.

Este argumento pode ser compreendido quando considerarmos um princípio formulado primeiramente na Grécia por Aristóteles, que é o chamado princípio do Hilemorfismo. Segundo o hilemorfismo toda a natureza é composta de matéria e de forma. Mais especificamente, ele sustenta que cada corpo natural é composto por dois princípios substanciais: a matéria-prima e a forma substancial. O próprio Tomás de Aquino afirma que não existe corpo humano sem alma humana.

\footnotetext{
${ }^{49}$ Ibid.p.233/235.
} 
A tradição católica considera que o critério a ser observado é a existência do embrião, quando se supõe ter havido a animação imediata com a recepção da alma pelo corpo. Para o tomismo, o ser humano enquanto entidade biológica é sujeito de direitos, as palavras "homem" e "pessoa" são consideradas sinônimas, não seria necessário ter uma vida pessoal para que se possa ser uma pessoa.

Pessoa, para o tomismo, é um ser dotado de racionalidade e personalidade, que se expresse pelo homem ontológico, comprovado pela presença de uma propriedade biológica, genoma ou animação.

\subsection{Princípio da Dignidade da Pessoa Humana}

A importância do princípio da dignidade da pessoa humana transcende os limites do positivismo. ${ }^{50}$

Segundo Carmen Lúcia Antunes Rocha, em palestra proferida na XVII Conferência Nacional da Ordem dos Advogados do Brasil em 1999: "Dignidade é o pressuposto da idéia de justiça humana, porque ela é que dita a condição superior do Homem como ser de razão e sentimento. Por isso é que a dignidade humana independe de merecimento pessoal ou social. Não se há de se mister ter de fazer por merecê-la, pois ela é inerente à vida e, nessa contingência é um direito pré-estatal".

Este princípio é o verdadeiro princípio fundamental da ordem jurídica. Obriga irrestrita e incontornavelmente o Estado, seus dirigentes e

\footnotetext{
${ }^{50}$ PIOVESAN, Flávio. Temas de Direitos Humanos. São Paulo: MAX Limonad, 2003.p.389
} 
atores da cena política governamental, pelo que tudo que o contrarie é nulo. $^{51}$

A compreensão do conteúdo e significado da Dignidade da Pessoa Humana para a ordem jurídica, trata-se de tema polêmico e que tem ensejado farta discussão em nível doutrinário e até mesmo Jurisprudencial. $^{52}$

Uma conceituação clara do que seja efetivamente esta dignidade, até para efeitos de definição do seu âmbito de proteção como norma jurídica fundamental, é no mínimo difícil de ser obtida. Essa dificuldade se dá da circunstância de que se cuida de conceitos de contornos vagos e imprecisos, por conta da sua "ambigüidade e porosidade", assim como por sua natureza polissêmica. Uma das principais dificuldades é que este princípio não se cuida de aspectos mais ou menos específicos da existência humana, como é a integridade física, a intimidade e a propriedade, por exemplo, mas, sim, de uma qualidade tida como inerente a todo e qualquer ser humano. Por isso é definida comumente como integrando o valor próprio que identifica o ser humano como tal. Essa definição não contribui para a compreensão satisfatória do que efetivamente é o âmbito de proteção da dignidade, na sua condição jurídico-normativa. ${ }^{53}$

É mais fácil dizer o que a dignidade não é do que expressar o que ela é, já que podemos vislumbrar e estabelecer uma pauta exaustiva de suas violações.

Nesse contexto a dignidade da pessoa humana não pode ser conceituada de maneira a ser única, se for feita uma definição nesses termos

\footnotetext{
${ }^{51}$ Ibid p. 390

52 SCARLET, Ingo Wolfgang. Dignidade da Pessoa Humana e Direitos Fundamentais. Porto Alegre:Livraria do Advogado, 2004.p.27

${ }^{53}$ Ibid pp. 39/40.
} 
não se harmonizaria com o pluralismo e a multiplicidade de valores que se manifestam nas sociedades democráticas contemporâneas. Sendo assim, o conceito de dignidade da pessoa humana está em permanente processo de construção e desenvolvimento. ${ }^{54}$

A dignidade. como qualidade intrínseca do ser humano, é irrenunciável e inalienável. Não pode ser criada, concedida ou retirada, embora possa ser violada. Independe das circunstâncias concretas, já que inerente a toda e qualquer pessoa humana. ${ }^{55}$

\begin{abstract}
"Assim sendo, temos por dignidade da pessoa humana a qualidade intrínseca e distintiva reconhecida em cada ser humano que o faz merecedor do mesmo respeito e consideração por parte do Estado e da comunidade, implicando, nesse sentido, um complexo de direitos e deveres fundamentais que asseguram a pessoa tanto contra todo e qualquer ato de cunho degradante e desumano, como venham a lhe garantir as condições existenciais mínimas para uma vida saudável, além de propiciar e promover sua participação ativa e co-responsável nos destinos da própria existência e da vida em comunhão com os demais seres humanos." 56
\end{abstract}

Para dar resposta à questão que surge quanto ao status dos embriões resultantes da técnica de reprodução humana assistida, como, por exemplo, em que medida os valores fundamentais e determinantes dos seres humanos na cultura filosófica e jurídica ocidental podem servir para conceituar o novo sujeito, que aguarda a consagração de seus direitos e deveres no sistema normativo da sociedade tecno-científica, juristas e legisladores se socorreram dos princípios, especificamente o da dignidade da pessoa humana. Porém a idéia da dignidade não é originariamente jurídica, fruto da doutrina ou legislação, mas resultante de uma compreensão específica da

\footnotetext{
${ }^{54}$ Ibid p.41

${ }^{55}$ Ibid p.44

${ }^{56}$ Ibid p.60
} 
natureza da pessoa humana e da sociedade. Usar a dignidade humana sem situar no quadro de uma ética e antropologia filosófica determinada significa lançar o valor que ela representa no vazio dos discursos políticos e jurídicos. $^{57}$

$\mathrm{Na}$ filosofia clássica, nenhuma escola do pensamento considerou como existindo uma relação entre a idéia de dignidade da pessoa humana e a forma democrática de governo. Não havia no pensamento político clássico nenhuma tentativa de justificar a democracia a partir da essência do homem ou da idéia de "humanidade".

Esse quadro muda na contemporaneidade, defrontamo-nos com uma problemática que se expressa em duas questões subjacentes à idéia da dignidade da pessoa humana. A primeira questão se refere à determinação dos critérios que possam distinguir entre todos os seres vivos, quais podem ser classificados como incluídos à categoria "pessoa humana”. Já a segunda questão se situa onde se irá atribuir a essa "pessoa humana" uma série de valores que são determinantes e caracterizadores dos direitos humanos. ${ }^{58}$

${ }^{57}$ BARRETO, Vicente de Paulo.A idéia de Pessoa Humana e os Limites da Bioética. In: BARBOZA, Heloísa Helena; MEIRELLES, Jussara Maria Leal; BARRETO, Vicente de Paulo (org). Novos temas de Biodireito e Bioética. Rio de Janeiro/ São Paulo: Renovar,2003.p.220

${ }^{58}$ Ibid. pp. 221/222. 


\section{Discussão sobre a Legalidade do artigo $5^{\circ}$ e parágrafos da Lei $n^{\circ} 11.105 / 2005$}

\subsection{Adin $n^{\circ} 3510$}

Em 30 de maio de 2005, o então procurador-Geral da República, Claudio Fonteles, ajuizou Ação Direta de Inconstitucionalidade, que recebeu o número de 3510 (ANEXO III), no Supremo Tribunal Federal contra parte da Lei de Biossegurança (Lei $\left.\mathrm{n}^{\circ} 11.105 / 2005\right)$. Os dispositivos questionados são o artigo $5^{\circ}$ da referida lei e seus parágrafos. Esses dispositivos permitem a utilização de células-tronco de embriões humanos para fins de pesquisa e terapia.

De acordo com Cláudio Fonteles, o artigo $5^{\circ}$ e parágrafos da lei impugnada dispõem que poderão ser utilizados embriões humanos "inviáveis" ou congelados há três anos ou mais, sendo necessário o consentimento dos genitores. Para o procurador-geral, os dispositivos ferem o artigo 5" "caput" da Constituição Federal, no que tange a proteção constitucional do direito à vida e o artigo $1^{\circ}$, inciso III, que estabelece a dignidade da pessoa humana como fundamento da República Federativa do Brasil.

A tese cental da petição afirma que a vida humana acontece na, e a partir da, fecundação e ressalta que "o embrião humano é vida humana". Na $\mathrm{ADI}$, ele cita trechos de vários especialistas em bioética e sexualidade humana para demonstrar sua tese, como o cientista Jérôme Lejeune, professor da universidade de René Descartes, em Paris, descobridor da Síndrome de Dawn, que diz: 
"Não quero repetir o óbvio, mas, na verdade, a vida começa na fecundação. Quando os 23 cromossomos masculinos se encontram com os 23 cromossomos da mulher, todos os dados genéticos que definem o novo ser humano estão presentes. A fecundação é o marco do início da vida. Daí para frente, qualquer método artificial para destruí-la é um assassinato".

$\mathrm{Na}$ petição ele também tenta demonstrar que os avanços mais promissores da pesquisa científica ocorrem com as células-tronco adultas e não com as células-tronco embrionárias e também que no meio científico houve a superação do preconceito contra as células-tronco adultas.

Ele usa o exemplo da Alemanha que, no plano legislativo, existe lei específica de proteção aos embriões, dizendo que em geral é proibido o uso de embriões humanos para fins outros que o de provocar a gravidez, por isso a pesquisa científica com embriões humanos alemães é proibida. Com a promulgação da lei sobre importação e uso de células-tronco humanas em 2002, passou-se a admitir o uso de células-tronco embrionárias importadas, desde que seguidos alguns requisitos.

Fonteles, na petição datada de 16 de maio de 2005, salienta as seguintes premissas:

"- que a vida humana acontece na, e a partir da, fecundação: o zigoto, gerado pelo encontro dos 23 cromossomos masculinos com os 23 cromossomos femininos;

- a partir da fecundação, porque a vida humana é contínuo desenvolverse;

- contínuo desenvolver-se porque o zigoto, constituído por uma única célula, imediatamente produz proteínas e enzimas humanas, é totipotente, vale dizer, capacita-se, ele próprio, ser humano embrionário, a formar todos os tecidos, que se diferenciam e se auto-renovam, constituindo-se em ser humano único e irrepetível.

- a partir da fecundação, a mãe acolhe o zigoto, desde então propiciando o ambiente a seu desenvolvimento, ambientação que tem sua etapa final na chegada ao útero. Todavia, não é o útero que engravida, mas a mulher, por inteiro, no momento da fecundação.

- a pesquisa com células-tronco adultas é, objetiva e certamente, mais promissora do que a pesquisa com células-tronco embrionárias, até porque com as primeiras resultados auspiciosos acontecem, do que não se tem registro com as segundas." 
Depois, ressalta que os dispositivos objeto dessa ação, estabelecidas as premissas acima, inobservam a inviolabilidade do direito à vida, já que conclui que embrião é vida humana, e "faz ruir fundamento maior do Estado democrático de direito, que radica na preservação da dignidade da pessoa humana."

Ao final, pede a declaração de inconstitucionalidade do artigo $5^{\circ} \mathrm{e}$ parágrafos da Lei de Biossegurança e solicita a realização de audiência pública para discutir o assunto. Fonteles também apresenta uma lista de especialistas para que fossem intimados para falar sobre o tema.

\subsection{Audiência Pública}

Carlos Ayres Britto, ministro do Supremo Tribunal Federal e relator da Ação Direta de Inconstitucionalidade (ADI) 3510, em 19 de Dezembro de 2006, determinou a realização de audiência pública, para discutir com a sociedade civil o uso de células-tronco embrionárias para pesquisa. Dado a relevância da matéria em vista dos "múltiplos entendimentos a respeito do direito à vida", o ministro entendeu que a audiência se fazia necessária para subsidiar os ministros do STF, além de possibilitar maior participação da sociedade civil na análise da presente ADI. Fato este que dá maior legitimidade para a decisão que foi tomada pelo Plenário da Corte.

A data do dia 20 de abril de 2007 foi a escolhida para ser realizada a audiência pública, que foi a primeira audiência pública do STF. Foram convidados 17 especialistas, além dos arrolados por Fonteles, para esclarecer aspectos sobre a matéria questionada na ADI para os Ministros do STF, para o ex Procurador-Geral da República e para os amicus curiae. ${ }^{59}$

\footnotetext{
59
NOTÍCIAS $\quad$ STF.Disponível em $<$ http://www.stf.jus.br/portal/cms/verNoticiaDetalhe.asp?idConteudo=69419\&caixaBusca=N >. Acesso em 22 abri.2009.
} 
No programa "Forum" realizado pela TV Justiça, no dia 16 de abril de 2007, o relator Ayres Britto afirmou que: “A Lei 9.868/99 [Lei das ADIs] possibilita esse tipo de convocação diante de um tema tão complexo, tecnicamente, quanto relevante, social e politicamente". Para ele a audiência pública é um mecanismo da chamada democracia direta. "Significa tirar o povo da platéia e colocá-lo no palco das decisões que lhe digam respeito. O povo deixando de ser passivo expectador para ser um ativo condutor do seu próprio destino", afirmou. ${ }^{60}$

A lista dos especialistas que foram chamados pelo STF para participar da audiência pública constou dos seguintes nomes: Mayana Zatz, geneticista, professora-titular da Universidade de São Paulo e presidente da Associação Brasileira de Distrofia Muscular; Lygia da Veiga Pereira, biofísica, professora associada da Universidade de São Paulo, com experiência em genética humana; Rosália Mendes Otero, médica pesquisadora, professora-titular da Universidade Federal do Rio de Janeiro ; Stevens Rehen, neurocientista, presidente da Sociedade Brasileira de Neurociências e Comportamento e professor da UFRJ; Antonio Carlos Campos de Carvalho, médico, doutor em Ciências Biológicas pela UFRJ. Coordenador de pesquisa do Instituto Nacional de Cardiologia Laranjeiras e professor visitante do Albert Einstein College of Medicine, EUA; Luiz Eugenio Araújo de Moraes Mello, médico, pró-reitor de Graduação da Unifesp, vice-presidente da Federação das Sociedades de Biologia Experimental; Drauzio Varella, médico, dirige, ao longo do Rio Negro, um projeto de bioprospecção de plantas brasileiras para testar no combate a células tumorais malignas e a bactérias resistentes a antibióticos; Oscar Vilhena Vieira, advogado especialista em direitos humanos, professor da Escola de Direito da FGV e da PUC-SP e diretor-executivo da Conectas Direitos Humanos; Milena Botelho Pereira Soares, bióloga, ligada à

\footnotetext{
No NOTÍCIAS STF. Disponível em $<$ http://www.stf.jus.br/portal/cms/verNoticiaDetalhe.asp?idConteudo=69626\&caixaBusca=N.> Acesso em 22 abr. 2009.
} 
Universidade Estadual de Feira de Santana, à Fiocruz/BA e à Fundação Oswaldo Cruz; Ricardo Ribeiro dos Santos, médico, pesquisador da Fundação Oswaldo Cruz e coordenador científico do Hospital São Rafael (BA); Esper Abrão Cavalheiro, pesquisador, ex-presidente do $\mathrm{CNPq}$ e da CTNBio, é professor-titular da Universidade Federal de São Paulo; com estudos sobre epilepsia e neurologia experimental; Marco Antonio Zago, médico, diretor da Fundação Hemocentro de Ribeirão Preto, professor da USP e membro da Academia Brasileira de Ciências; Moisés Goldbaum, médico, professor do departamento de Medicina Preventiva da USP; Patrícia Helena Lucas Pranke, farmacêutica, professora da Universidade Federal do Rio Grande do Sul e da PUC-RS, além de presidente do Instituto de Pesquisa com Célula-Tronco; Radovan Borojevic, biólogo, professor titular da Universidade Federal do Rio de Janeiro; Tarcisio Eloy Pessoa de Barros Filho, médico, chefe do Departamento de Ortopedia e Traumatologia da USP; Débora Diniz, antropóloga, diretora-executiva da ONG Instituto de Bioética, Direitos Humanos e Gênero (Anis) e professora da Universidade de Brasília (UnB); Júlio César Voltarelli, professor titular do Departamento de Clínica Médica da FMRP-USP, coordenador da Divisão de Imunologia Clínica, do Laboratório de Imunogenética (HLA) e da Unidade de Transplante de Medula Óssea do HCFMREP-USP.

Já os convidados pela PGR foram: Alice Teixeira Ferreira, professora associada da Unifesp; Cláudia Batista, professora da UFRJ; Elizabeth Kipman Cerqueira, médica ginecologista, coordenadora do Centro de Bioética do Hospital São Francisco de Jacareí (SP); Lilian Piñero Eça, pesquisadora em biologia molecular, integrante do Instituto de Pesquisa com Células-Tronco (IPCTRON); Herbert Praxedes, professor da Faculdade de Medicina da UFF (RJ); Antonio José Eça, diretor de Recursos Humanos do CAS (Células Tronco Centro de Atualização); Lenise Aparecida Martins Garcia, professora-adjunta do Departamento de Biologia Celular da Universidade de Brasília; Marcelo Paulo Vaccari Mazzetti, vice- 
presidente do Instituto de Pesquisa de Células-Tronco; Dalton Luiz de Paula Ramos, livre-docente pela Universidade de São Paulo, Professor de Bioética da USP e membro do Núcleo Interdisciplinar de Biotética da UNIFESP; Dernival da Silva Brandão, especialista em Ginecologia e membro Emérito da Academia Fluminense de Medicina; Rogério Pazetti, graduado em Biologia pela Universidade MACKENZIE e Doutorado em Ciências pela Faculdade de Medicina da USP.

Ainda foram convidados pela Presidência da República Lucia Braga, presidente e diretora-executiva da Rede Sarah; Móisés Goldbaum, professor do Departamento de Medicina Preventiva da Faculdade de Medicina da USP; Patrícia Helena Lucas Pranke, diretora presidente do Instituto de Pesquisa com Célula Tronco e Diretora do Banco de Sangue Cordão Umbilical do Ministério da Saúde e Ricardo Ribeiro dos Santos, foi professor titular da FMRP/USP. Atualmente é pesquisador titular da Fundação Oswaldo Cruz. E pela Confederação Nacional dos Bispos do Brasil (CNBB) foi convidado Rodolfo Acatauassú Nunes, Mestre e Doutor em cirurgia geral pela Universidade Federal do Rio de Janeiro, Livre docente em cirurgia geral torácica pela Universidade Federal do Estado do Rio de Janeiro. ${ }^{61}$

A ministra Ellen Gracie fez a abertura da audiência pública realizada no dia 20 de abril de 2007. Elogiou o ministro Carlos Ayres Britto, de quem partiu a iniciativa para a realização da audiência. Agradeceu a comunidade científica que aceitou trazer os conhecimentos acumulados ao longo do tempo e ressaltou que o ato de julgar é um ato de humildade e por isso o STF decidiu ouvir os especialistas. "O STF se abre para a comunidade científica para se preparar para o julgamento", disse. O conteúdo da audiência pública será todo registrado e entregue aos ministros do STF para

\footnotetext{
$\begin{array}{llll}61 & \text { NOTÍCIAS } & \text { STF. } & \text { Disponível }\end{array}$ $<$ http://www.stf.jus.br/portal/cms/verNoticiaDetalhe.asp?idConteudo=69647\&caixaBusca $=\mathrm{N}$ $\geq$ Acessso em 22 abr.2009.
} 
que analisem com profundidade as colocações dos estudiosos antes da análise do mérito da questão pelo Plenário.

Ao dar as boas vindas aos palestrantes, o ministro Ayres Britto afirmou que os ministros "estão em busca de um conceito jurisdicional para o vocábulo vida". Ressaltou que o tema é tão complicado quanto relevante, por isso a importância da audiência pública. ${ }^{62}$

Os palestrantes forão divididos em dois blocos: os que são a favor de dispositivos da Lei de Biossegurança e os que se posicionam contra.

\subsubsection{Bloco a favor dos dispositivos da Lei de Biossegurança}

Por sorteio foram escolhidos para iniciar suas exposições os especialistas defensores da pesquisa com células-tronco embrionárias.

Mayana Zatz, Patrícia Pranke e Lúcia Braga frisaram a importância de que a legislação permita as pesquisas com células-tronco embrionárias, afirmando que são hoje as únicas com potencial para recuperar as doenças neurológicas incuráveis.

Patrícia Pranke explicou que só a partir do quarto dia o embrião (blastocisto) pode ser implanto no útero, o único ambiente em que ele poderá se desenvolver. Segundo ela, os embriões ou são implantados no útero ou são congelados. "O próprio congelamento diminui a possibilidade de o embrião se desenvolver depois", afirmou. Explicou também que os embriões são classificados em categorias com até quatro graus de qualidade. "Os embriões de má qualidade, chamados embriões inviáveis, chegam a nem ser congelados por algumas clínicas. Por que não doá-los para pequisa?", questionou ela.

\footnotetext{
62 NOTÍCIAS STF. Disponível em $<$ http://www.stf.jus.br/portal/cms/verNoticiaDetalhe.asp?idConteudo=69681\&caixaBusca=N $>$. Acesso em 22 abr.2009.
} 
“A pergunta a ser feita é qual destino será dado aos embriões que não chegam a ser implantados no útero e não quando a vida começa, já que poderemos ficar dias aqui a discutir isso", advertiu. ${ }^{63}$

O médico Ricardo Ribeiro dos Santos, também defensor do uso de células-tronco embrionárias para pesquisas, salientou a necessidade de se permitir pesquisas com esse tipo de células pela capacidade dessas células se transformarem em centenas de tipos de células diferentes do corpo humano.

A professora de genética da Universidade de São Paulo (USP) Mayana Zatz afirmou que a possibilidade de serem desenvolvidas pesquisas com células-tronco de embriões definirá, no futuro, a existência ou não de tratamento para inúmeras doenças degenerativas que atingem a população. "São doenças muito graves, muitas letais, e a população tem nessas pesquisas a única esperança de um futuro tratamento."

Mayana esclareceu que uma célula-tronco embrionária só poderá se tornar um feto por meio da intervenção humana, já que ela tem de ser inserida no útero para tanto. Ainda questionou o que seria eticamente mais correto: "Preservar um embrião congelado, mesmo sabendo que a probabilidade de ele gerar um ser humano é praticamente zero, ou doá-lo para pesquisas que poderão resultar em futuros tratamentos?".

“Toda célula é vida, um coração a ser transplantado é vivo, mas não é um ser humano. Estamos defendendo que, da mesma maneira que um

\footnotetext{
$63 \quad$ NOTÍCIAS $\quad$ STF. Disponível em $<$ http://www.stf.jus.br/portal/cms/verNoticiaDetalhe.asp?idConteudo=69669\&caixaBusca=N >. Acesso em 22abr.2009.
} 
indivíduo em morte cerebral doa órgãos, um embrião congelado possa doar suas células", disse. ${ }^{64}$

Mayana Zatz afirmou que uma vez que a morte cerebral determina o fim da vida, da mesma maneira, somente a partir do $14^{\circ}$ dia há o início da formação da célula nervosa. "Então porque não usar esse mesmo parâmetro para dizer que até 14 dias pode usar as células embrionárias para formar tecidos?", questionou a professora

Também ressaltou que as pesquisas que estão sendo feitas com células-tronco da medula óssea, nas quais são tiradas a medula óssea e injetada em outro órgão, não serve para a doença genética. "Na doença genética, você vai ter todas as suas células com o mesmo erro genético por isso o auto-transplante não serve".

Rosália Mendez Otero afirmou que a utilização de células-tronco é de total importância no tratamento de doenças neurológicas, que têm grande incidência na população e altos índices de mortalidade e morbidade. "O acidente vascular cerebral é a primeira causa de morte no Brasil. No mundo, é o segundo motivo de óbito. $\mathrm{E}$ os que sobrevivem ficam com enormes seqüelas", explicou. Ela defendeu que as células-tronco são fontes seguras e que devem estar disponíveis em nosso país. "Se não tivermos nossas células embrionárias, os brasileiros terão que procurar esse tipo fora do país".

Para Júlio Voltarelli, a utilização somente de células tronco adultas é insuficiente para tratar várias doenças auto-imunes em seu estágio inicial. "Só a utilização de células adultas não é suficiente nesses casos. Precisamos ainda utilizar células-tronco embrionárias".

\footnotetext{
$64 \quad$ NOTÍCIAS STF. Disponível em $<$ http://www.stf.jus.br/portal/cms/verNoticiaDetalhe.asp?idConteudo=69692\&caixaBusca=N $>$. Acesso em 22 abr.2009.
} 
Já para o médico Ricardo Ribeiro dos Santos, pesquisador da Fundação Oswaldo Cruz na Bahia, o principal atrativo da célula embrionária é a sua plasticidade, ou seja, sua enorme capacidade de se transformar em outros 220 tipos de células do corpo humano.

"O conhecimento das células embrionárias vai nos dar o conhecimento para melhor entender o câncer, por exemplo. Já realizamos vários transplantes de fígado com células adultas, mas os pacientes não ficarão totalmente curados. Eles ainda precisarão de mais". ${ }^{65}$

Steven Rehen, também defensor das pesquisas com células-tronco embrionárias, em sua palestra, ressaltou que existe ainda um longo caminho até a utilização clínica das células-tronco embrionárias, como foi no caso das adultas. E que é necessário dar mais tempo para as pesquisas. "Mas é importante ter em mente que, com a pesquisa, existe a possibilidade de tratamento. Sem a pesquisa, a única certeza que teremos é que não haverá tratamento", concluiu. ${ }^{66}$

Lygia Pereira, professora associada do Departamento de Genética e Biologia Evolutiva da USP, afirmou durante a audiência que para se transformar a promessa terapêutica das células-tronco embrionárias é necessário investir em pesquisa.

O cientista Antonio Carlos Campos de Carvalho alertou o público da audiência sobre o atual estágio das pesquisas de células-tronco embrionárias e adultas. Segundo ele, o consenso, hoje, é o de que a capacidade de transformação das células-tronco adultas não ocorre em sua totalidade, mas ocorre sim "a fusão" entre células pluripotentes e multipotentes. Alertou

\footnotetext{
65 NOTÍCIAS STF. Disponível em $<$ http://www.stf.jus.br/portal/cms/verNoticiaDetalhe.asp?idConteudo=69677\&caixaBusca=N $>$. Acesso em 22 abr. 2009.
} 
também que esse fenômeno só ocorre em 1\% (um por cento) dos casos. Se os primeiros estudos fossem verdadeiros, "seria possível transformar cérebro em sangue, ou transformar sangue em cérebro".

\subsubsection{Bloco contra os dispositivos da Lei de Biossegurança}

A primeira a defender a posição é a professora-adjunta do Departamento de Biologia Celular da Universidade de Brasília (UnB), Lenise Aparecida Martins. Ela fala sobre o ciclo de vida da espécie humana e sustenta que a vida humana começa na fecundação, tal como está colocado na ADI 3510, proposta pela PGR. ${ }^{68}$

Lenise concorda com o argumento de Fonteles. Segundo ela, todo ser vivo tem fases diferentes durante o seu ciclo de vida. "O indivíduo não precisa começar a manifestar sua sabedoria para ser considerado humano. O embrião humano já é da espécie homo sapiens mesmo que não possa ainda aprender".

A segunda palestrante pelo bloco composto por pessoas que são contra o uso de células-tronco, Cláudia Maria de Castro Batista afirma que o embrião humano possui uma autonomia. Para ela, a vida humana é um processo contínuo, coordenado e progressivo que começa a partir da fecundação do óvulo pelo espermatozóide. ${ }^{69}$

\footnotetext{
$66 \quad$ NOTÍCIAS $\quad$ STF. $\quad$ Disponível $\quad$ em $<$

http://www.stf.jus.br/portal/cms/verNoticiaDetalhe.asp?idConteudo=69706\&caixaBusca=N $>$. Acesso em 24 abr.2009.

${ }^{67}$ NOTÍCIAS STF. Disponível em < http://www.stf.jus.br/portal/cms/verNoticiaDetalhe.asp?idConteudo=69699\&caixaBusca=N $>$. Acesso em 28 abr.2009.

68 NOTÍCIAS STF. Disponível em < http://www.stf.jus.br/portal/cms/verNoticiaDetalhe.asp?idConteudo=69673\&caixaBusca=N >. Acesso em 22 abr.2009.

69 NOTÍCIAS STF. Disponível em http://www.stf.jus.br/portal/cms/verNoticiaDetalhe.asp?idConteudo=69676\&caixaBusca=N $>$. Acesso em 22 abr.2009.
} 
Para ela "uma vez que o óvulo é fecundado, forma-se a primeira célula do homo sapiens e todo um programa de fertilização é disparado. $\mathrm{O}$ direito à vida e à integridade física desde o primeiro o momento da existência é o princípio de igualdade que deve ser respeitado”.

A especialista Lílian Piñero Eça falou sobre o diálogo entre o embrião humano e sua mãe. Defendeu que duas a três horas depois da fecundação, após o encontro do espermatozóide com o óvulo, o embrião já se comunica com a mãe por meio das moléculas. ${ }^{70}$

Alice Teixeira Ferreira coordena estudos pré-clínicos com célulastronco adultas. Ela questionou durante a audiência pública se é realmente indispensável a utilização da célula-tronco embrionária em pesquisas. Ela garante que o bloco do qual faz parte é a favor da pessoa humana. ${ }^{71}$

Já o médico Marcelo Vacari Mazzenoti, explicou o êxito das experiências com células-tronco adultas nas várias especialidades médicas. Marcelo começou sua explanação explicando que a vida humana começa na fecundação. Ele também afirmou não ser necessária a utilização de célulastronco embrionárias para a medicina atual.

"Podemos utilizar células tronco adultas em diversas situações, como doenças de chagas, doenças auto-imunes, acidentes vasculares cerebrais, lesões de medula espinhal e doenças genéticas, dentre outros. Já com relação à utilização de células tronco embrionárias, não há fato objetivo e concreto que confirme a sua utilidade"

\footnotetext{
70 NOTÍCIAS STF. Disponível em $<$ http://www.stf.jus.br/portal/cms/verNoticiaDetalhe.asp?idConteudo=69666\&caixaBusca=N $>$. Acesso em 22 abr.2009.

$\begin{array}{llll}71 & \text { NOTÍCIAS } & \text { STF. } & \text { Disponível }\end{array}$ http://www.stf.jus.br/portal/cms/verNoticiaDetalhe.asp?idConteudo=69697\&caixaBusca=N $>$. Acesso em 22 abr.2009.
} 
Ainda afirmou que há 72 aplicações clínicas descritas com o uso de células-tronco adultas e nenhuma aplicação descrita de células-tronco embrionárias. $^{72}$

Claudio Fonteles, afirmou na audiência pública que a ação no Supremo tem um objetivo básico: "garantir o direito à vida, que é inviolável, segundo a Constituição".

“Dizer que o direito à vida é inviolável e parar, não tem sentido. Porque a pergunta necessária é: então, quando começa a vida? A partir daí eu propus esse debate ao Supremo Tribunal Federal. Propus, inclusive, que fosse feita essa audiência pública com os cientistas para provar que o direito não se basta a si mesmo".

Ainda acrescentou que o útero é apenas um ninho e que o embrião já tem vida a partir da fecundação, pois ele se auto-define e se auto-dinamiza. "Não precisamos usar esses embriões. As células-tronco adultas podem ser utilizadas com excelentes resultados para a ciência”.

E ao final concluiu: "Eu defendo a vida humana e ela começa com a fecundação, isto é fundamental. Minha luta é pela vida humana. Vamos prosseguir com o que já é certo e não com o que ainda está no escuro".73

A doutora Alice Teixeira Ferreira argumentou que não há certeza científica, de que os embriões congelados há mais de três anos seriam inviáveis e, conseqüentemente, se prestando para a pesquisa científica. Afirmou categoricamente, com base em evidências científicas, que a célula-

\footnotetext{
72 NOTÍCIAS STF. Disponível em $<$ http://www.stf.jus.br/portal/cms/verNoticiaDetalhe.asp?idConteudo=69672\&caixaBusca=N $>$. Acesso em 22 abr.2009.

73 NOTÍCIAS STF. $\quad$ Disponível em < http://www.stf.jus.br/portal/cms/verNoticiaDetalhe.asp?idConteudo=69701\&caixaBusca=N $>$. Acesso em 22 abr.2009.
} 
tronco parcialmente, ou mesmo totalmente diferenciada, pode voltar a assumir sua característica original de célula pluripotente. Essa foi a primeira demonstração comprovada, em animais, de que se pode transformar cálulastronco adultas em células com características embrionárias. A professora paulista expôs diversas pesquisas que indicam o caminho da medicina regenerativa a partir de células-tronco do cordão umbilical e sugeriu à classe médica a criação de um banco de líquido amniótico, que após o parto é dispensado, para aproveitamento futuro. Para a pesquisadora, todos os relatos provam que não há necessidade de utilizar células-tronco embrionárias, que sacrifiquem o embrião humano, face às alternativas por ela apresentadas. ${ }^{74}$

Dr. Rodolfo Acatauassú Nunes disse na audiência pública do dia 20 de abril de 2007, que "não seria respeitoso com a dignidade humana utilizar classificações didáticas para remanejar o marco inicial da vida de um ser humano e, a partir daí, passar a executar lesões físicas à sua estrutura, com a justificativa de que abaixo do período arbitrado já não haveria vida quando todas as evidências mostram o contrário". De acordo com ele, esta postura prejudica a formação do futuro médico ou de outros profissionais de saúde. "Essa aparente confusão atrapalha na transmissão do zelo pela vida humana". 75

\subsection{O Julgamento}

O dia 5 de março de 2008 foi agendado para o julgamento, pelo Plenário do Supremo Tribunal Federal (STF), da Ação Direta de Inconstitucionalidade (ADI) 3510, que questiona a Lei de Biossegurança

\footnotetext{
74 NOTÍCIAS STF. Disponível em http://www.stf.jus.br/portal/cms/verNoticiaDetalhe.asp?idConteudo=69694\&caixaBusca=N $>$. Acesso em 24 abr.2009.

75 NOTÍCIAS STF. $\quad$ Disponível em http://www.stf.jus.br/portal/cms/verNoticiaDetalhe.asp?idConteudo=69686\&caixaBusca=N $>$. Acesso em 24 abr.2009.
} 
(Lei 11.105/05, artigo $5^{\circ}$ ) em relação ao uso de células-tronco de embriões humanos para fins de pesquisa e terapia.

A então presidente do Supremo, ministra Ellen Gracie, reservou todo o dia para os debates. Após a leitura do relatório, tiveram direito a fazer sustentação oral a Procuradoria Geral da República, a Advocacia Geral da União e o Congresso Nacional, bem como as entidades interessadas, que foram admitidas como amici curiae pelo relator do processo.

A fase de sustentação oral na tribuna iniciou com o procurador-geral da República, seguido do representante da CNBB (Conferência Nacional dos Bispos do Brasil), o advogado Ives Gandra Martins, que teve quinze minutos para falar pela inconstitucionalidade da lei. Em seguida, falou o advogado-geral da União, José Antônio Toffoli, que defendeu a constitucionalidade das pesquisas com células-tronco embrionárias conforme determina o artigo $5^{\circ}$ da Lei $11.105 / 2005$ e o advogado do Congresso Nacional, Leonardo Mundim, que também se posicionou pela legalidade dos artigos da Lei 11.105/2005. Por fim, as entidades favoráveis às pesquisas - Conectas Direitos Humanos, Centro de Direitos Humanos (CDH), Movimento em Prol da Vida (Movitae) e o Instituto de Bioética, Direitos Humanos e Gênero (Anis) dividiram o tempo de 30 minutos, conforme prevê o Regimento Interno do STF, para apresentar aos ministros seus argumentos.

Após a leitura do relatório, realizada pelo ministro Carlos Ayres Britto, o procurador-geral da República, Antonio Fernando Souza, opinou pela não utilização dos embriões. Para ele, o artigo $5^{\circ}$ da Lei de Biossegurança deveria ser declarado inconstitucional pelo Plenário do Supremo Tribunal Federal. Afirmou que a pesquisa científica não seria atingida de modo expressivo pelo reconhecimento da inconstitucionalidade, 
tendo em vista a existência de outras possibilidades de atuação, "inclusive com o uso de células embrionárias".

Reafirmou que existe convicção científica consistente no sentido de que a vida humana acontece a partir da fecundação. "O embrião não é um simples amontoado de células, mas sim um ser humano na fase inicial de sua vida".

Já o advogado José Antonio Toffoli, defendeu a pesquisa com células-tronco embrionárias alegando que o Estado deve sempre agir sob a ótica prática e, por isso, garantir a possibilidade de pessoas com determinadas doenças virem a se curar por meio de descobertas feitas a partir de estudos com células-tronco oriundas de embriões humanos.

Argumentou que se o Estado não tem como assegurar o direito à vida para os embriões congelados, ele não pode reconhecer a existência desse direito. "Se embrião congelado tem direito à vida, poderá o Estado obrigar a mulher a conceber o embrião?".

Também disse que a legislação brasileira diferencia claramente a vida humana do feto, dando, como exemplo, a diferenciação das penas para os crimes de aborto (mais amenas) e para os crimes de homicídio. " $A$ legislação brasileira não trata o feto no útero da mulher como pessoa humana, mas como feto com expectativa de direito".

Ele explicou que a personalidade jurídica, no Brasil, começa com o nascimento com vida. Quanto ao feto, há expectativa de direito. Nesse sentido, não haveria lógica em se reconhecer direito à vida para um embrião congelado. $^{76}$

\footnotetext{
$\overline{76}$ NOTÍCIAS, STF. Disponível em $<$ http: $/ /$ www.stf.jus.br/portal/cms/verNoticiaDetalhe.asp?idConteudo=84332\&caixaBusca=N $>$. Acesso em 28 abr.2009.
} 
Leonardo Mundim, advogado do Congresso Nacional, falou sobre o fato de só poderem ser usados para as pesquisas os embriões considerados inviáveis, "inaptos a gerar um futuro ser humano".Também salientou outro ponto importante, que é o dever dos comitês de ética das instituições aprovarem, previamente, os projetos.

Para ele, a rigorosa regulamentação das pesquisas com célulastronco embrionárias garantiria o controle ético dos procedimentos. Já a proibição poderia significar apenas "um fechar de olhos" levando à clandestinidade de pesquisas científicas.

Por fim, o advogado disse entender que não se pode reconhecer como vida um embrião que ainda não está nidado, ou seja, acoplado no útero humano e que o fato de ainda não se terem conclusões definitivas das pesquisas não deve motivar que elas sejam proibidas, mas sim estimuladas. $^{77}$

O advogado Oscar Vilhena Vieira falou em nome das entidades Conectas Direitos Humanos e Centro de Direitos Humanos (CDH). Segundo ele, um embrião inviável à reprodução humana não poderia ser equiparável, para fins do direito constitucional brasileiro, a uma pessoa que tem relações afetivas e emocionais, com "potencialidade de autonomia".

"Não podemos comparar um conjunto de células que tem quatro ou cinco dias, que são destituídas de um sistema nervoso central com uma pessoa que nós nos relacionamos, que nós amamos ou que, eventualmente,

\footnotetext{
77 NOTÍCIAS STF. Disponível em $<$ http://www.stf.jus.br/portal/cms/verNoticiaDetalhe.asp?idConteudo=84331\&caixaBusca=N $>$. Acesso em 28 abr.2009.
} 
odiamos, mas que é uma pessoa e que tem direitos garantidos pela Constituição" 78

O advogado destacou que a Lei não afronta à Constituição "porque objetiva a otimização do direito à vida daqueles que perderam as suas expectativas". De acordo com ele, a ciência pode beneficiar muitas pessoas, por meio do resultado das pesquisas com células-tronco embrionárias. "Se isso for possível, nós estaremos dando um avanço espetacular em relação à otimização do direito à vida e da dignidade humana”.

Já o advogado Luís Roberto Barroso representou o Movimento em Prol da Vida (Movitae) e Instituto de Bioética, Direitos Humanos e Gênero (Anis) que também se posicionaram favoravelmente às pesquisas com células-tronco embrionárias.

Ele acredita que a lei de Biossegurança é equilibrada e razoável, na medida em que prevê que os embriões congelados somente serão destinados à pesquisa se os casais que doaram o material genético autorizarem. " $E$ ' disso que se trata aqui: pluralismo, diversidade e tolerância”.

Considerou que, se o embrião não é implantado, não é vida em potencial. "Um embrião congelado há mais de três anos sem perspectiva de implantação em um útero materno não tem o tipo de proteção jurídica que se pretende na petição inicial”. 79

O julgamento da Ação Direta de Inconstitucionalidade 3510 foi suspenso no dia 05 de março de 2008 com o pedido de vista do ministro Menezes Direito. Entretanto a ministra Ellen Gracie antecipou seu voto e

\footnotetext{
78 NOTÍCIAS STF. Disponível em $<$ http://www.stf.jus.br/portal/cms/verNoticiaDetalhe.asp?idConteudo=84386\&caixaBusca=N $>$. Acesso em 28 abr.2009. 79 NOTÍCIAS STF. Disponível em< http://www.stf.jus.br/portal/cms/verNoticiaDetalhe.asp?idConteudo=84386\&caixaBusca=N $>$. Acesso em 28 abr.2009.
} 
acompanhou o relator julgando improcedente a ação. O Supremo Tribunal Federal (STF) retomou nos dias 28 e 29 de Maio de 2008 o julgamento da (ADI) 3510 .

Por maioria de votos, os ministros julgaram improcedente a Ação Direta de Inconstitucionalidade (ADI) 3510, ajuizada pela Procuradoria Geral da República para contestar o uso de embriões humanos para pesquisas.

Votaram pela improcedência da ação os ministros Carlos Ayres Britto (relator), Ellen Gracie, Cármen Lúcia Antunes Rocha, Joaquim Barbosa, Marco Aurélio e Celso de Mello.

Igualmente favoráveis às pesquisas, porém com restrições, em diferentes níveis, votaram os ministros Carlos Alberto Menezes Direito, Ricardo Lewandowski, Eros Grau, Cezar Peluso e Gilmar Mendes.

\subsubsection{Voto do Ministro Carlos Ayres Britto}

$\mathrm{O}$ ministro Carlos Ayres Britto votou favoravelmente às pesquisas com células-tronco de embriões e, ao ler o voto, disse que óvulo já fecundado, mas congelado há mais de três anos, tem viabilidade muito baixa, praticamente nula, de se tornar vida humana, porém tem potencial para se transformar em tecidos do corpo humano, o que não ocorre com as células-tronco adultas. ${ }^{80}$

\footnotetext{
$80 \quad$ NOTÍCIAS STF. Disponível em <http://www.stf.jus.br/portal/cms/verNoticiaDetalhe.asp?idConteudo=84380\&caixaBusca=N $>$. Acesso em 28 abr.2009.
} 
Para o ministro, a Lei de Biossegurança não impõe "um frio assassinato" aos embriões, mas possibilita uma solução ao "infortúnio alheio" de pessoas com doenças hoje incuráveis.

Em seu voto o ministro qualificou como "perfeito" e "bem concatenado bloco normativo" o dispositivo questionado, ao lembrar que ele apresenta uma série de condicionantes para o aproveitamento das células-tronco embrionárias "in vitro" como a restrição do uso para pesquisa àquelas não aproveitadas para fins reprodutivos; àquelas que não tiverem viabilidade; àquelas que estejam congeladas por três anos ou mais; e àquelas que, congeladas, completarem três anos nesse estágio. Também mencionou a necessidade de consentimento do casal doador para realização de pesquisas científicas para tratamento de doenças; o exame de mérito pelos comitês de ética e pesquisa; e a vedação de sua comercialização.

Ayres Britto afirmou ainda que a Constituição Federal, quando se refere a direitos e garantias constitucionais, fala do indivíduo pessoa, ser humano, já nascido, desconsiderando o estado de embrião e feto, mas a legislação infraconstitucional cuidou do direito do nascituro, do ser que está a caminho do nascimento

Defendeu a tese de que para existir vida humana é preciso que o embrião tenha sido implantado no útero humano. Não há como sobreviver sem estar implantado no útero materno com a participação ativa da mãe. O zigoto é a primeira fase do embrião humano, a célula-ovo ou célula-mãe, mas representa uma realidade distinta da pessoa natural, porque ainda não tem cérebro formado.

Reportou-se ao artigo 226, parágrafo $7^{\circ}$, da Constituição, para sustentar que o casal tem direito ao planejamento familiar e disse que a Constituição, em momento algum, determina que a geração de filhos tenha 
que ser pelo meio natural. Portanto, segundo ele, o casal tem direito a recorrer à fertilização "in vitro" para gerar filhos. Porém neste processo, o casal não é obrigado a utilizar todos os óvulos fecundados.

Também fez menção ao disposto no parágrafo $4^{\circ}$ do artigo 199, CF, que atribui à lei ordinária dispor sobre condições e requisitos para a remoção de órgãos, tecidos ou substâncias para fins de transplante, citou diversos artigos da Constituição que tratam do direito à saúde (artigos 196 a 200) e à obrigatoriedade do Estado de garanti-la e também mencionou o Capítulo IV do Título VIII da Constituição, que trata do incentivo ao desenvolvimento e à pesquisa científica no País (artigos $218 \mathrm{e}$ 219, CF), para defender as pesquisas científicas com as células-tronco embrionárias humanas. ${ }^{81}$

\subsubsection{Voto da Ministra Ellen Gracie}

Apesar do julgamento da Ação Direta de Inconstitucionalidade 3510 ter sido suspenso no dia 05 de março de 2008 com o pedido de vista do ministro Menezes Direito, a ministra Ellen Gracie antecipou seu voto e acompanhou o relator julgando improcedente a ação. Ela assinalou que a ordem jurídica nacional atribui a qualificação de pessoa ao nascido com vida. Ressaltou que

"Por outro lado, o pré-embrião não se enquadra na condição de nascituro, pois a este a própria denominação o esclarece bem, se pressupõe a possibilidade, a probabilidade de vir a nascer, o que não acontece com esses embriões inviáveis ou destinados ao descarte". 82

\footnotetext{
$81 \quad$ NOTÍCIAS, STF. Disponível em $<$ http://www.stf.jus.br/portal/cms/verNoticiaDetalhe.asp?idConteudo=84390\&caixaBusca=N $>$. Acesso em 28 abr.2009.

82 NOTÍCIAS, STF. $\quad$ Disponível em http://www.stf.jus.br/portal/cms/verNoticiaDetalhe.asp?idConteudo=89264\&caixaBusca=N $>$. Acesso em 28 abr.2009.
} 


\subsubsection{Voto do Ministro Menezes Direito ${ }^{83}$}

O ministro Menezes Direito afirmou que a análise da constitucionalidade da lei que permite o uso dessas células não é uma questão religiosa, mas jurídica, que abrange a compatibilidade da lei com os direitos constitucionais à vida e à dignidade da pessoa humana.

Afirmou que as promessas atribuídas às pesquisas com célulastronco embrionárias ainda não têm resultados práticos, mas algumas pesquisas com células-tronco adultas já possibilitam o uso em terapias. $\mathrm{O}$ ministro disse entender que é precoce qualquer sugestão de aplicação prática dos resultados das pesquisas com células-tronco embrionárias.

O ministro citou Aristóteles para afirmar que deve se afastar a idéia de que embrião não será alguém fora do útero. “O embrião foi gerado para ser, e não para não ser. É um ser em potência e essência, em ininterrupta atualização”.

O ministro julgou parcialmente procedente a ADI 3510. Segundo ele, as pesquisas com as células-tronco podem ser mantidas, mas sem prejuízo para os embriões humanos viáveis, ou seja, sem que sejam destruídos.

Votou no sentido de que as células-tronco embrionárias são vida humana e que qualquer destinação delas a finalidade diversa que a reprodução humana viola o direito à vida, previsto no caput do artigo $5^{\circ}$ da Constituição Federal.

\footnotetext{
$83 \quad$ NOTÍCIAS, STF. $\quad$ Disponível em http://www.stf.jus.br/portal/cms/verNoticiaDetalhe.asp?idConteudo=89917\& caixaBusca=N $>$. Acesso em 30 abr.2009.
} 
Também propôs mais restrições ao uso das células-tronco embrionárias, assim como um maior rigor na fiscalização por acreditar que há falta de controle nos trabalhos realizados nas clínicas que fazem fertilização "in vitro".

As propostas feitas pelo Ministro são as seguintes:

"1 - no caput do artigo $5^{\circ}$ (que autoriza as pesquisas com células-tronco embrionárias), declarar parcialmente a inconstitucionalidade, sem redução de texto, dando interpretação conforme a Constituição, "para que seja entendido que as células-tronco embrionárias sejam obtidas sem a destruição do embrião e as pesquisas, devidamente aprovadas e fiscalizadas pelo órgão federal, com a participação de especialistas de diversas áreas do conhecimento, entendendo-se as expressões 'pesquisa' e 'terapia' como pesquisa básica voltada para o estudo dos processos de diferenciação celular e pesquisas com fins terapêuticos".

2 - Ainda no caput do artigo $5^{\circ}$, declarar parcialmente a inconstitucionalidade, sem redução do texto, "para que a fertilização 'in vitro' seja entendida como modalidade terapêutica para cura da infertilidade do casal, devendo ser empregada para fins reprodutivos, na ausência de outras técnicas, proibida a seleção de sexo ou características genéticas; realizada a fertilização de um máximo de quatro óvulos por ciclo e igual limite na transferência, ou proibição de redução embrionária, vedado o descarte de embriões, independentemente de sua viabilidade, morfologia ou qualquer outro critério de classificação, tudo devidamente submetido ao controle e fiscalização do órgão federal".

3 - No inciso I , declarar parcialmente a inconstitucionalidade, sem redução de texto, para que a expressão "embriões inviáveis" seja considerada como "referente àqueles insubsistentes por si mesmos, assim os que comprovadamente, de acordo com as normas técnicas estabelecidas pelo órgão federal, com a participação de especialistas de diversas áreas do conhecimento, tiveram seu desenvolvimento interrompido, por ausência espontânea de clivagem, após período, no mínimo, superior a 24 horas, não havendo, com relação a estes, restrição quanto ao método de obtenção das células-tronco".

4 - No inciso II, declarar a inconstitucionalidade, sem redução de texto,"para que sejam considerados embriões congelados há três anos ou mais, na data da publicação da Lei 11.105/2005 (Lei da Biossegurança), ou que, já congelados na data da publicação da Lei 11.105, depois de completarem três anos de congelamento, dos quais, com o consentimento informado, prévio e expresso dos genitores, por escrito, somente poderão ser retiradas células-tronco por meio que não cause suas destruição".

5 - No parágrafo primeiro, declarar parcialmente a inconstitucionalidade, sem redução de texto,"para que seja entendido que o consentimento é um consentimento informado, prévio e expresso por escrito pelos genitores". 6 - No parágrafo segundo, declarar a inconstitucionalidade, sem redução de texto, "para que seja entendido que as instituições de pesquisa e serviços de saúde que realizem pesquisa com terapia com células-tronco embrionárias humanas deverão submeter, previamente, seus projetos 
também à aprovação do órgão federal, sendo considerado crime a autorização para utilização de embriões em desacordo com o que estabelece esta decisão, incluídos como autores os responsáveis pela autorização e fiscalização". ${ }^{84}$

\subsubsection{Voto da Ministra Cármen Lúcia ${ }^{85}$}

A ministra Cármen Lúcia disse em seu voto não ver violação do direito à vida a garantia das pesquisas com as células-tronco embrionárias. Assim votou pela improcedência da Ação Direita de Inconstitucionalidade (ADI 3510).

Para a ministra, as pesquisas com células-tronco embrionárias são "uma forma de dignificação da vida humana". Afirmou que os estudos com as células-tronco embrionárias podem não ser a garantia de cura para doenças degenerativas, mas que "a não-pesquisa é a certeza de ausência de resultados".

Afirmou, também, que o embrião não implantado no útero de uma mulher é descartado o que equivaleria a transformar esses embriões em um "lixo genético", negando-lhes a possibilidade de serem utilizados para garantir "a dignidade da vida humana" por meio de pesquisas com potencial para descobrir o tratamento de diversas doenças.

\footnotetext{
84 NOTÍCIAS, STF. Disponível em $<$ http://www.stf.jus.br/portal/cms/verNoticiaDetalhe.asp?idConteudo=89676\&caixaBusca=N $>$. Acesso em 30 abr.2009.

85
NOTÍCIAS, STF. Disponível em $<$ http://www.stf.jus.br/portal/cms/verNoticiaDetalhe.asp?idConteudo=89736\&caixaBusca=N $>$. Acesso em 30 abr.2009.
} 


\subsubsection{Voto do Ministro Ricardo Lewandowski}

O ministro Lewandowski votou pela procedência em parte da ADI 3510. Ele é a favor das pesquisas com células-tronco embrionárias, porém acredita que deve haver restrições a essas pesquisas.

Sua interpretação é no sentido de que:

“1) Artigo $5^{\circ}$, caput - as pesquisas com células-tronco embrionárias somente poderão recair sobre embriões humanos inviáveis ou congelados logo após o início do processo de clivagem celular sobejantes de fertilizações in vitro realizadas com o fim único de produzir o número de zigotos estritamente necessário para a reprodução assistida de mulheres inférteis.

2) Inciso I, do artigo $5^{\circ}$ - o conceito de inviável compreende apenas os embriões que tiverem o seu desenvolvimento interrompido por ausência espontânea de clivagem após período superior a 24h, contados da fertilização dos zoócitos.

3) Inciso II, do artigo $5^{\circ}$ - as pesquisas com embriões congelados são admitidas desde que não sejam destruídos, nem tenham seu potencial de desenvolvimento comprometido.

4) Parágrafo $1^{\circ}$, do artigo $5^{\circ}$ - a realização de pesquisas com células tronco embrionárias exige o consentimento "livre e informado dos genitores, formalmente exteriorizado".

5) Parágrafo $2^{\circ}$, do artigo $5^{\circ}$ - os projetos de experimentação com embriões humanos, além de aprovados pelos comitês de éticas das instituições de pesquisa e serviços de saúde por eles responsáveis, devem ser submetidos a prévia autorização e permanente fiscalização dos órgãos públicos mencionados na Lei 11105, de 24 de março de 2005."

\subsubsection{Voto do Ministro Eros Grau}

O ministro votou pela constitucionalidade do artigo $5^{\circ}$ da Lei $11.105 / 2005$.

Afirmou que devem ser estabelecidos limites para que se impeça a manipulação genética e fez três ressalvas. Ele propôs a criação de um 
comitê central do Ministério da Saúde para controlar as pesquisas, além de só permitir que sejam fertilizados quatro óvulos por ciclo e que a obtenção de células-tronco embrionárias seja realizada a partir de óvulos fecundados inviáveis, ou sem danificar os viáveis.

Em seus argumentos, o ministro Eros Grau ressaltou que o embrião faz parte do gênero humano, sendo assim ele tem a proteção da sua dignidade garantida pela Constituição, "que lhe assegura ainda o direito à vida". 87

\subsubsection{Voto do Ministro Cezar Peluso ${ }^{88}$}

$\mathrm{O}$ voto do ministro Cezar Peluso foi favorável às pesquisas com células-tronco embrionárias. Para ele, essas pesquisas não ferem o direito à vida, já que os embriões congelados não equivalem a pessoas. Ele acredita que a vida é resultado de uma sucessão contínua de mudanças e, por isso, ela não existe no ser que não tenha capacidade de mover-se por si mesmo, como ocorre com os embriões congelados, que têm seu processo de desenvolvimento suspenso.

“Os embriões congelados não são portadores de vida nem equivalem a pessoas, não vejo como, nem por onde, as pesquisas ofendem o chamado direito à vida”.

Assim como outros ministros, ressaltou a importância da fiscalização rigorosa nesses tipos de pesquisas. Disse que o Congresso Nacional deve aprovar instrumentos legais para efetivar essa fiscalização.

\footnotetext{
$86 \quad$ NOTÍCIAS, $\quad$ STF. $\quad$ Disponível em $<$ http://www.stf.jus.br/portal/cms/verNoticiaDetalhe.asp?idConteudo=89739\&caixaBusca=N $>$. Acesso em 30 abr.2009.

87 NOTÍCIAS

STF.

Disponível em

http://www.stf.jus.br/portal/cms/verNoticiaDetalhe.asp?idConteudo=89767\&caixaBusca=N $>$. Acesso em 30 abr. 2009.

88 NOTÍCIAS, STF. Disponível em < http://www.stf.jus.br/portal/cms/verNoticiaDetalhe.asp?idConteudo=89763\&caixaBusca=N $>$. Acesso em 30 abr.2009.
} 
Ele julgou que há um o contra-senso no argumento do grupo contrário as pesquisas, já que não seria ilegal gerar vida artificialmente, mas o estudo com embriões gerados artificialmente, por fertilização in vitro, não poderia ser utilizado para salvar vidas.

\subsubsection{Voto do Ministro Marco Aurélio ${ }^{89}$}

O ministro Marco Aurélio votou pela improcedência da Ação Direta de Inconstitucionalidade (ADI) 3510.

Afirmou que o artigo $5^{\circ}$ da Lei de Biossegurança, impugnado na ADI proposta pelo ex-procurador-geral da República Cláudio Fonteles, "está em harmonia com a Constituição Federal, notadamente com os artigos $1^{\circ}$ e $5^{\circ}$ e com o princípio da razoabilidade”.

Iniciou seu voto chamando atenção para o risco de o STF assumir o papel de legislador, ao propor restrições a uma lei que, segundo ele, foi aprovada com apoio de $96 \%$ dos senadores e $85 \%$ dos deputados federais o que sinaliza a sua "razoabilidade". Em sua visão, o artigo de uma lei ou é constitucional, ou não o é, mas não cabe ao Supremo propor-lhe complementações.

“O início da vida não pressupõe só a fecundação, mas a viabilidade da gravidez, da gestação humana. Dizer que a Constituição protege a vida uterina já é discutível, quando se considera o aborto terapêtico ou o aborto de filho gerado com violência”. Afirmou que a possibilidade jurídica depende do nascimento com vida.

\footnotetext{
89 NOTÍCIAS, STF. Disponível em $<$ http://www.stf.jus.br/portal/cms/verNoticiaDetalhe.asp?idConteudo=89857\&caixaBusca=N $>$. Acesso em 30 abr.2009.
} 
Considerou por fim que seria muito egoísmo jogar no lixo embriões que poderiam ser usados para pesquisar a cura de diversas doenças.

\subsubsection{Voto do Ministro Joaquim Barbosa ${ }^{90}$}

O ministro Joaquim Barbosa acompanhou integralmente o voto do relator, julgando pela improcedência da ADI 3510.

Ele usou como exemplo o panorama de outros países como Espanha, Bélgica e Suíça, dizendo que esse tipo de pesquisa é permitida com restrições semelhantes às nossas, como a obrigatoriedade de que os estudos atendam ao bem comum, que os embriões utilizados sejam inviáveis à vida e provenientes de processos de fertilização in vitro e que haja um consentimento expresso dos genitores para o uso dos embriões nas pesquisas.

Para Joaquim Barbosa, a proibição das pesquisas com células embrionárias, nos termos da lei, "significa fechar os olhos para o desenvolvimento científico e os beneficios que dele podem advir”.

\subsubsection{Voto do Ministro Celso de Mello ${ }^{91}$}

O ministro considerou constitucional a Lei de Biossegurança (Lei 11.105/05) sobre a realização de pesquisas com células-tronco embrionárias, acompanhando o relator.

Segundo o ministro, o conceito do início da vida, assim como o conceito de morte, não são questões científicas e biológicas, mas filosóficas

\footnotetext{
90 NOTÍCIAS, STF. Disponível em http://www.stf.jus.br/portal/cms/verNoticiaDetalhe.asp?idConteudo=89917\&caixaBusca $=\mathrm{N} \quad>$. Acesso em 30 abr.2009.
} 
e morais, definidas arbitrariamente pela legislação de cada país, em consonância com os costumes e com a cultura da população.

"Ocorre, sim, o início da vida com a fecundação, mas o blastocisto está muito longe de ser um ser humano". "Esse notável voto [do relator] representa a aurora de um novo tempo impregnado de esperança para aqueles abatidos pela angústia da incerteza”.

Ele ressaltou a importância da República ser laica ao dizer que o direito não se submete à religião "e as autoridades incumbidas de aplicá-lo devem despojar-se de pré-compreensões em matéria confessional em ordem a não fazer repercutir sob o processo de poder, quando no exercício de suas funções, qualquer que seja o domínio de sua incidência as suas próprias convicções religiosas”.

\subsubsection{Voto do Ministro Gilmar Mendes $^{92}$}

O ministro Gilmar Mendes, último a proferir o voto, julgou a ação improcedente, declarando a constitucionalidade do artigo $5^{\circ}$ da Lei 11.105/05, porém assim como os ministros Carlos Alberto Menezes Direito, Ricardo Lewandowski, Eros Grau e Cezar Peluso, fez a ressalva da necessidade de controle das pesquisas com células-tronco embrionárias. Ele sugeriu um Comitê Central de Ética e Pesquisa vinculado ao Ministério da Saúde para exercer a fiscalização, para atender o texto constitucional.

Fez críticas à Lei 11.105/2005, por entender que a norma é deficiente para regular a questão das pesquisas.

\footnotetext{
$91 \quad$ NOTÍCIAS, $\quad$ STF. $\quad$ Disponível em $<$ http://www.stf.jus.br/portal/cms/verNoticiaDetalhe.asp?idConteudo=89906\&caixaBusca=N $>$. Acesso em 30 abr.2009.

92 NOTÍCIAS, STF. $\quad$ Disponível em < http://www.stf.jus.br/portal/cms/verNoticiaDetalhe.asp?idConteudo=89910\&caixaBusca=N $>$. Acesso em 30 abr.2009.
} 
Citou a existência do Decreto 5.591/05, que regulamenta a Lei de Biossegurança, mas disse ser insuficiente. Segundo Gilmar Mendes, a lei não cria de forma expressa as atribuições de um legítimo comitê central de ética para controlar as pesquisas com células-tronco de embriões humanos.

Apesar de julgar a lei insuficiente no aspecto da fiscalização, o ministro argumentou que não cabe ao caso a declaração de inconstitucionalidade do artigo $5^{\circ}$ da Lei de Biossegurança, mas tão somente dar interpretação conforme a Constituição, ao dispositivo. 


\section{Conclusão}

A revolução do conhecimento trouxe para o centro da reflexão contemporânea, novas realidades biológicas, fazendo com que todos os princípios e definições jurídicas, como pessoa humana e capacidade jurídica, fossem repensadas, para se adequar a essa nova realidade científica.

Com o julgamento da ADI 3510 notou-se que o foco da discussão sobre o uso de células-tronco de embriões humanos em pesquisas científicas, que envolve a questão sobre quando se inicia a vida, não poderia ser dada pelo Judiciário. Essa questão provavelmente nunca será superada, uma vez que, durante décadas da nossa história o conceito de início e fim da vida humana esteve presente nos campos das ciências filosóficas e religiosas, apresentando peculiaridades e noções fundamentais para a construção do conceito de pessoa, e notou-se que conforme a sociedade evoluía o entendimento de quando se inicia a vida no campo das ciências filosóficas e religiosas mudava.

Quando essa discussão foi tratada pela comunidade científica, verificou-se também que nem eles têm uma resposta única. Quando tem início a vida humana? Essa pergunta tem pelo menos quatro diferentes respostas possíveis, todas válidas perante a medicina e biologia. Todas com limitações e com alcances variados. Assim, a questão central colocada diante do Supremo Tribunal Federal não tem uma resposta exata. Como foi demonstrado no decorrer desta monografia, não há um consenso científico a respeito do início da vida humana.

Assim, ao invés de tentar desvendar o debate de quando se inicia a vida e conseqüentemente se o princípio da dignidade da pessoa humana vale para o embrião humano, devem ser buscados critérios de praticidade, 
que indiquem como o embrião deve ser tratado. Significa deixar a reflexão unicamente teórico-abstrata de lado, para investir na definição de normas de boa conduta em relação ao uso deste embrião humano, definir o destino dos óvulos fecundados que fatalmente seriam destruídos e que poderiam ser aproveitados na tentativa de descobertas de cura de inúmeras doenças.

Utilizando o entendimento de que melhor seria definir normas de boa conduta em relação ao embrião humano do que definir se o embrião inviável produzido em laboratório é ou não pessoa humana, entendemos como de acordo com a expectativa da sociedade a decisão final do Supremo Tribunal Federal ao julgar improcedente a ADI 3510.

Um fato curioso no julgamento da ADI 3510 foi o de que alguns Ministros, como o Ministro Menezes Direito, surpreendentemente ao invés de julgar pela procedência ou improcedência da ADI, declarou que o texto legal poderia ser aceitável desde que fosse dado a ele uma interpretação conforme a Constituição, sem redução do texto. Dando continuidade ao voto, ele estabeleceu o que deveria ser entendido no art. $5^{\circ}$ e parágrafos da Lei de Biossegurança.

Observando o minucioso conteúdo das seis condições impostas pelo Ministro, percebe-se que, de fato, ele não está interpretando a lei, mas sim legislando. Não está esclarecendo o sentido de algum termo equívoco ou obscuro da lei, mas elaborando uma nova lei, que é função do Legislativo, e não da Corte Constitucional.

Assim como o Ministro Menezes Direito, os Ministros Eros Grau e Ricardo Lewandowski seguiram essa técnica.

Já o Ministro Marco Aurélio, em seu voto, disse que vê com restrições a denominada interpretação conforme a Constituição, por 
entender que há risco de, a tal título, redesenhar-se a norma em exame, assumindo o Supremo Tribunal Federal, contrariando e não protegendo a Constituição Federal, o papel de legislador positivo. Também afirmou que é de todo impróprio o STF, ao julgar, faça recomendações. O STF não é um órgão de aconselhamento, no julgamento de qualquer ADI só há duas alternativas: ou declara a constitucionalidade ou a inconstitucionalidade total ou parcial, do ato normativo abstrato atacado.

Entendemos que se fosse acatada a proposição da ADI 3510, tem-se que desde o estabelecimento das técnicas de fertilização in vitro no Brasil estaríamos diante de crimes em larga escala, já que se a técnica de fertilização in vitro seguir a resolução do Conselho Federal de Medicina (Resolução CFM 1.358/92) que cuida do tema de reprodução assistida, de cada tentativa de reprodução assistida apenas quatro de quinze embriões são transferidos para o útero materno, restando mais de dez óvulos fertilizados não transferidos, também denominados pré-embriões ou embriões, uma vez que nas técnicas de fertilização utilizadas hoje em dia são obtidos entre dez a quinze óvulos fertilizados.

Na maioria dos países onde são realizadas as técnicas de reprodução humana assistida, é feita a produção supranumerária de pré-embriões e em todos esses países esses pré-embriões não são considerados ainda um ser humano, assim como o descarte desse material não constitui assassinato. É desse material de que se trata o tema abordado pela ADI 3510.

Deste modo, a questão levantada pela ADI 3510 inviabilizaria ou restringiria gravemente as possibilidades de fertilização in vitro no Brasil

Acatar a tese contida na ADI 3510 representaria entender como criminosos milhares de pessoas que trabalham para trazer vidas humanas ao mundo por meio das técnicas de fertilização in vitro. Entendemos que 
significaria também acabar com as esperanças de milhões de pessoas que estão esperando pela cura de doenças que hoje são consideradas incuráveis, assim como eliminar a esperança de casais inférteis no Brasil.

Além disso, acreditamos que um embrião produzido em laboratório, sem condições para implantação em um útero de uma mulher, ou nos termos da lei, um embrião inviável, que seria descartável, não é uma pessoa humana.

Acreditamos também, que o contido no artigo $5^{\circ}$ da Lei de Biossegurança, objetiva preservar o fundamento de Dignidade da Pessoa Humana, uma vez que visa possibilitar a cura de diversas doenças, devolvendo o status de vida digna a várias pessoas que sofrem de doenças que hoje são consideradas incuráveis. 


\section{Bibliografia:}

AGENCIA LUSA. Conselho de ética português da sinal amarelo à clonagem. Disponível em <lhttp://www.agencialusa.com.br/index.php?iden=873>. Acesso em 24 ma.2009.

BARBOSA, Heloísa Helena. Princípios do Biodireito. Disponível em $<$ http://www.espdh.hpg.com.br/texto7.pdf> Acesso em 30 mar. 2009.

BARTH, Wilmar Luiz.CélulasTtronco e Bioética: O Progresso Biomédico e os Desafios Éticos. Porto Alegre: Edipucrs, 2006. 331 p.

BARRETO, Vicente de Paulo.A idéia de Pessoa Humana e os Limites da Bioética. In: BARBOZA, Heloísa Helena; MEIRELLES, Jussara Maria Leal; BARRETO, Vicente de Paulo (org). Novos temas de Biodireito e Bioética.Rio de Janeiro/ São Paulo: Renovar,2003.257 p.

BARROSO, Luiz Roberto.Pedido de ingresso como amicus curiae. Disponível em $<$ http://www.lrbarroso.com.br/pt/noticias/minuta_amicus_curiae_lrb_30s et05.pdf $>$ Acesso em 19 mar.2009.

BARROSO, Luís Roberto. A Defesa da constitucionalidade das pesquisas com células-tronco

embrionárias.

Disponível em $<$ http://www.idp.org.br/index.php?op=stub\&id=9\&sc_1=60>. Acesso em 30 mar.2009. 
BRAGA, Kátia Soares; DINIZ, Débora. Anexo ao Memorial formulado pelo amicus curiae: ANIS: Instituto de Bioética, Direitos Humanos e Gênero. Disponível em: <

http://www.ccr.org.br/uploads/noticias/adi_3510_memorial_anis_2.pdf $>$. Acesso em 23 mar. 2009.

CANÇÃO NOVA NOTÍCIAS. Obama libera pesquisas com células-tronco embrionárias.Disponível em < http://noticias.cancaonova.com/noticia.php?id=272469>. Acesso em 24 mar.2009.

CATANA, Tereza Oliveira; SOUZA, Vinícius Roberto Prioli de. Célulastronco e o Direito brasileiro. Boletim Jurídico, Uberaba/MG, a. 4, no 183. Disponível em: <http://www.boletimjuridico.com.br/ doutrina/texto.asp?id=1359> Acesso em: 17 mar. 2009.

DEFESADAVIDA.Notícias da defesa da vida.. Disponível em http://www.defesadavida.com.br/noticias_040101.htm. Acesso em 26mar.2009.

DINIZ, Debora. Em Benefício da Coletividade - Células-Tronco. O Estado de S. Paulo,

São Paulo, 14 out. 2007. Caderno Aliás, p. 3.

GRAIEB, Carlos. STF e a decisão: pesquisas com células-tronco é constitucional. Disponível em < http://arquivoetc.blogspot.com/2008/05/stfdeciso-pesquisa-com-clulas-tronco.html $>$ Acesso em 23 mar.2009. 
GLOBO.COM.Obama libera pesquisas com células-tronco com dinheiro federal $\quad$ Eos.$\quad$ Disponível em< http:/g1.globo.com/Noticias/Ciencia/0,,MUL1034916-5603,00OBAMA+LIBERA+PESQUISA+COM+CELULASTRONCO+COM+DIN HEIRO+FEDERAL+NOS+EUA.html>. Acesso em 24 mar.2009

INSTITUTO CELULAR DE CARDIOLOGIA.Terapia Celular. Disponível em $<$ http://www.incl.rj.saude.gov.br/incl/celula-tronco/index.asp $>$. Acesso em 29 abr.2009

JUSBRASIL.Voto de Gilmar Mendes. Disponível em < http://www.jusbrasil.com.br/noticias/17940/leia-voto-de-gilmar-mendessobre-pesquisas-com-celulas-tronco>. Acesso em 26 marc. 2009

Notícias STF, disponível em < http://www.stf.jus.br/portal/cms/listarNoticiaSTF.asp >. Acesso em 23 mar.2009.

O VERBO.Congresso Espanhol aprova a clonagem terapêutica.Disponível em< http://www.overbo.com.br/portal/2007/06/15/3692/>.Acesso em 25 mar.2009.

O ESTADO DE SÃO PAULO. Alemanha aprova lei que Facilita Pesquisa com Células-Tronco. Disponível em http://www.dwworld.de/dw/article/0,,3261145,00.html >Acesso em 24 mar.2009.

PESSINI, Leo; BARCHIFONTAINE, Christian de Paul. Problemas atuais de Bioética.São Paulo: Edições Loyola, 2008. 774 p. 
PINHEIRO, Aline; Não cabe a Constituição definir o que é vida, diz especialista. Disponível em <http://www.conjur.com.br/2005-nov06/nao_cabe_lei_definir_vida_especialista>. Acesso em 13 abr. 2009.

PIOVESAN, Flávio. Temas de Direitos Humanos. São Paulo: MAX Limonad, 2003.448p.

SANTOS,Ricardo Ribeiro dos Santos; SOARES, Milena Botelho Pereira. $A$ importância da utilização de células-tronco embrionárias e o direito de doação de embriões. Disponível em <http://www.ghente.org/temas/celulastronco/ricardo_ribeiro_e_milena.pdf> Acesso em 16 mar. 2009.

SCARLET, Ingo Wolfgang. Dignidade da Pessoa Humana e Direitos Fundamentais. Porto Alegre:Livraria do Advogado, 2004.158p.

VIEIRA, Alexandra.Células-tronco: o que são e para que servem. Disponível em < http://noticias.terra.com.br/ciencia/interna/0,OI472268EI1434,00.html> . Acesso em 19 mar. 2009.

ZAGO, Marco Antônio; COVAS, Tadeu Dimas. Células-Tronco: A Nova Fronteira da Medicina. São Paulo: Atheneu, 2006. 245 p. 


\title{
Anexo I
}

\author{
AÇÃo Direta de InCONSTITUCIONALIDADE N. 3.510 \\ Anexo ao Memorial \\ Formulado PELO AMICUS CURIAE \\ Anis: Instituto de Bioética, Direitos Humanos E GÊNERo \\ Em Defesa das Pesquisas com Células-Tronco Embrionárias \\ (Constitucionalidade do Artigo $5^{\circ}$ da Lei n. 11.105/2005) \\ Parte I \\ A Controvérsia do Artigo $5^{\circ}$ da Lei de Biossegurança \\ Parte II \\ Quadro Comparativo Internacional
}

Parte III

Liberdade Acadêmica

Conclusões

Anexo

Mapa - Panorama de 25 Países

2

Exmo Sr. Ministro Carlos Ayres Britto - Ministro Relator da ADIn n. 3.510

A Anis: Instituto de Bioética, Direitos Humanos e Gênero, associação civil sem fins lucrativos, com sede na CLSW 304 Bloco B sala 134, Brasília-DF, admitida como amicus curiae na presente ação direta de inconstitucionalidade, complementa com novas informações o Memorial apresentado em 20 de abril de 2007 para Audiência Pública realizada pelo Supremo Tribunal Federal. ${ }^{93}$

\section{Parte I}

\section{A Controvérsia do Artigo $5^{\circ}$ da Lei de Biossegurança}

1. A ADIn contesta o art. $5^{\circ}$ da Lei n. 11.105, de 24 de março de 2005, Lei de Biossegurança, que apresenta a seguinte redação:

Art. $5^{\circ}$ É permitida, para fins de pesquisa e terapia, a utilização de células-tronco embrionárias obtidas de embriões humanos produzidos

\footnotetext{
93 Memorial elaborado por Debora Diniz. O estudo "Pesquisa com células-tronco embrionárias: 25 países" foi financiado pelo Ministério da Saúde. Participaram da equipe de pesquisadores: Daniel Avelino, Flávia Squinca, Judith Karine e Kátia Soares Braga. A pesquisa foi realizada por meio de análise direta dos documentos oficiais dos países, no idioma original, nos meses de abril e maio de 2008. A equipe agradece a Antônio Carlos Campos de Carvalho (Brasil), Janaína Penalva (Brasil), Janaína Penalva (Brasil), Mayana Zatz (Brasil), Wederson Santos (Brasil), Ana Cristina Gonzalez Vélez (Colômbia), Anton Van Nierker (África do Sul), Asuncíon Alvaréz (México), Chanda Chakaraborti (Índia), Dafna Feinholz (México), Farzaneh Zahedi (Irã), Florencia Luna (Argentina), Hu Linying (China), Ian Kerridge (Austrália), Isabela Høgne (Dinamarca), Jin-Bao Nie (China), Juan-Guillermo Figueroa (México), Knut Ruyter (Noruega), Maria do Céu Patrão Neves (Portugal), Maria Casado Gonzalez (Espanha), Matti Häyry (Finlândia), Nikola Biller-Adorno (Suíça), Reidar Lie (Noruega), Santosh Chaturvedi (Índia), Stefan Kraus (Noruega), Thomas Podge (Estados Unidos), Trygve Ottersen (Noruega) e Udo Schüklenk (África do Sul). O mapa comparativo foi idealizado pela Agência Neurônio
} 
por fertilização in vitro e não utilizados no respectivo procedimento,

atendidas as seguintes condições:

I- sejam embriões inviáveis;

II - sejam embriões congelados há 3 (três) anos ou mais, na data da publicação desta Lei, ou que, já congelados na data de publicação desta Lei, depois de completarem 3 (três) anos, contados a partir da data de congelamento;

$\S 1^{\circ}$ Em qualquer caso, é necessário o consentimento dos genitores.

$\S 2^{\circ}$ Instituições de pesquisa e serviços de saúde que realizem pesquisa ou terapia com células-tronco embrionárias humanas deverão submeter seus projetos à apreciação e aprovação dos respectivos comitês de ética em pesquisa.

$\S 3^{\circ}$ É vedada a comercialização do material biológico a que se refere este artigo e sua prática implica o crime tipificado no art. 15 da Lei n. 9.434, de 4 de fevereiro de 1997.

2. A tese central da ADIn é a de que "a vida humana acontece na, e a partir da,fecundação" (p. 2). Ao se considerar que a vida humana tem início na fecundação, entende-se que ações que impeçam o desenvolvimento celular para a formação de um feto deveriam ser interpretadas como um atentado à vida e à dignidade da pessoa humana. Assumir a validade do pressuposto resultaria na inconstitucionalidade da pesquisa com células-tronco embrionárias, pois ela detém a divisão celular e impede o desenvolvimento embrionário. Essa foi a interpretação da ADIn para propor a interrupção da pesquisa com células-tronco embrionárias no Brasil.

3. Embriões inviáveis, segundo o Decreto n. 5.591, de 22 de novembro de 2005,

art. $3^{\circ}$, XIII, são "aqueles com alterações genéticas comprovadas por diagnóstico pré-implantacional, conforme normas especificas estabelecidas pelo Ministério da Saúde, que tiveram seu desenvolvimento interrompido por ausência espontânea de clivagem após periodo superior a vinte $e$ quatro horas a partir da fertilização in vitro, ou com alterações morfológicas que comprometam o pleno desenvolvimento do embrião". ${ }^{94}$ Ou seja, trata-se de embriões que não serão utilizados para fins reprodutivos após os procedimentos diagnósticos.

4. O julgamento da constitucionalidade da Lei n. 11.105 prescinde de um pronunciamento definitivo sobre o estatuto do embrião com potencialidade de vida no ordenamento jurídico brasileiro. A pesquisa com células-tronco

${ }^{94}$ REPÚBLICA FEDERATIVA DO BRASIL. Presidência da República. Decreto $\mathrm{n}^{\circ}$ 5.591, de 22 de novembro de 2005. Regulamenta dispositivos da Lei $\mathrm{n}^{\circ} 11.105$, de 24 de março de 2005, que regulamenta os incisos II, IV e V do $\S 1^{\circ}$ do art. 225 da Constituição Federal, e dá outras providências. Diário Oficial [da] República Federativa do Brasil, Brasília, DF, 23 nov. 2005. Disponível em: $<$ http://www.planalto.gov.br/ccivil_03/_Ato2004-2006/2005/Decreto /D5591. htm>. Acesso em: 24 maio 2008. 
será majoritariamente realizada com embriões inviáveis e, apenas por um curto período, com os embriões congelados remanescentes nas clínicas de reprodução assistida. $\mathrm{O}$ fato de a pesquisa brasileira ser preferencialmente conduzida com embriões inviáveis faz com que a pergunta da ADIn sobre o início da vida humana se constitua em um falso problema científico e filosófico.

5. Uma análise comparativa da legislação e regulação internacional de 25 (vinte e cinco) países mostra que a tendência internacional é a de reconhecer a legitimidade ética da pesquisa científica com célulastronco embrionárias. ${ }^{95}$ Além disso, não há registro de nenhum país que tenha enfrentado a constitucionalidade da pesquisa com embriões sob a perspectiva da metafísica do início da vida humana, tal como proposto pela ADIn. Quase todos os países que regulamentaram a pesquisa com célulastronco embrionárias se viram primeiro diante do desafio de como restringir a prática científica, e a maioria optou por reconhecer a liberdade científica como um valor soberano. A história do pensamento científico está repleta de casos de

luta pela garantia da liberdade de pesquisa. Em geral, a tensão entre a censura e a liberdade se deu em torno de questões religiosas, um fato explicado pela própria gênese da universidade medieval, intrinsecamente dependente da Igreja Católica. ${ }^{96}$

6. A tendência internacional de autorizar a pesquisa com células-tronco embrionárias deve ser entendida não apenas como uma aposta dos Estados democráticos no progresso da ciência, mas principalmente como uma afirmação ética da soberania do princípio da liberdade de pesquisa para a promoção do conhecimento como um bem público. ${ }^{97}$ Há uma expectativa de potencialidade terapêutica na pesquisa com células-tronco embrionárias para o tratamento e cura de doenças ainda hoje sem qualquer possibilidade de assistência médica.

\section{Parte II}

\section{Quadro Comparativo Internacional}

\footnotetext{
${ }^{95} \mathrm{O}$ estudo "Pesquisa com células-tronco embrionárias: 25 países" recuperou as leis e normas dos seguintes países: Canadá, Comunidade da Austrália, Confederação Suíça, Coréia, Estado de Israel, Estados Unidos da América, Estados Unidos Mexicanos, Federação Russa, Japão, Reino da Dinamarca, Reino da Espanha, Reino da Noruega, Reino da Suécia, Reino dos Países Baixos, Reino Unido da Grã-Bretanha e Irlanda do Norte, República da África do Sul, República da Finlândia, República da França, República da Índia, República de Cingapura, República de Portugal, República Federal da Alemanha, República Islâmica do Irã, República Italiana e República Popular da China.

${ }^{96}$ PENA-RUIZ, Henri. Histoire de la laïcité. Paris: Découvertes Gallimard, 2005. 144 p. (Histoire); RENAUT, Alain; TOURAINE, Alain. Un débat sur la laïcité. Paris: Stock, 2005. 172 p. (Les Essais).

${ }^{97}$ DINIZ, Debora. Em Benefício da Coletividade - Células-Tronco. O Estado de S. Paulo,

São Paulo, 14 out. 2007. Caderno Aliás, p. 3.
} 
1. O estudo "Pesquisa com células-tronco embrionárias: 25 países" mostra que a tendência legislativa internacional em países com capacidade efetiva de promover investigações médicas é a de autorizar a pesquisa com célulastronco embrionárias (vide mapa em anexo). Essa pesquisa é permitida em 23 (vinte e três) países por marco legal ou normas éticas, e apenas 1 (um) país limita a pesquisa a linhagens embrionárias importadas. A República Italiana é o único país com capacidade tecnológica equivalente à brasileira que proíbe por lei a pesquisa com células-tronco embrionárias.

2. A maioria dos 25 (vinte e cinco) países que compõem a amostra desse estudo é de nações democráticas e laicas, com desenvolvimento científico, médico e tecnológico equivalente ou superior ao brasileiro. Juntos, eles detêm mais da metade da população mundial. São responsáveis pela maior parte das publicações em saúde nos principais periódicos científicos e pelos mais importantes registros de patentes internacionais. Esses países representam cinco regiões do globo e acolhem expressivas comunidades filosóficas, tais como as seguidoras de religiões budistas, cristãs, hinduístas, islâmicas e judaicas. Os poucos países organizados por confissões religiosas, como o Estado de Israel, autorizam a pesquisa com célulastronco embrionárias em um amplo leque de possibilidades. ${ }^{98} \mathrm{O}$ caso da República Islâmica do Irã é outro que merece destaque, pois pesquisas com células-tronco embrionárias vêm sendo conduzidas a partir de fatwas (posicionamentos religiosos que autorizam ou não uma ação) favoráveis. A abertura do debate iraniano se deu com a mudança da lei de aborto, em 2003. ${ }^{99}$

3. Entre os 25 (vinte e cinco) países, a Itália é o único com capacidade tecnológica e estrutura científica compatível com a brasileira que criminaliza a pesquisa com células-tronco embrionárias. Sua legislação, datada de 2004, é sobre reprodução assistida e foi regulada por decreto do Ministério da Saúde em abril de 2008. ${ }^{100} \mathrm{O}$ cerne da lei italiana é controlar

${ }^{98}$ ESTADO DE ISRAEL.

—_ celular genética) (alterações), 2004]. , n. 1934, p. 339-346, 31 mar. 2004.

Disponível em:

$<$ http://www.knesset.gov.i1/laws/heb/FileD.asp?Type=1\&LawNum=1934\&SubNum=1>. Acesso em: 24 maio 2008.

99 REPÚBLICA ISLÂMIC̄A DO IRÃ. ! "\#_\$ \&_ \&' ( $)$ \#*+\$

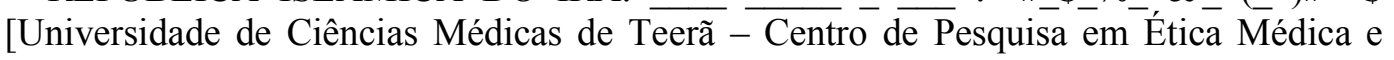
História da Medicina].

[Diretrizes éticas referentes ao

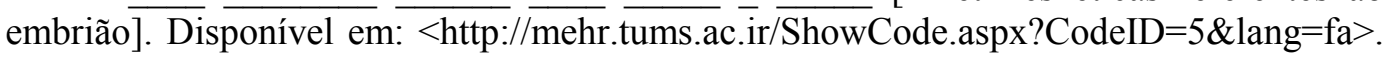
Acesso em: 24 maio

2008; REPÚBLICA ISLÂMICA DO IRÃ. Iran Parliament. Therapeutic Abortion Act [Lei do Aborto Terapêutico]. Ref\#2/85876, 2005 June 21; LARIJANI, Bagher; ZAHEDI, Farzaneh. Health promotion, Islamic ethics and Law in Iran. Daru Suppl, n. 1, p. 7-9, Jan. 2006.

${ }^{100}$ REPÚBLICA ITALIANA. Legge 19 febbraio 2004, n. 40. Norme in materia di procreazione medicalmente assistita [Normas sobre Procriação Medicamente Assistida]. 
o acesso às tecnologias reprodutivas, impedindo novas formas de constituição de família, ao inaugurar no ordenamento jurídico o reconhecimento legal e simbólico ao embrião extracorpóreo. ${ }^{101} \mathrm{O}$ debate nesse país foi moralmente intenso, e há argumentos propostos pela ADIn que se assemelham à lei italiana - em particular, a proposição de que a pesquisa com células-tronco adultas deva ser incentivada em detrimento daquela com células-tronco embrionárias. Uma possível explicação para a singularidade da lei italiana no cenário internacional é a participação da Igreja Católica nas decisões do Estado, cujos cientistas sofreram ameaças de excomunhão devido à defesa da pesquisa com embriões. ${ }^{102}$

4. Israel é um contraponto interessante à posição italiana. Diferentemente da Itália ou do Brasil, Israel não é um país laico. Isso significa que suas decisões políticas são oficialmente fundamentadas em valores religiosos. Foi nesse encontro entre ciência, bioética e religião que o tema da pesquisa com células-tronco embrionárias esteve na pauta de discussões legais do país há quase uma década. Após um pedido de moratória às pesquisas com embriões humanos em 1999, o Comitê Consultivo de Bioética propôs a abertura das pesquisas em 2001, amparado em dois argumentos centrais à tradição judaica: 1. o status moral de um embrião congelado é comparável ao de gametas, portanto, não há qualquer ameaça à dignidade humana em sua manipulação para fins científicos; e 2. vê-se grande valor nas tentativas científicas de cura e tratamento para doenças, por isso a posição marcadamente favorável às pesquisas genéticas no país, inclusive a clonagem terapêutica. ${ }^{103}$

Gazzetta Ufficiale, n. 45, 24 febbr. 2004. Disponível em: $<$ http://www.parlamento.it/parlam/leggi/040401.htm>. Acesso em: 24 maio 2008; REPÚBLICA ITALIANA. Ministero della Salute. Decreto 11 aprile 2008. Linee guida in materia di procreazione medicalmente assistita [Linhas Gerais Sobre Procriação Medicamente Asistida]. Gazzetta Ufficiale, n. 101, 30 apr. 2008. Disponível em: $<\mathrm{http}: / \mathrm{www}$.gazzettaufficiale.it $/$ guridb/dispatcher? service $=\quad 1 \&$ datagu $\quad=2008-04-$ $30 \&$ task $=$ dettaglio\&numgu $=101 \&$ redaz $=08$ A02587\& tmstp $=1209886579700>$. Acesso em: 24 maio 2008.

${ }^{101}$ HANAFIN, Patrick. Gender, citizenship and human reproduction in contemporary Italy. Feminist Legal Studies, v. 14, n. 3, p. 329-452, 2006.

10 PASSOTI, Jacopo; STAFFORD, Ned. It's legal: Italian researchers defend their work with

embryonic stem cells. Nature, v. 442, n. 7100, p.229, 2006 July 20.

${ }^{102}$ PASSOTI, Jacopo; STAFFORD, Ned. It's legal: Italian researchers defend their work with

embryonic stem cells. Nature, v. 442, n. 7100, p.229, 2006 July 20.

${ }^{103}$ GROSS, Michael L.; RAVITSKY, Vardit. Israel: bioethics in a Jewish-democratic state.

Cambridge Quarterly of Healthcare Ethics, v. 12, n. 3, p. 247-255, July 2003;

PRAINSACK, Barbara. 'Negotiating life': the regulation of human cloning and embryonic

stem cell research in Israel. Social Studies of Science, v. 36, n. 2, p. 173-205, April 2006. 
5. As primeiras regulamentações internacionais datam dos anos 1990, período de difusão das tecnologias reprodutivas para solucionar questões de fertilidade e das pesquisas médicas com células-tronco. $\mathrm{O}$ caso do Reino Unido da Grã-Bretanha e Irlanda do Norte é paradigmático, pois apresenta um fenômeno que se reproduziu na última década em diferentes países: a regulamentação da pesquisa com células-tronco embrionárias foi deflagrada por uma ampla discussão bioética sobre as tecnologias reprodutivas. $\mathrm{O}$ Relatório Warnock foi uma peça de debate ético de vanguarda sobre tecnologias reprodutivas, em que se propôs o conceito de pré-embrião para representar o conjunto de células humanas com até 14 dias de desenvolvimento. ${ }^{104}$ Como resultado de quase uma década de discussão, o Reino Unido foi o primeiro país a autorizar em lei a pesquisa com célulastronco embrionárias e clonagem terapêutica, em 2001. ${ }^{105}$

6. A Lei n. 11.105 menciona embriões congelados e embriões inviáveis, apesar de a Resolução n. 33 da Diretoria Colegiada da Anvisa, de 17 de fevereiro de 2006, utilizar o termo "pré-embrião", tal como proposto pelo Relatório Warnock: "produto da fusão de células germinativas até 14 dias após a fertilização, in vivo ou in vitro, quando do início da formação da estrutura que dará origem ao sistema nervoso". ${ }^{106}$ Nesse sentido, o marco legal e regulatório brasileiro adota uma dupla terminologia para representar as células humanas com até 14 dias de fecundação, isto é, "embrião" e "préembrião", o que em certa medida reproduz a diversidade conceitual do debate internacional. ${ }^{107}$

\footnotetext{
${ }^{104}$ WARNOCK, Mary. Report of the Committee of Inquiry into Human Fertilisation and

Embriology. London: Department of Health and Social Security, July 1984.

${ }^{105}$ DECKERS, Jan. Why current UK legislation on embryo research is immoral: how the argument from lack of qualities and the argument from potentiality have been applied and why they should be rejected. Bioethics, v. 19, n. 3, p. 252-171, 2005.

106 REPÚBLICA FEDERATIVA DO BRASIL. Agência Nacional de Vigilância Sanitária.

Diretoria Colegiada. Resolução no 33, de 17 de fevereiro de 2006. Aprova o regulamento técnico para o funcionamento dos bancos de células e tecidos germinativos. Diário Oficial

[da] República Federativa do Brasil, Brasília, DF, 20 fev. 2006. Disponível em: $<$ http://elegis.

anvisa.gov.br/leisref/public/showAct.php?id=20954\&word=\#'>. Acesso em: 24 maio 2008.
}

107 REPÚBLICA FEDERATIVA DO BRASIL. Agência Nacional de Vigilância Sanitária.

Diretoria Colegiada. Resolução $\mathrm{n}^{\circ} 29$, de 12 de maio de 2008. Aprova o regulamento técnico

para o cadastramento nacional dos bancos de células e tecidos germinativos (BCTG) e o envio

da informação de produção de embriões humanos produzidos por fertilização in vitro e não

utilizados no respectivo procedimento. Diário Oficial [da] República Federativa do Brasil,

Brasília, DF, 13 maio 2008. Disponível em: <http://elegis. 
7. Muitos países autorizam apenas a pesquisa com embriões congelados remanescentes de clínicas de reprodução assistida, tal como proposto pela lei brasileira. Embriões remanescentes são aqueles excedentes de um projeto reprodutivo de um casal que, com restrições de fertilidade, tenha buscado a medicina para ter filhos biologicamente vinculados. Regra geral, após a concretização do projeto reprodutivo, os casais preferem doar os embriões congelados para a pesquisa científica a descartá-los. ${ }^{108}$ Essa é a situação legislativa do Brasil, da República Francesa e do Reino dos Países Baixos, por exemplo. ${ }^{109} \mathrm{O}$ Reino da Noruega autoriza a pesquisa com embriões remanescentes em clínicas de reprodução assistida, mas foi o único país nórdico a proibi-la durante um período. Em janeiro de 2008, a lei norueguesa foi revista. ${ }^{110}$ Há outros países, no entanto, que, além de

anvisa.gov.br/leisref/public/showAct.php?id=31098\&word=>. Acesso em: 24 maio 2008.

${ }^{108}$ BURTON, Peter; SANDERS, Katherine. Patient attitudes to donation of embryos for research in Western Australia. The Medical Journal of Australia, v. 180, n. 11, p. 559561 ,

2004 June 7; BUJURESTEN, Kerstin; HOVATTA, Outi. Donation of embryos for stem cell

research: how many couples consent? Human Reproduction, v. 18, n. 6, p. 1353-1355, 2003; TARUN, Jain; STACEY, A. Missmer. Support for embryonic stem cell research among

infertility patients. Fertility and Sterility, 2008. In press; HUG, Kristina. Motivation to donate or not donate surplus embryos for stem-cell research: literature review. Fertility and

Sterility, v. 89, n. 9, p. 263-277, 2008.

${ }^{109}$ REPÚBLICA FEDERATIVA DO BRASIL. Lei no 11.105 , de 24 de março de 2005.

Regulamenta os incisos II, IV e V do $\S 1^{\circ}$ do art. 225 da Constituição Federal [...] e dá outras

providências. Diário Oficial [da] República Federativa do Brasil, Brasília, DF, 28 mar. 2005. Disponível em: $<$ http://www.planalto.gov.br/ccivil_03/_Ato2004-

2006/2005/Lei/L11105.htm>. Acesso em: 24 maio 2008; RËPÚBLICA DA FRANÇA. Loi $\mathrm{n}^{\mathrm{O}}$

2004-800 du 6 août 2004 relative à la bioéthique [Lei $\mathrm{n}^{\circ}$ 2004-800, de 6 de agosto de 2004 , relativa à bioética]. Journal Officiel de la République Française, Paris, texte 1 sur 92, 7 août. 2004. Disponível em: $<\mathrm{http}: / /$ www.agence-biomedecine.fr/fr/doc/revision

loi060804.pdf>. Acesso em: 24 maio 2008; REINO DOS PAÍSES BAIX̄OS. Act Containing Rules Relating to the Use of Gametes and Embryos (Embryos Act) [Lei contendo regras

relativas ao uso de gametas e embriões (Lei dos Embriões)]. $1^{\circ}$ set. 2002. Tradução oficial

para o inglês do texto publicado no Bulletin of Acts and Decrees [Staatsblad]. Disponível em:

$<$ http://www.minvws.nl/includes/dl /openbestand.asp?File=/images/eng-embryowettekst_ tcm

20-107819.pdf>. Acesso em: 24 maio 2008.

${ }^{110}$ REINO DA NORUEGA. Lov om humanmedisinsk bruk av bioteknologi mm

(bioteknologiloven) [Lei sobre a medicina humana e a biotecnologia]. Lov-2003-12-05100. 
permitir a pesquisa com os embriões excedentes das clínicas de reprodução assistida, autorizam a produção de embriões para fins exclusivos de investigação científica, como é o caso da Comunidade da Austrália, Japão, República da África do Sul, República de Cingapura, República Popular da China e Reino da Suécia. ${ }^{111}$

Disponível em: $<$ http://www.lovdata.no/all/nl-20031205-100.html>. Acesso em: 24 maio 2008.

${ }^{111}$ COMUNIDADE DA AUSTRÁLIA. Prohibition of Human Cloning for Reproduction Act

2002. Act $n^{\circ} 144$ of 2002 as amended [Lei de Proibição de Clonagem Humana para

Reprodução 2002. Lei $n^{\circ}$ 144, de 2002, com emendas]. Compilation (current), Office of Legislative Drafting and Publishing, Attorney-General's Department, Canberra, 2007 June 12.

Disponível em:

$<$ http://www.comlaw.gov.au/ComLaw/Legislation/ActCompilation1.nsf/0/647EBC139F

B39F

DDCA2572F7007B272E/\$file/ProhibHumanCloningforRep2002_WD02.pdf>. Acesso em:

24 maio 2008; COMUNIDADE DA AUSTRÁLIA. Research Involving Human Embryos Act

2002. Act $n^{\circ} 145$ of 2002 as amended [Lei da Pesquisa Envolvendo Embriões Humanos 2002.

Lei $\mathrm{n}^{\mathrm{o}}$ 145, de 2002, com emendas]. Compilation (current), Office of Legislative Drafting

and Publishing, Attorney-General's Department, Canberra, 2007 June 12. Disponível em: $<$ http://www.comlaw.gov.au/ComLaw/Legislation/ActCompilation1.nsf/0/03F95E485D0 423

1DCA2572F80003B1C3/\$file/ResearchInvolvingHumanEmbryosAct2002_WD02.pdf $>$.

Acesso em: 24 maio 2008; JAPÃO. Act on Regulation of Human Cloning Techniques. Act

$n^{0} 146$ of 2000 [Lei sobre a Regulação da Clonagem Humana. Lei no 146, de 2000]. 2001, June 6. Tradução para o inglês pelo [Secretariado do Gabinete]. Disponível em:

$<$ http://www.cas.go.jp/jp/seisaku/hourei/data/htc.pdf>. Acesso em: 24 maio 2008;

REPÚBLICA DA ÁFRICA DO SUL. National Health Act. Act n 61 of 2003 [Lei Nacional

de Saúde. Lei $\mathrm{n}^{\circ}$ 61, de 2003].. Government Gazette, Cape Town, v. 469, n. 26595, 2004

July 23. Disponível em: <http://www.info.gov.za/view/DownloadFileAction?id=68039>. Acesso em: 24 maio 2008; REPÚBLICA DE CINGAPURA. Human Cloning and Other Prohibited Practices Act. Act $n^{\circ} 35$ of 2004 [Lei da Clonagem Humana e de Outras Práticas

Proibidas. Lei $\mathrm{n}^{\mathrm{o}} 35$, de 2004]. $1^{\mathrm{o}}$ out. 2004. Singapore Statutes, Attorney-General's

Chamber \& Managing for Excellence Office, revised edition, Chapter 131B, 2005. Disponível

em: $\quad<$ http://statutes.agc.gov.sg/non_version/cgi-bin/cgi_retrieve.pl?actno=REVED-

131B\&

doctitle=HUMAN\%20CLONING\%20AND\%20OTHER\%20PROHIBITED\%20PRACTI $\mathrm{CE}$

S\%20ACT\%0a\&date=latest\&method=part\&sl=1>. Acesso em: 24 maio 2008; REPÚBLICA

POPULAR DA CHINA. [Diretrizes éticas para a pesquisa com células embrionárias humanas]. Ministério da Ciência e Tecnologia e Ministério da 
8. Alguns países autorizam a pesquisa com células-tronco embrionárias por marco legal, semelhantemente ao Brasil, como é o caso do Reino da Dinamarca, Reino da Espanha, República da Finlândia, França, Reino Unido e Suécia. ${ }^{12}$ Outros países permitem que a pesquisa seja conduzida

Saúde, 24 dez. 2003. Disponível em: <http://www.most.gov.cn/zfwj/zfwj2003/200512/ t20051214_54948.htm>. Acesso em: 24 maio 2008; REINO DA SUÉCIA. Lag (1991:115)

om åtgärder i forsknings- eller behandlingssyfte med ägg från människa [Lei no 115 , de

1991, concernente a medidas acerca de pesquisa ou tratamento com óvulos humanos]. 14 mar.

${ }^{112}$ REINO DA DINAMARCA. Lov om kunstig befrugtning i forbindelse med lægelig behandling, diagnostik og forskning $\mathbf{m} . v$. [Lei sobre inseminação artificial referente a tratamento, diagnóstico e pesquisa médica]. Lov nr 460 af 10 juni 1997. Disponível em: $<$ https://www.retsinformation.dk/Forms/R0710.aspx?id=84963>. Acesso em: 24 maio 2008.

REINO DA DINAMARCA. Lov om ændring af lov om kunstig befrugtning i forbindelse

med lægelig behandling, diagnostik og forskning m.v. (Forskning på embryonale stamceller) [Lei alterando a lei sobre inseminação artificial referente a tratamento, diagnóstico e pesquisa médica (pesquisa em células-tronco embrionárias)]. Lov nr 427 af 10

juni 2003, L 209. Disponível em: <https://www.retsinformation.dk/Forms/R0710. aspx?id=9734>.Acesso em: 24 maio 2008. REINO DA ESPANHA. Ley 35/1988, de 22 de

noviembre, sobre técnicas de reproducción asistida [Lei ${ }^{\circ} 35$, de 22 de novembro de 1988 ,

sobre técnicas de reprodução assistida]. Boletín Oficial del Estado, Madrid, n. 282, 24 nov.

1988. Disponível em: <http://www.congreso.es/constitucion/ficheros/leyes_espa/1_035 1988.pdf>. Acesso em: 24 maio 2008; REINO DA ESPANHA. Ley 14/2007, de 3 de julio, de

investigación biomédica [Lei n ${ }^{\circ} 14$, de 3 de julho de 2007, de investigação biomédica].

Boletín Oficial del Estado, Madrid, n. 159, 4 jul. 2007. Disponível em:

$<$ http://www.congreso.es/constitucion/ficheros/leyes_espa/1_014_2007.pdf $>$. Acesso em: 24

maio 2008. REPÚBLICA DA FINLÂNDIA. Laki lääketieteellisestä tutkimuksesta.

Laki

488/1999 [Lei da pesquisa médica. Lei 488/1999]. 9 abr. 1999. Disponível em:

$<$ http://www.finlex.fi/fi/laki/alkup/ 1999/19990488>. Acesso em: 24 maio 2008;

REPÚBLICA DA FRANÇA. Loi no 2004-800 du 6 août 2004 relative à la bioéthique

[Lei $\mathrm{n}^{\mathrm{O}}$

2004-800, de 6 de agosto de 2004, relativa à bioética]. Journal Officiel de la

République

Française, Paris, texte 1 sur 92, 7 août 2004. Disponível em:

$<$ http://www.agencebiomedecine.

fr/fr/doc/revision_loi060804.pdf > . Acesso em: 24 maio 2008; REINO UNIDO

DA GRÃ-BRETĀNHA E IRLANDA DO NORTE. Human Fertilisation and

Embryology

Act 1990 [Lei da Fertilização Humana e Embriologia 1990]. The UK Statute Law

Database,

Ministry of Justice, c. 37, 1990 Nov. 1. Disponível em: <http://www.statutelaw. 
sem que tenha havido um debate legislativo conclusivo, como ocorreu na República Portuguesa, República da Índia e China, havendo um reconhecimento dos pareceres da Comissão Nacional Consultiva de Bioética ou do Ministério da Saúde de cada país. ${ }^{113}$ Há, ainda, os países que autorizam a pesquisa com linhagens embrionárias existentes e embriões já congelados, enquanto o debate legislativo se desenvolve localmente, como é o caso do Irã.

9. Os Estados Unidos da América são um país de referência para o debate internacional em bioética, muito embora seu marco legal se restrinja às questões relacionadas ao financiamento dos estudos. A pesquisa com

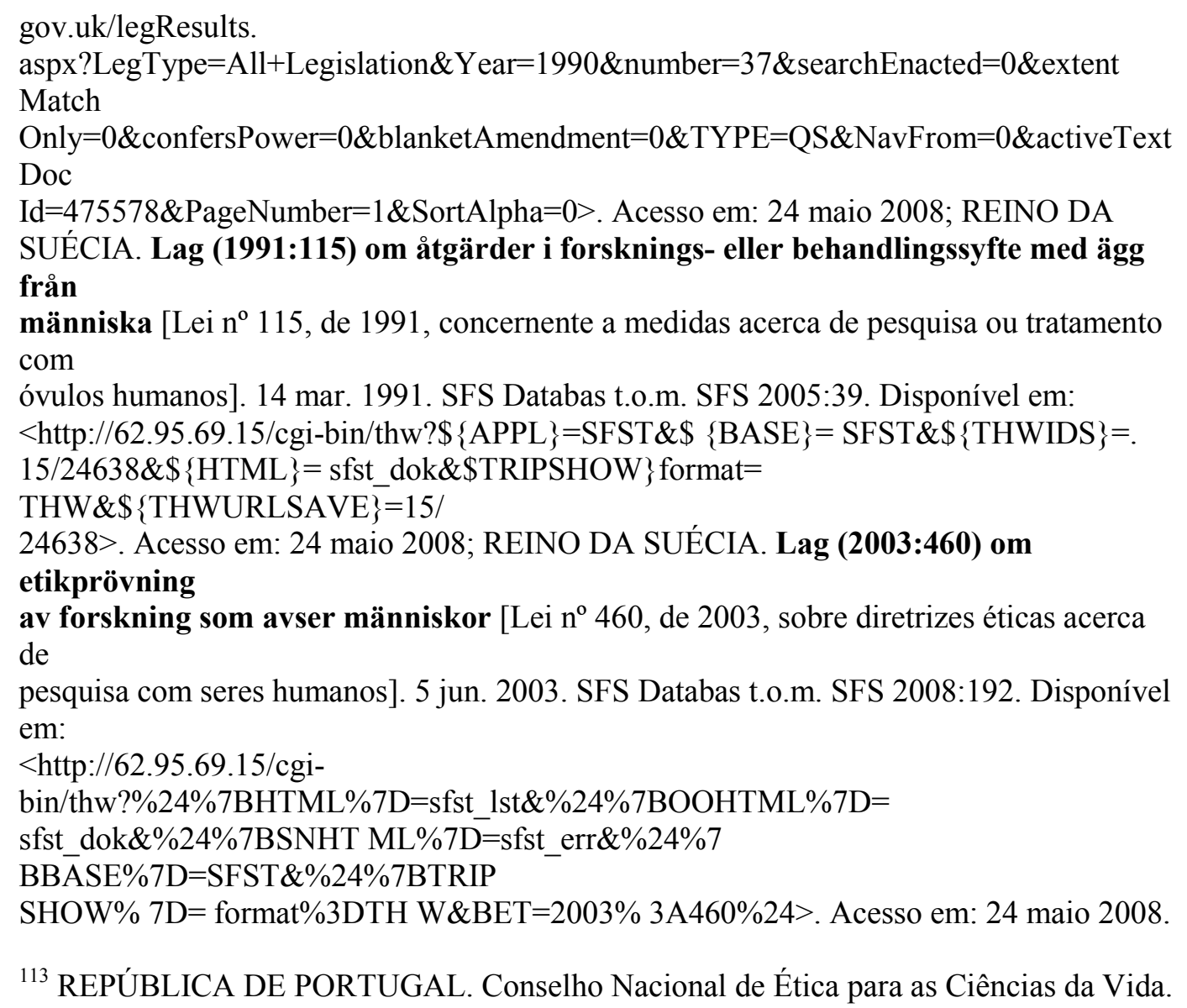
Parecer sobre a investigação em células estaminais. Parecer $\mathrm{n}^{\circ} 47$, de 11 de novembro de

2005. Disponível em: <http://www.cnecv.gov.pt/NR/rdonlyres/FA945223-C04B4B5DA48C-

E9F1864651D1/0/P047 ParecerCE.pdf $>$. Acesso em: 24 maio 2008; REPÚBLICA POPULAR DA CHINA. [Diretrizes éticas para a pesquisa com células embrionárias humanas]. Ministério da Ciência e Tecnologia e Ministério da Saúde, 24 dez. 2003. Disponível em:

$<$ http://www.most.gov.cn/zfwj/zfwj2003/200512/t20051214_54948.htm>. Acesso em: 24 maio 2008; REPÚBLICA DA ÍNDIA. Department of Biotechnology. Indian Council of Medical Research. Guidelines for stem cell research and therapy. Nova Deli: Indian Council of Medical Research, 2007. Disponível em: $<\mathrm{http} / / / \mathrm{www}$. icmr.nic.in/stem_cell/stem_cell_guidelines.pdf $>$. Acesso em: 24 maio 2008. 
célulastronco embrionárias é autorizada nos Estados Unidos, desde que não conte com financiamento federal. Uma lei de 2001 permite a pesquisa financiada por recursos federais com linhagens de células-tronco já existentes. Alguns estados, como Califórnia, Conecticute, Illinois e Maryland, editaram leis que autorizam o financiamento estadual para a pesquisa com células-tronco embrionárias. ${ }^{114}$ Mesmo com essas restrições de financiamento público, artigos de revisão internacional indicam que os Estados Unidos são o país que mais publica resultados de pesquisa experimental com linhagens de células-tronco embrionárias, seguido por Israel, Reino Unido e Coréia. ${ }^{115}$

10. A República Federal da Alemanha é outro país com regulamentações singulares. $^{116}$ A pesquisa com células-tronco embrionárias foi regulamentada por lei em 2002, a qual proibiu o uso de embriões alemães,

${ }^{114}$ ESTADOS UNIDOS DA AMÉRICA. California (state). State Constitution. Art. XXXV.

Disponível em: <http://www.leginfo.ca.gov/const-toc.html>. Acesso em: 24 maio 2008; ESTADOS UNIDOS DA AMÉRICA. Connecticut (state). Public Act no 05-149. An act permitting stem cell research and banning the cloning of human beings [Lei permitindo a pesquisa com células-tronco e proibindo a clonagem de seres humanos]. 15 jun. 2005.

Disponível em: < http://www.cga.ct.gov/2005/act/Pa/ 2005PA-00149-r00sb-00934pa.htm>.

Acesso em: 24 maio 2008; ESTADOS UNIDOS DA AMÉRICA. Illinois (state).

\section{Executive}

Order creating the Illinois Regenerative Institute for stem cell research, n. 6-2005

[Ordem Executiva $n^{\circ}$ 6, de 2005, criando o Instituto Regenerativo de Illinois para a pesquisa

com células-tronco]. Executive Department, Springfield, IL. 2005 July 12. Disponível em:

$<$ http://www.illinois.gov/ Gov/pdfdocs/execorder2005-6.pdf>. Acesso em: 24 maio 2008; ESTADOS UNIDOS DA AMÉRICA. Maryland (state). Maryland Code. Article 83A.

Title 5:

Maryland Stem Cell Research Program[Título 5: Programa de Pesquisa com CélulasTronco de Maryland]. Disponível em: <http://www.michie.com/maryland/lpext.dll?f= templates\&fn= main-h.htm\&2.0>. Acesso em: 24 maio 2008; ESTADOS UNIDOS DA AMÉRICA. Maryland (state). Maryland Stem Cell Research Act of 2006. Senate Bill 144

[Lei da Pesquisa com Células-Tronco de Maryland de 2006. Projeto de Lei ${ }^{\circ} 144$ do Senado].

Disponível em: $<$ http://www.michie.com/maryland/lpext.dll?f= templates\&fn=mainh. htm\&2.0 >. Acesso em: 24 maio 2008.

${ }^{115}$ GUHR, Anke; KURTZ, Andreas; FRIEDGEN, Kelley; LÖSER, Peter. Current state of human embryonic stem cell research: an overview of cell lines and their use in experimental

work. Stem Cells, v. 24, n. 10, p. 2187-2191, Oct. 2006.

${ }^{116}$ HEINEMANN, Thomas; HONNEFELDER, Ludger. Principles of ethical decision making

regarding embryonic stem cells in Germany. Bioethics, London v. 16, n. 6, p. 530-542, 2002. 
permitindo que fossem utilizadas linhagens já importadas de células-tronco embrionárias, produzidas em outros países até janeiro daquele ano. ${ }^{117} \mathrm{Em}$ fevereiro de 2008, após intensa negociação com as comunidades científicas alemãs, o prazo de aproveitamento das linhagens foi ampliado para maio de $2007 .{ }^{118}$ Formalmente, portanto, a Alemanha proíbe a produção de célulastronco embrionárias, mas autoriza a pesquisa com material biológico importado, ou seja, com células humanas não-alemãs. Essa combinação entre um marco legal restritivo quanto ao uso de células-tronco embrionárias de origem alemã e a possibilidade de importação de linhagens foi alvo de várias discussões internacionais no campo da bioética. ${ }^{119}$ Há um consenso de que a história do nazismo dificulta o debate democrático e razoável na Alemanha, por isso a proibição de uso de material biológico nativo; porém, também se concorda que a legitimidade do princípio da liberdade de pesquisa é o que permitiu a garantia do direito à investigação científica com linhagens importadas.

11. Uma particularidade da Lei n. 11.105 foi determinar que a pesquisa científica será preferencialmente conduzida com embriões inviáveis. Nenhum dos 25 (vinte e cinco) países analisados estabelece a diferenciação legal entre embriões congelados viáveis e inviáveis para a pesquisa científica. A tendência internacional é demarcar a distinção entre embriões congelados

remanescentes de projetos reprodutivos e embriões produzidos para fins exclusivos de pesquisa científica, havendo uma maior harmonia da legislação internacional em reconhecer como legítima a investigação com

\footnotetext{
${ }^{117}$ REPÚBLICA FEDERAL DA ALEMANHA. Gesetzes zur Sicherstellung des Embryonenschutzes im Zusammenhang mit Einfuhr und Verwendung menschlicher embryonaler Stammzellen (Stammzellgesetz - StZG) [Lei para a garantia de proteção de

embriões em relação a importação e uso de células-tronco embrionárias humanas]. 27 fev. 2002. BGBl. I S. 2277, Drucksache 14/8394, Deutscher Bundestag, 14. Wahlperiode. Disponível em: < $<$ ttp://dip.bundestag.de/btd/14/083/1408394.pdf > Acesso em: 24 maio 2008.
}

${ }^{118}$ REPÚBLICA FEDERAL DA ALEMANHA. Gesetzes zur Änderung des

Stammzellgesetzes [Lei para a alteração da lei de células-tronco]. 6 fev. 2008.

Drucksache

16/7981, Deutscher Bundestag, 16. Wahlperiode. Disponível em:

$<$ http://www.biotechnologie.de/bio/ generator/Redaktion/PDF/de/2008-entwurf-roespel, property $=$ pdf,bereich $=$, sprache $=$ en, $r w b=$ true.pdf $>$. Acesso em: 24 maio 2008.

${ }^{119}$ HEINEMANN, Thomas; HONNEFELDER, Ludger. Principles of ethical decision making

regarding embryonic stem cell research in Germany. Bioethics, London, v. 16, n. 6, p. $530-$

543, 2002; TAKALA, Tuija; HÄYRY, Matti. Benefiting from past wrongdoing, human embryonic stem cell lines, and the fragility of the German legal position. Bioethics, London,

v. 21 , n. 3 , p. $150-159,2007$. 
embriões congelados, não autorizando sua produção exclusivamente para pesquisa. ${ }^{120}$ Não há, portanto, diferenciação feita pela lei brasileira entre embriões congelados e embriões inviáveis.

12. Essa singularidade da lei brasileira, regulamentada pelo Decreto $\mathrm{n}$. 5.591 de 2005, em que se definiram embriões inviáveis, foi já uma concessão argumentativa à metafísica do início da vida imposta durante a negociação legislativa. Não há como imputar ameaça ao princípio do direito à vida perante um embrião congelado inviável de uma clínica de reprodução assistida. Mesmo que as mulheres sejam forçadas a transferir para o útero os embriões congelados inviáveis, a maioria deles não se transformará em um feto. É nesse sentido que o debate sobre o início da vida se constitui em um falso problema filosófico e científico para o julgamento da constitucionalidade do artigo $5^{\circ}$ da Lei n. 11.105.

13. Portugal apresenta uma situação particular quanto à regulação no contexto da União Européia. Muito embora não possua marco legal específico que regulamente a pesquisa com células-tronco, pareceres do Conselho de Ética vêm assumindo um papel regulador da prática científica no país. O Parecer n. 44, sobre a Procriação Medicamente Assistida, afirma que, se o destino de embriões remanescentes de fertilização in vitro for o descarte, eles poderão ser utilizados para fins científicos. ${ }^{121}$ Ou seja, na prática, a pesquisa com células-tronco embrionárias pode ser realizada em Portugal sob o amparo dos pareceres do Conselho de Ética, cujos fundamentos são bastante próximos do marco legal brasileiro. ${ }^{122}$

14. Um importante consenso ético nas legislações e regulamentações dos 25 (vinte e cinco) países é o reconhecimento de que embriões congelados e

\footnotetext{
${ }^{120}$ Há teóricos da bioética que sustentam que a diferença entre embriões remanescentes de

projetos reprodutivos e embriões produzidos para fins reprodutivos não deve ser significativa

para a avaliação ética de potenciais benefícios proporcionados pelas pesquisas.

DEVOLDER,

Katrien. Human embryonic stem cell research: why the discarded-created distinction cannot

be based on the potentiality argument. Bioethics, v. 19, n. 2, p. 167-186, 2005.

${ }^{121}$ REPÚBLICA DE PORTUGAL. Conselho Nacional de Ética para as Ciências da Vida. Parecer sobre a investigação em células estaminais. Parecer $n^{\circ} 47$, de 11 de novembro de

2005. Disponível em: <http://www.cnecv.gov.pt/NR/rdonlyres/FA945223-C04B4B5DA48C-

E9F1864651D1/0/P047_ParecerCE.pdf>. Acesso em: 24 maio 2008.

${ }^{122}$ REPÚBLICA DE PORTUGAL. Conselho Nacional de Ética para as Ciências da Vida. Parecer sobre a investigação em células estaminais. Parecer $n^{\circ} 47$, de 11 de novembro de

2005. Disponível em: <http://www.cnecv.gov.pt/NR/rdonlyres/FA945223-C04B-

4B5DA48C-

E9F1864651D1/0/P047_ParecerCE.pdf>. Acesso em: 24 maio 2008.
} 
remanescentes em clínicas de reprodução assistida somente podem ser utilizados na pesquisa científica com o consentimento dos genitores, uma garantia ética também presente na lei brasileira. Por uma matriz ética semelhante, grande parte das legislações também proíbe a comercialização de embriões, sendo autorizado apenas o comércio de linhagens de célulastronco embrionárias, como é o caso da Alemanha.

15. Quase todos os países com marco legal sobre o assunto reconhecem a necessidade de que protocolos de pesquisa com células-tronco embrionárias sejam avaliados por comitês de ética antes de sua execução. No caso brasileiro, essa é uma previsão legal que reforça uma estrutura de revisão ética com mais de 10 (dez) anos de existência no país - o Sistema CEP/Conep. ${ }^{123}$ Uma particularidade desse sistema é que ele se encontra diretamente vinculado ao Conselho Nacional de Saúde, importante órgão de definição da política de saúde do país e de participação social. São quase 600 comitês em todas as regiões do Brasil, localizados em universidades, centros de pesquisa e hospitais.

16. A Resolução n. 29, de 12 de maio de 2008, da Diretoria Colegiada da Anvisa, impulsionará o trabalho de revisão ética e monitoramento das pesquisas com células-tronco embrionárias no país, pois instituiu os procedimentos para cadastramento dos bancos de células e tecidos germinativos, além do sistema de informação sobre embriões humanos nas clínicas de reprodução assistida. A regulamentação do Sistema Nacional de Embriões (SisEmbrio) foi um passo importante para o censo de embriões congelados em clínicas de reprodução assistida no país. O único dado disponível atualmente foi produzido pela Sociedade Brasileira de Reprodução Humana Assistida (SBRHA), em amostra composta pelas 15 (quinze) maiores clínicas de reprodução assistida, indicando que há 9.914 embriões congelados no Brasil, sendo 3.219 congelados há mais de três anos. ${ }^{124}$ A criação do SisEmbrio permitirá não apenas o monitoramento das pesquisas com células-tronco embrionárias, mas também a prática da medicina reprodutiva no Brasil.

\footnotetext{
${ }^{123}$ REPÚBLICA FEDERATIVA DO BRASIL. Conselho Nacional de Saúde. Resolução $\mathrm{n}^{\mathrm{o}}$

196, de 10 de outubro de 1996. Aprova as diretrizes e normas regulamentadoras de pesquisa envolvendo seres humanos. Diário Oficial [da] República Federativa do Brasil, Brasília,

DF, n. 201, 16 out. 1996. Disponível em: <http://conselho.saude.gov.br/resolucoes /1996/Reso196.doc>. Acesso em: 24 maio 2008.

${ }^{124}$ REPÚBLICA FEDERATIVA DO BRASIL. Agência Nacional de Vigilância Sanitária.

Memorando $\mathbf{n}^{\circ}$ 077, de 2005 - GGSTO/ANVISA. 2005. Segundo dados da Anvisa, são 104 centros filiados à Sociedade Brasileira de Reprodução Assistida (SBRA), à Sociedade Brasileira de Reprodução Humana (SBRH) ou à Federação Brasileira das Sociedades de Ginecologia e Obstetrícia (Febrasgo).
} 
17. A América Latina apresenta um grande vazio de leis e regulamentações sobre a pesquisa com células-tronco embrionárias. ${ }^{125}$ Por um lado, esse fenômeno político pode ser explicado pelo baixo potencial tecnológico da região para a condução de pesquisas médicas, com exceção do caso brasileiro; mas, por outro lado, pode também ser um indicativo das forças políticas e religiosas em negociação nos países latino-americanos. Entre os 25 (vinte e cinco) países analisados com marco legal permissivo ou restritivo sobre pesquisas com células-tronco embrionárias, não há qualquer registro de países que tenham associado o debate ético sobre a legitimidade das pesquisas com embriões à metafísica do início da vida humana, tal como vem ocorrendo no Brasil. ${ }^{126}$ Uma possível explicação para essa particularidade regional e, mais especificamente, brasileira no debate sobre células-tronco pode ser encontrada no funcionamento do dispositivo da laicidade nas estruturas básicas do Estado brasileiro. ${ }^{127}$

\section{Parte III}

\section{Liberdade Acadêmica}

1. No Brasil a liberdade acadêmica é uma norma constitucional que garante a liberdade de ensino e pesquisa a professores e pesquisadores. ${ }^{128}$ Diferentemente de outros países democráticos com forte tradição liberal,

\footnotetext{
${ }^{125}$ A Argentina é um país com potencial para a pesquisa com células-tronco na região, mas

não possui lei sobre o tema. O Decreto n. 200 de 1997 proíbe a pesquisa com clonagem humana, sendo o marco normativo que mais se aproxima do debate sobre células-tronco embrionárias.
}
${ }^{126}$ Exceto pela África do Sul, regra geral os países da região africana não possuem estrutura científica razoável para conduzir pesquisas com células-tronco embrionárias. Isso não significa, no entanto, que o tema seja ignorado na pauta de discussões éticas entre os especialistas na região. Em parte devido à extrema pobreza e à falta de assistência à saúde, há um posicionamento favorável às pesquisas com células-tronco em nome de possíveis benefícios à saúde e ao bem-estar, ignorando o marco cristão do debate sobre o início da vida.

TANGWA, Godfrey. Moral status of embryonic stem cells: perspective of an African villager.

Bioethics, London, v. 21, n. 8, p. 449-457, 2007.
${ }^{127}$ DINIZ, Debora; RIOS, Roger Raupp; BUGLIONE, Samantha. Entre a dúvida e o dogma:

liberdade de cátedra e universidades confessionais no Brasil. Brasília/Porto Alegre:

LetrasLivres/Livraria do Advogado, 2006.

\footnotetext{
${ }^{128}$ REPÚBLICA FEDERATIVA DO BRASIL. Constituição (1988). Art. 206. O ensino será ministrado com base nos seguintes princípios. Brasília: Câmara dos Deputados. Coordenação de Publicações, 2005. p. 66. Disponível em: <http://www.camara.gov.br/internet/ Legislacao/Constituicao/CFpdf/constituicao.pdf>. .Acesso em: 17 mar. 2006.
} 
como é o caso dos Estados Unidos e do Canadá, o Direito brasileiro diferencia a liberdade acadêmica de outras garantias e princípios constitucionais, como a liberdade de expressão ou de pensamento. A liberdade acadêmica é um direito específico que protege pesquisadores e professores no exercício de suas atividades. É uma norma voltada para um grupo particular de pessoas e de atividades, cujo cerne é a produção e a distribuição do conhecimento científico. Em termos mais abrangentes, a liberdade acadêmica é um dos instrumentos que promove a educação e a ciência como bens públicos. ${ }^{129}$

2. Mas é o próprio conteúdo da liberdade acadêmica que está em disputa em tempos de pesquisa com células-tronco embrionárias. Há um consenso de que a liberdade acadêmica é a condição de possibilidade para a promoção da ciência, mas qual seria a extensão dessa liberdade e quem constituiria a autoridade legítima para restringi-la são alguns dos pontos centrais da controvérsia em relação à ADIn 3.510. Em grande parte dos 25 (vinte e cinco) países onde se regulamentou a pesquisa com embriões humanos, uma das formas de compreender a liberdade acadêmica foi com base no direito à liberdade de expressão - ou seja, a liberdade acadêmica garante o direito dos professores e pesquisadores à prática científica. Esse foi um mecanismo argumentativo comum em países onde tal liberdade não foi prevista constitucionalmente, como é o caso dos Estados Unidos.

3. A Alemanha reconhece a liberdade de pesquisa como um direito a ser protegido. ${ }^{130}$ Por essa afirmação expressa do direito à pesquisa e por particularidades da história política recente do país, o debate sobre pesquisa com células-tronco embrionárias assumiu contornos muito originais na sociedade alemã. Se o passado nazista dificultou a condução razoável do debate político, a proteção à liberdade de pesquisa não permitiu que a investigação com células-tronco embrionárias fosse banida do país, tal

\footnotetext{
${ }^{129}$ DEWEY, John. Academic freedom. Educational Review, Chicago, n. 23, p.1-14, 1902 ;

DWORKIN, Ronald. We need a new interpretation of academic freedom. In: MENAND, Louis (ed.). The future of academic freedom. Chicago: The University of Chicago Press, 1997. p. 187-198; SCOTT, Joan W. Academic freedom as an ethical practice. In: MENAND,

Louis (ed.). The future of academic freedom. Chicago: The University of Chicago Press, 1997. p. 163-186; RORTY, Richard. Does academic freedom have philosophical presuppositions?. In: MENAND, Louis (ed.). The future of academic freedom. Chicago: The University Of Chicago Press, 1997. p. 21-42.
}

${ }^{130}$ MENAND, Louis. The limits of academic freedom. In: (ed.). The future of academic freedom. Chicago: The University of Chicago Press, 1997. p. 3-20; WEBER, Max.

A ciência como vocação. In: Metodologia das ciências sociais. Tradução:

Agustin

Wernet. São Paulo: Cortez, 1992. p. 431-453. 
como ocorreu na Itália. O resultado foi uma combinação original de dispositivos legais: protege-se a liberdade de pesquisa, mas não se utiliza material genético de origem alemã. ${ }^{131}$

4. Apesar de próximas, liberdade acadêmica e liberdade de expressão anunciam valores éticos diferentes. Ambas pressupõem a liberdade de pensamento, sendo que a liberdade de expressão é garantida a todos os cidadãos, ao passo que a liberdade acadêmica é exclusiva de um grupo de pessoas que realizam atividades específicas. $O$ fato de a liberdade acadêmica ser uma garantia reservada às pessoas envolvidas no ensino e na pesquisa sugere que há algo de singular na prática dessa comunidade e que o apelo à liberdade de expressão não seria suficiente para garantir seus direitos. Além de proteger pesquisadores e professores no exercício de suas atividades, a liberdade acadêmica evidencia a centralidade do conhecimento científico para o progresso social. Assim como a liberdade de expressão, a liberdade acadêmica é uma manifestação da cultura democrática, mas é, também, a garantia de um bem coletivo - a ciência

livre.

5. Qualquer que seja a definição adotada para resumir o objeto de trabalho de pesquisadores e professores - se a busca da verdade, a promoção da ciência ou do conhecimento -, o fato é que somente "uma universidade sem condição", nos termos propostos por Jacques Derrida, será capaz de garantir o progresso social. ${ }^{132}$ Esta é a vocação da universidade: a promoção do conhecimento e o exercício contínuo da dúvida. Não somente a universidade deve se constituir nesse espaço de busca incondicional do conhecimento, como também quem está fora dela precisa dessa certeza para fazer uso dos resultados de pesquisa dos acadêmicos. E essa vocação é particularmente provocada no debate sobre a pesquisa com células-tronco embrionárias, em que a expectativa é que os resultados provoquem uma revolução no conhecimento científico sobre doenças ainda hoje sem tratamento ou cura.

6. Afirmar a incondicionalidade da universidade não significa pressupor um direito absoluto à liberdade acadêmica ou mesmo que a universidade deva ser autônoma em questões legislativas ou políticas que colidam com o ordenamento jurídico vigente. $\mathrm{O}$ caráter incondicional da universidade significa assumir que os limites ao exercício da dúvida serão aqueles impostos pela razoabilidade do sistema constitucional, e não os reclamados por comunidades morais ou religiosas. Por isso, não há como confundir

\footnotetext{
${ }^{131}$ HEINEMANN, Thomas; HONNEFELDER, Ludger. Principles of ethical decision making regarding embryonic stem cells in Germany. BioethicsLondon, v. 16, n. 6, p. 530-542, 2002.

${ }^{132}$ DERRIDA, Jacques. A universidade sem condição. Tradução: Evando Nascimento. São Paulo: Estação Liberdade, 2003. 86 p.
} 
liberdade acadêmica com o princípio niilista do tudo vale. ${ }^{133}$ Sempre haverá restrições à liberdade acadêmica, mas estas são definidas pela razão pública, por acordos constitucionais, e não por valores morais específicos que impeçam o pluralismo razoável. ${ }^{134} \mathrm{O}$ desafio imposto pelo julgamento da constitucionalidade da pesquisa com células-tronco embrionárias é o de traçar a justa fronteira entre razão pública e valores morais abrangentes. ${ }^{135}$

7. O debate razoável de argumentos - traduzido na busca pelas melhoresrespostas, no compromisso com a pesquisa científica e no exercício permanente da dúvida - é o melhor instrumento que a ciência desenvolveu para a promoção de idéias e refutação de teorias, bem como para o julgamento de quais argumentos são melhores que outros para o progresso da ciência. A comunidade acadêmica possui instrumentos variados de julgamento da prática científica, e nem todas as idéias ascendem ao patamar de argumentos legítimos. Portanto, deve se dar em termos estritamente científicos, e não religiosos, a disputa sobre qual o caminho mais promissor de pesquisa sobre células-tronco, se com embrionárias ou com adultas. As hipóteses científicas necessitam ser testadas para que seus resultados tenham validade. Somente a liberdade de pesquisa garantirá o teste de eficácia às células-tronco embrionárias e seu futuro uso terapêutico.

8. Mas a defesa da incondicionalidade da liberdade acadêmica para o progresso científico não pressupõe o revigoramento de valores positivistas como definidores da prática científica em oposição à metafísica religiosa. A confiabilidade e a legitimidade do discurso científico para nosso ordenamento social são garantidas pela liberdade de expressão e pensamento de seus praticantes: é a aposta na liberdade acadêmica que torna a ciência tão poderosa para o debate público. Pesquisadores precisam ser livres para pensar, estudar e divulgar suas idéias, pois é somente em um ambiente de liberdade como um valor público que a missão da universidade, na condição de espaço de profissão com a verdade, pode florescer.

9. Foi em defesa da universidade como o espaço para a inclusão de diferentes perspectivas que Edward Said propôs que o modelo da liberdade acadêmica fosse o do viajante ou migrante, uma metáfora do movimento

${ }^{133}$ FEYERABEND, Paul. La ciencia en una sociedad libre. Tradução: Alberto Elena. 2. ed.

México: Siglo Veintiuno, 1988. 261 p.

${ }^{134}$ CAPPS, Benjamin. Authoritative regulation and the stem cell debate. Bioethics,

London, $\mathrm{v}$.

22, n. 1, p. 43-55, 2008.

${ }^{135}$ RAWLS, John. O liberalismo político. Tradução: Dinah de Abreu Azevedo. Revisão de

tradução: Álvaro de Vita. São Paulo: Ática, 2000. 430 p.; KINTZLER, Catherine.

Tolerancia

y laicismo. Tradução: María Elena Ladd. Buenos Aires: Del Signo, 2005. 64 p. 
intelectual de abertura a novos horizontes e de constantes mudanças do pensamento. A imagem do viajante é a que se contrapõe à figura tradicional do acadêmico como representante da autoridade e do poder. A principal diferença entre o acadêmico-viajante e o acadêmico-potentado é que aquele aposta na inclusão permanente de novas perspectivas, ao passo que este "precisa guardar somente um lugar e defender suas fronteiras". ${ }^{136} \mathrm{E}$ é nessa tensão entre viajantes e potentados que o desafio da liberdade acadêmica se anuncia em meio à controvérsia da pesquisa com embriões humanos.

\section{Conclusões}

1. A pesquisa em 25 (vinte e cinco) países mostrou que a tendência da regulamentação internacional é a de autorizar a pesquisa com célulastronco embrionárias. Dentre as regulamentações mais comuns estão a autorização da pesquisa com embriões congelados remanescentes em clínicas de reprodução assistida; a proibição de comercialização de embriões e de produção de embriões com fins exclusivos de pesquisa; a exigência de que os projetos de pesquisa sejam avaliados por comitês de ética antes da realização dos estudos; e a obrigatoriedade de obtenção do consentimento do casal que produziu o embrião previamente ao seu uso científico. Todas essas proteções éticas foram garantidas pela Lei n. 11.105, que regulamenta a pesquisa com células-tronco embrionárias no Brasil.

2. A tendência internacional de permitir a pesquisa com células-tronco embrionárias deve ser entendida não apenas como uma aposta dos Estados democráticos no progresso da ciência, mas principalmente como uma afirmação ética da soberania do princípio da liberdade de pesquisa para a promoção do conhecimento como um bem público em sociedades democráticas e laicas. No Brasil, a defesa da norma constitucional da liberdade de pesquisa para os cientistas envolvidos na pesquisa com células-tronco embrionárias deve ser entendida com base no marco constitucional dos princípios fundamentais, tais como o da liberdade de pensamento e o da promoção do direito à saúde. A expectativa é de que a pesquisa com células-tronco embrionárias provoque uma revolução no conhecimento científico sobre doenças ainda hoje sem tratamento ou cura. Por uma condição humana compartilhada, todas as pessoas serão beneficiadas pelos resultados dessas pesquisas, muito embora os benefícios mais imediatos sejam esperados para indivíduos em sofrimento.

Pelos argumentos apresentados, a Anis: Instituto de Bioética, Direitos Humanos e Gênero espera que o Supremo Tribunal Federal julgue improcedente o pedido formulado.

Kátia Soares Braga Debora Diniz

Presidente Anis Pesquisadora Anis

Brasília, 26 de maio de 2008.

\footnotetext{
${ }^{136}$ SAID, Edward. Identity, authority, and freedom: the potentate and the traveler. In: MENAND, Louis (ed.). The future of academic freedom. Chicago: The University of Chicago Press, 1997. p. 214-228.
} 


\section{Anexo II}

\section{LEI No 11.105, DE 24 DE MARCO DE 2005.}

$\underline{\text { Mensagem de veto }}$

$\underline{\text { Regulamento }}$
Regulamenta os incisos II, IV e V do $\S$ $1^{\circ}$ do art. 225 da Constituição Federal, estabelece normas de segurança e mecanismos de fiscalização de atividades que envolvam organismos geneticamente modificados - OGM e seus derivados, cria o Conselho Nacional de Biossegurança - CNBS, reestrutura a Comissão Técnica Nacional de Biossegurança - CTNBio, dispõe sobre a Política Nacional de Biossegurança - PNB, revoga a Lei $\mathrm{n}^{\mathrm{o}}$ 8.974, de 5 de janeiro de 1995, e a Medida Provisória n ${ }^{0}$ 2.191-9, de 23 de agosto de 2001 , e os arts. $5^{\circ}, 6^{\underline{o}}, 7^{\underline{0}}, 8^{\underline{o}}$, $9^{\mathrm{O}}, 10$ e 16 da Lei $\mathrm{n}^{\mathrm{o}} 10.814$, de 15 de dezembro de 2003, e dá outras providências.

O PRESIDENTE DA REPÚBLICA Faço saber que o Congresso Nacional decreta e eu sanciono a seguinte Lei:

\section{CAPÍTULO I}

\section{DISPOSIÇÕES PRELIMINARES E GERAIS}

Art. $1^{\underline{0}}$ Esta Lei estabelece normas de segurança e mecanismos de fiscalização sobre a construção, o cultivo, a produção, a manipulação, o transporte, a transferência, a importação, a exportação, o armazenamento, a pesquisa, a comercialização, o consumo, a liberação no meio ambiente e o descarte de organismos geneticamente modificados - OGM e seus derivados, tendo como diretrizes o estímulo ao avanço científico na área de biossegurança e biotecnologia, a proteção à vida e à saúde humana, animal e vegetal, e a observância do princípio da precaução para a proteção do meio ambiente.

$\S 1^{\text {o }}$ Para os fins desta Lei, considera-se atividade de pesquisa a realizada em laboratório, regime de contenção ou campo, como parte do processo de obtenção de OGM e seus derivados ou de avaliação da biossegurança de OGM e seus derivados, o que engloba, no âmbito experimental, a construção, o cultivo, a manipulação, o transporte, a transferência, a importação, a exportação, o armazenamento, a liberação no meio ambiente e o descarte de OGM e seus derivados. 
$\S 2^{\underline{0}}$ Para os fins desta Lei, considera-se atividade de uso comercial de OGM e seus derivados a que não se enquadra como atividade de pesquisa, e que trata do cultivo, da produção, da manipulação, do transporte, da transferência, da comercialização, da importação, da exportação, do armazenamento, do consumo, da liberação e do descarte de OGM e seus derivados para fins comerciais.

Art. $2^{-}$As atividades e projetos que envolvam OGM e seus derivados, relacionados ao ensino com manipulação de organismos vivos, à pesquisa científica, ao desenvolvimento tecnológico e à produção industrial ficam restritos ao âmbito de entidades de direito público ou privado, que serão responsáveis pela obediência aos preceitos desta Lei e de sua regulamentação, bem como pelas eventuais conseqüências ou efeitos advindos de seu descumprimento.

$\S 1^{0}$ Para os fins desta Lei, consideram-se atividades e projetos no âmbito de entidade os conduzidos em instalações próprias ou sob a responsabilidade administrativa, técnica ou científica da entidade.

$\S 2^{0}$ As atividades e projetos de que trata este artigo são vedados a pessoas físicas em atuação autônoma e independente, ainda que mantenham vínculo empregatício ou qualquer outro com pessoas jurídicas.

$\S 3^{0}$ Os interessados em realizar atividade prevista nesta Lei deverão requerer autorização à Comissão Técnica Nacional de Biossegurança CTNBio, que se manifestará no prazo fixado em regulamento.

$\S 4^{0}$ As organizações públicas e privadas, nacionais, estrangeiras ou internacionais, financiadoras ou patrocinadoras de atividades ou de projetos referidos no caput deste artigo devem exigir a apresentação de Certificado de Qualidade em Biossegurança, emitido pela CTNBio, sob pena de se tornarem co-responsáveis pelos eventuais efeitos decorrentes do descumprimento desta Lei ou de sua regulamentação.

Art. $3^{\circ}$ Para os efeitos desta Lei, considera-se:

I - organismo: toda entidade biológica capaz de reproduzir ou transferir material genético, inclusive vírus e outras classes que venham a ser conhecidas;

II - ácido desoxirribonucléico - ADN, ácido ribonucléico - ARN: material genético que contém informações determinantes dos caracteres hereditários transmissíveis à descendência;

III - moléculas de ADN/ARN recombinante: as moléculas manipuladas fora das células vivas mediante a modificação de segmentos de ADN/ARN natural ou sintético e que possam multiplicar-se em uma célula viva, ou ainda as moléculas de ADN/ARN resultantes dessa 
multiplicação; consideram-se também os segmentos de ADN/ARN sintéticos equivalentes aos de ADN/ARN natural;

IV - engenharia genética: atividade de produção e manipulação de moléculas de ADN/ARN recombinante;

$\mathrm{V}$ - organismo geneticamente modificado - OGM: organismo cujo material genético - ADN/ARN tenha sido modificado por qualquer técnica de engenharia genética;

VI - derivado de OGM: produto obtido de OGM e que não possua capacidade autônoma de replicação ou que não contenha forma viável de OGM;

VII - célula germinal humana: célula-mãe responsável pela formação de gametas presentes nas glândulas sexuais femininas e masculinas e suas descendentes diretas em qualquer grau de ploidia;

VIII - clonagem: processo de reprodução assexuada, produzida artificialmente, baseada em um único patrimônio genético, com ou sem utilização de técnicas de engenharia genética;

IX - clonagem para fins reprodutivos: clonagem com a finalidade de obtenção de um indivíduo;

$\mathrm{X}$ - clonagem terapêutica: clonagem com a finalidade de produção de células-tronco embrionárias para utilização terapêutica;

XI - células-tronco embrionárias: células de embrião que apresentam a capacidade de se transformar em células de qualquer tecido de um organismo.

$\S 1^{0}$ Não se inclui na categoria de OGM o resultante de técnicas que impliquem a introdução direta, num organismo, de material hereditário, desde que não envolvam a utilização de moléculas de ADN/ARN recombinante ou OGM, inclusive fecundação in vitro, conjugação, transdução, transformação, indução poliplóide e qualquer outro processo natural.

$\S 2^{\underline{0}}$ Não se inclui na categoria de derivado de OGM a substância pura, quimicamente definida, obtida por meio de processos biológicos e que não contenha OGM, proteína heteróloga ou ADN recombinante.

Art. $4^{\circ}$ Esta Lei não se aplica quando a modificação genética for obtida por meio das seguintes técnicas, desde que não impliquem a utilização de OGM como receptor ou doador:

I - mutagênese;

II - formação e utilização de células somáticas de hibridoma animal; 
III - fusão celular, inclusive a de protoplasma, de células vegetais, que possa ser produzida mediante métodos tradicionais de cultivo;

IV - autoclonagem de organismos não-patogênicos que se processe de maneira natural.

Art. $5^{\underline{0}}$ É permitida, para fins de pesquisa e terapia, a utilização de células-tronco embrionárias obtidas de embriões humanos produzidos por fertilização in vitro e não utilizados no respectivo procedimento, atendidas as seguintes condições:

I - sejam embriões inviáveis; ou

II - sejam embriões congelados há 3 (três) anos ou mais, na data da publicação desta Lei, ou que, já congelados na data da publicação desta Lei, depois de completarem 3 (três) anos, contados a partir da data de congelamento.

$\S 1^{0}$ Em qualquer caso, é necessário o consentimento dos genitores.

$\S 2^{0}$ Instituições de pesquisa e serviços de saúde que realizem pesquisa ou terapia com células-tronco embrionárias humanas deverão submeter seus projetos à apreciação e aprovação dos respectivos comitês de ética em pesquisa.

$\S 3^{0}$ É vedada a comercialização do material biológico a que se refere este artigo e sua prática implica o crime tipificado no art. 15 da Lei $\mathrm{n}^{\circ}$ 9.434, de 4 de fevereiro de 1997.

Art. $6^{\circ}$ Fica proibido:

I - implementação de projeto relativo a OGM sem a manutenção de registro de seu acompanhamento individual;

II - engenharia genética em organismo vivo ou o manejo in vitro de ADN/ARN natural ou recombinante, realizado em desacordo com as normas previstas nesta Lei;

III - engenharia genética em célula germinal humana, zigoto humano e embrião humano;

IV - clonagem humana;

V - destruição ou descarte no meio ambiente de OGM e seus derivados em desacordo com as normas estabelecidas pela CTNBio, pelos órgãos e entidades de registro e fiscalização, referidos no art. 16 desta Lei, e as constantes desta Lei e de sua regulamentação;

VI - liberação no meio ambiente de OGM ou seus derivados, no âmbito de atividades de pesquisa, sem a decisão técnica favorável da CTNBio e, nos casos de liberação comercial, sem o parecer técnico 
favorável da CTNBio, ou sem o licenciamento do órgão ou entidade ambiental responsável, quando a CTNBio considerar a atividade como potencialmente causadora de degradação ambiental, ou sem a aprovação do Conselho Nacional de Biossegurança - CNBS, quando o processo tenha sido por ele avocado, na forma desta Lei e de sua regulamentação;

VII - a utilização, a comercialização, o registro, o patenteamento e o licenciamento de tecnologias genéticas de restrição do uso.

Parágrafo único. Para os efeitos desta Lei, entende-se por tecnologias genéticas de restrição do uso qualquer processo de intervenção humana para geração ou multiplicação de plantas geneticamente modificadas para produzir estruturas reprodutivas estéreis, bem como qualquer forma de manipulação genética que vise à ativação ou desativação de genes relacionados à fertilidade das plantas por indutores químicos externos.

Art. $7^{0}$ São obrigatórias:

I - a investigação de acidentes ocorridos no curso de pesquisas e projetos na área de engenharia genética e o envio de relatório respectivo à autoridade competente no prazo máximo de 5 (cinco) dias a contar da data do evento;

II - a notificação imediata à CTNBio e às autoridades da saúde pública, da defesa agropecuária e do meio ambiente sobre acidente que possa provocar a disseminação de OGM e seus derivados;

III - a adoção de meios necessários para plenamente informar à CTNBio, às autoridades da saúde pública, do meio ambiente, da defesa agropecuária, à coletividade e aos demais empregados da instituição ou empresa sobre os riscos a que possam estar submetidos, bem como os procedimentos a serem tomados no caso de acidentes com OGM.

\section{CAPÍTULO II}

Do Conselho Nacional de Biossegurança - CNBS

Art. $8^{0}$ Fica criado o Conselho Nacional de Biossegurança - CNBS, vinculado à Presidência da República, órgão de assessoramento superior do Presidente da República para a formulação e implementação da Política Nacional de Biossegurança - PNB.

$\S 1^{\circ}$ Compete ao CNBS:

I - fixar princípios e diretrizes para a ação administrativa dos órgãos e entidades federais com competências sobre a matéria;

II - analisar, a pedido da CTNBio, quanto aos aspectos da conveniência e oportunidade socioeconômicas e do interesse nacional, os pedidos de liberação para uso comercial de OGM e seus derivados; 
III - avocar e decidir, em última e definitiva instância, com base em manifestação da CTNBio e, quando julgar necessário, dos órgãos e entidades referidos no art. 16 desta Lei, no âmbito de suas competências, sobre os processos relativos a atividades que envolvam o uso comercial de OGM e seus derivados;

$$
\underline{\mathrm{IV}-(\mathrm{VETADO})}
$$

\section{$\S 2^{\circ}(\mathrm{VETADO})$}

$\S 3^{\text {o }}$ Sempre que o CNBS deliberar favoravelmente à realização da atividade analisada, encaminhará sua manifestação aos órgãos e entidades de registro e fiscalização referidos no art. 16 desta Lei.

$\S 4^{0}$ Sempre que o CNBS deliberar contrariamente à atividade analisada, encaminhará sua manifestação à CTNBio para informação ao requerente.

Art. $9^{\circ} \mathrm{O}$ CNBS é composto pelos seguintes membros:

I - Ministro de Estado Chefe da Casa Civil da Presidência da República, que o presidirá;

II - Ministro de Estado da Ciência e Tecnologia;

III - Ministro de Estado do Desenvolvimento Agrário;

IV - Ministro de Estado da Agricultura, Pecuária e Abastecimento;

V - Ministro de Estado da Justiça;

VI - Ministro de Estado da Saúde;

VII - Ministro de Estado do Meio Ambiente;

VIII - Ministro de Estado do Desenvolvimento, Indústria e Comércio Exterior;

IX - Ministro de Estado das Relações Exteriores;

$\mathrm{X}$ - Ministro de Estado da Defesa;

XI - Secretário Especial de Aqüicultura e Pesca da Presidência da República.

$\S 1^{\circ}$ O CNBS reunir-se-á sempre que convocado pelo Ministro de Estado Chefe da Casa Civil da Presidência da República, ou mediante provocação da maioria de seus membros.

$\S 2^{\circ}(\mathrm{VETADO})$ 
$\S 3^{0}$ Poderão ser convidados a participar das reuniões, em caráter excepcional, representantes do setor público e de entidades da sociedade civil.

$\S 4^{0} \mathrm{O}$ CNBS contará com uma Secretaria-Executiva, vinculada à Casa Civil da Presidência da República.

$\S 5^{\circ}$ A reunião do CNBS poderá ser instalada com a presença de 6 (seis) de seus membros e as decisões serão tomadas com votos favoráveis da maioria absoluta.

\section{CAPÍTULO III}

\section{Da Comissão Técnica Nacional de Biossegurança - CTNBio}

Art. 10. A CTNBio, integrante do Ministério da Ciência e Tecnologia, é instância colegiada multidisciplinar de caráter consultivo e deliberativo, para prestar apoio técnico e de assessoramento ao Governo Federal na formulação, atualização e implementação da PNB de OGM e seus derivados, bem como no estabelecimento de normas técnicas de segurança e de pareceres técnicos referentes à autorização para atividades que envolvam pesquisa e uso comercial de OGM e seus derivados, com base na avaliação de seu risco zoofitossanitário, à saúde humana e ao meio ambiente.

Parágrafo único. A CTNBio deverá acompanhar o desenvolvimento e o progresso técnico e científico nas áreas de biossegurança, biotecnologia, bioética e afins, com o objetivo de aumentar sua capacitação para a proteção da saúde humana, dos animais e das plantas e do meio ambiente.

Art. 11. A CTNBio, composta de membros titulares e suplentes, designados pelo Ministro de Estado da Ciência e Tecnologia, será constituída por 27 (vinte e sete) cidadãos brasileiros de reconhecida competência técnica, de notória atuação e saber científicos, com grau acadêmico de doutor e com destacada atividade profissional nas áreas de biossegurança, biotecnologia, biologia, saúde humana e animal ou meio ambiente, sendo:

I - 12 (doze) especialistas de notório saber científico e técnico, em efetivo exercício profissional, sendo:

a) 3 (três) da área de saúde humana;

b) 3 (três) da área animal;

c) 3 (três) da área vegetal;

d) 3 (três) da área de meio ambiente;

II - um representante de cada um dos seguintes órgãos, indicados pelos respectivos titulares: 
a) Ministério da Ciência e Tecnologia;

b) Ministério da Agricultura, Pecuária e Abastecimento;

c) Ministério da Saúde;

d) Ministério do Meio Ambiente;

e) Ministério do Desenvolvimento Agrário;

f) Ministério do Desenvolvimento, Indústria e Comércio Exterior;

g) Ministério da Defesa;

h) Secretaria Especial de Aqüicultura e Pesca da Presidência da República;

i) Ministério das Relações Exteriores;

III - um especialista em defesa do consumidor, indicado pelo Ministro da Justiça;

IV - um especialista na área de saúde, indicado pelo Ministro da Saúde;

$\mathrm{V}$ - um especialista em meio ambiente, indicado pelo Ministro do Meio Ambiente;

VI - um especialista em biotecnologia, indicado pelo Ministro da Agricultura, Pecuária e Abastecimento;

VII - um especialista em agricultura familiar, indicado pelo Ministro do Desenvolvimento Agrário;

VIII - um especialista em saúde do trabalhador, indicado pelo Ministro do Trabalho e Emprego.

$\S 1^{\circ}$ Os especialistas de que trata o inciso I do caput deste artigo serão escolhidos a partir de lista tríplice, elaborada com a participação das sociedades científicas, conforme disposto em regulamento.

$\S 2^{\circ}$ Os especialistas de que tratam os incisos III a VIII do caput deste artigo serão escolhidos a partir de lista tríplice, elaborada pelas organizações da sociedade civil, conforme disposto em regulamento.

$\S 3^{0}$ Cada membro efetivo terá um suplente, que participará dos trabalhos na ausência do titular.

$\S 4^{-}$Os membros da CTNBio terão mandato de 2 (dois) anos, renovável por até mais 2 (dois) períodos consecutivos. 
$\S 5^{\circ} \mathrm{O}$ presidente da CTNBio será designado, entre seus membros, pelo Ministro da Ciência e Tecnologia para um mandato de 2 (dois) anos, renovável por igual período.

$\S 6^{0}$ Os membros da CTNBio devem pautar a sua atuação pela observância estrita dos conceitos ético-profissionais, sendo vedado participar do julgamento de questões com as quais tenham algum envolvimento de ordem profissional ou pessoal, sob pena de perda de mandato, na forma do regulamento.

$\S 7^{-0}$ A reunião da CTNBio poderá ser instalada com a presença de 14 (catorze) de seus membros, incluído pelo menos um representante de cada uma das áreas referidas no inciso I do caput deste artigo.

\section{$\S 8^{\circ}($ VETADO $)$}

$\S$ 8--A As decisões da CTNBio serão tomadas com votos favoráveis da maioria absoluta de seus membros. (Incluído pela Lei $\mathrm{n}^{\circ} 11.460$, de $\underline{2007)}$

$\S 9^{0}$ Órgãos e entidades integrantes da administração pública federal poderão solicitar participação nas reuniões da CTNBio para tratar de assuntos de seu especial interesse, sem direito a voto.

$\S 10$. Poderão ser convidados a participar das reuniões, em caráter excepcional, representantes da comunidade científica e do setor público e entidades da sociedade civil, sem direito a voto.

Art. 12. O funcionamento da CTNBio será definido pelo regulamento desta Lei.

$\S 1^{\circ}$ A CTNBio contará com uma Secretaria-Executiva e cabe ao Ministério da Ciência e Tecnologia prestar-lhe o apoio técnico e administrativo.

\section{$\S 2^{\circ}($ VETADO $)$}

Art. 13. A CTNBio constituirá subcomissões setoriais permanentes na área de saúde humana, na área animal, na área vegetal e na área ambiental, e poderá constituir subcomissões extraordinárias, para análise prévia dos temas a serem submetidos ao plenário da Comissão.

$\S 1^{0}$ Tanto os membros titulares quanto os suplentes participarão das subcomissões setoriais e caberá a todos a distribuição dos processos para análise.

$\S 2^{\underline{0}} \mathrm{O}$ funcionamento e a coordenação dos trabalhos nas subcomissões setoriais e extraordinárias serão definidos no regimento interno da CTNBio.

Art. 14. Compete à CTNBio: 

OGM;

I - estabelecer normas para as pesquisas com OGM e derivados de

II - estabelecer normas relativamente às atividades e aos projetos relacionados a OGM e seus derivados;

III - estabelecer, no âmbito de suas competências, critérios de avaliação e monitoramento de risco de OGM e seus derivados;

IV - proceder à análise da avaliação de risco, caso a caso, relativamente a atividades e projetos que envolvam OGM e seus derivados;

$\mathrm{V}$ - estabelecer os mecanismos de funcionamento das Comissões Internas de Biossegurança - CIBio, no âmbito de cada instituição que se dedique ao ensino, à pesquisa científica, ao desenvolvimento tecnológico e à produção industrial que envolvam OGM ou seus derivados;

VI - estabelecer requisitos relativos à biossegurança para autorização de funcionamento de laboratório, instituição ou empresa que desenvolverá atividades relacionadas a OGM e seus derivados;

VII - relacionar-se com instituições voltadas para a biossegurança de OGM e seus derivados, em âmbito nacional e internacional;

VIII - autorizar, cadastrar e acompanhar as atividades de pesquisa com OGM ou derivado de OGM, nos termos da legislação em vigor;

IX - autorizar a importação de OGM e seus derivados para atividade de pesquisa;

$\mathrm{X}$ - prestar apoio técnico consultivo e de assessoramento ao CNBS na formulação da PNB de OGM e seus derivados;

XI - emitir Certificado de Qualidade em Biossegurança - CQB para o desenvolvimento de atividades com OGM e seus derivados em laboratório, instituição ou empresa e enviar cópia do processo aos órgãos de registro e fiscalização referidos no art. 16 desta Lei;

XII - emitir decisão técnica, caso a caso, sobre a biossegurança de OGM e seus derivados no âmbito das atividades de pesquisa e de uso comercial de OGM e seus derivados, inclusive a classificação quanto ao grau de risco e nível de biossegurança exigido, bem como medidas de segurança exigidas e restrições ao uso;

XIII - definir o nível de biossegurança a ser aplicado ao OGM e seus usos, e os respectivos procedimentos e medidas de segurança quanto ao seu uso, conforme as normas estabelecidas na regulamentação desta Lei, bem como quanto aos seus derivados;

XIV - classificar os OGM segundo a classe de risco, observados os critérios estabelecidos no regulamento desta Lei; 
$\mathrm{XV}$ - acompanhar o desenvolvimento e o progresso técnico-científico na biossegurança de OGM e seus derivados;

XVI - emitir resoluções, de natureza normativa, sobre as matérias de sua competência;

XVII - apoiar tecnicamente os órgãos competentes no processo de prevenção e investigação de acidentes e de enfermidades, verificados no curso dos projetos e das atividades com técnicas de ADN/ARN recombinante;

XVIII - apoiar tecnicamente os órgãos e entidades de registro e fiscalização, referidos no art. 16 desta Lei, no exercício de suas atividades relacionadas a OGM e seus derivados;

XIX - divulgar no Diário Oficial da União, previamente à análise, os extratos dos pleitos e, posteriormente, dos pareceres dos processos que the forem submetidos, bem como dar ampla publicidade no Sistema de Informações em Biossegurança - SIB a sua agenda, processos em trâmite, relatórios anuais, atas das reuniões e demais informações sobre suas atividades, excluídas as informações sigilosas, de interesse comercial, apontadas pelo proponente e assim consideradas pela CTNBio;

XX - identificar atividades e produtos decorrentes do uso de OGM e seus derivados potencialmente causadores de degradação do meio ambiente ou que possam causar riscos à saúde humana;

XXI - reavaliar suas decisões técnicas por solicitação de seus membros ou por recurso dos órgãos e entidades de registro e fiscalização, fundamentado em fatos ou conhecimentos científicos novos, que sejam relevantes quanto à biossegurança do OGM ou derivado, na forma desta Lei e seu regulamento;

XXII - propor a realização de pesquisas e estudos científicos no campo da biossegurança de OGM e seus derivados;

XXIII - apresentar proposta de regimento interno ao Ministro da Ciência e Tecnologia.

$\S 1^{\circ}$ Quanto aos aspectos de biossegurança do OGM e seus derivados, a decisão técnica da CTNBio vincula os demais órgãos e entidades da administração.

$\S 2^{0}$ Nos casos de uso comercial, dentre outros aspectos técnicos de sua análise, os órgãos de registro e fiscalização, no exercício de suas atribuições em caso de solicitação pela CTNBio, observarão, quanto aos aspectos de biossegurança do OGM e seus derivados, a decisão técnica da CTNBio. 
$\S 3^{0}$ Em caso de decisão técnica favorável sobre a biossegurança no âmbito da atividade de pesquisa, a CTNBio remeterá o processo respectivo aos órgãos e entidades referidos no art. 16 desta Lei, para o exercício de suas atribuições.

$\S 4^{0}$ A decisão técnica da CTNBio deverá conter resumo de sua fundamentação técnica, explicitar as medidas de segurança e restrições ao uso do OGM e seus derivados e considerar as particularidades das diferentes regiões do País, com o objetivo de orientar e subsidiar os órgãos e entidades de registro e fiscalização, referidos no art. 16 desta Lei, no exercício de suas atribuições.

$\S 5^{0}$ Não se submeterá a análise e emissão de parecer técnico da CTNBio o derivado cujo OGM já tenha sido por ela aprovado.

$\S 6^{0}$ As pessoas físicas ou jurídicas envolvidas em qualquer das fases do processo de produção agrícola, comercialização ou transporte de produto geneticamente modificado que tenham obtido a liberação para uso comercial estão dispensadas de apresentação do $\mathrm{CQB}$ e constituição de CIBio, salvo decisão em contrário da CTNBio.

Art. 15. A CTNBio poderá realizar audiências públicas, garantida participação da sociedade civil, na forma do regulamento.

Parágrafo único. Em casos de liberação comercial, audiência pública poderá ser requerida por partes interessadas, incluindo-se entre estas organizações da sociedade civil que comprovem interesse relacionado à matéria, na forma do regulamento.

\section{CAPÍTULO IV}

Dos órgãos e entidades de registro e fiscalização

Art. 16. Caberá aos órgãos e entidades de registro e fiscalização do Ministério da Saúde, do Ministério da Agricultura, Pecuária e Abastecimento e do Ministério do Meio Ambiente, e da Secretaria Especial de Aqüicultura e Pesca da Presidência da República entre outras atribuições, no campo de suas competências, observadas a decisão técnica da CTNBio, as deliberações do CNBS e os mecanismos estabelecidos nesta Lei e na sua regulamentação:

I - fiscalizar as atividades de pesquisa de OGM e seus derivados; derivados;

II - registrar e fiscalizar a liberação comercial de OGM e seus

III - emitir autorização para a importação de OGM e seus derivados para uso comercial; 
IV - manter atualizado no SIB o cadastro das instituições e responsáveis técnicos que realizam atividades e projetos relacionados a OGM e seus derivados;

$\mathrm{V}$ - tornar públicos, inclusive no SIB, os registros e autorizações concedidas;

VI - aplicar as penalidades de que trata esta Lei;

VII - subsidiar a CTNBio na definição de quesitos de avaliação de biossegurança de OGM e seus derivados.

$\S 1^{0}$ Após manifestação favorável da CTNBio, ou do CNBS, em caso de avocação ou recurso, caberá, em decorrência de análise específica e decisão pertinente:

I - ao Ministério da Agricultura, Pecuária e Abastecimento emitir as autorizações e registros e fiscalizar produtos e atividades que utilizem OGM e seus derivados destinados a uso animal, na agricultura, pecuária, agroindústria e áreas afins, de acordo com a legislação em vigor e segundo o regulamento desta Lei;

II - ao órgão competente do Ministério da Saúde emitir as autorizações e registros e fiscalizar produtos e atividades com OGM e seus derivados destinados a uso humano, farmacológico, domissanitário e áreas afins, de acordo com a legislação em vigor e segundo o regulamento desta Lei;

III - ao órgão competente do Ministério do Meio Ambiente emitir as autorizações e registros e fiscalizar produtos e atividades que envolvam OGM e seus derivados a serem liberados nos ecossistemas naturais, de acordo com a legislação em vigor e segundo o regulamento desta Lei, bem como o licenciamento, nos casos em que a CTNBio deliberar, na forma desta Lei, que o OGM é potencialmente causador de significativa degradação do meio ambiente;

IV - à Secretaria Especial de Aqüicultura e Pesca da Presidência da República emitir as autorizações e registros de produtos e atividades com OGM e seus derivados destinados ao uso na pesca e aqüicultura, de acordo com a legislação em vigor e segundo esta Lei e seu regulamento.

$\S 2^{-}$Somente se aplicam as disposições dos incisos I e II do art. $8^{\circ}$ e do caput do art. 10 da Lei $\mathrm{n}^{\mathrm{o}}$ 6.938, de 31 de agosto de 1981, nos casos em que a CTNBio deliberar que o OGM é potencialmente causador de significativa degradação do meio ambiente.

$\S 3^{0}$ A CTNBio delibera, em última e definitiva instância, sobre os casos em que a atividade é potencial ou efetivamente causadora de degradação ambiental, bem como sobre a necessidade do licenciamento ambiental. 
$\S 4^{0}$ A emissão dos registros, das autorizações e do licenciamento ambiental referidos nesta Lei deverá ocorrer no prazo máximo de 120 (cento e vinte) dias.

$\S 5^{\circ}$ A contagem do prazo previsto no $\S 4^{\circ}$ deste artigo será suspensa, por até 180 (cento e oitenta) dias, durante a elaboração, pelo requerente, dos estudos ou esclarecimentos necessários.

$\S 6^{-}$As autorizações e registros de que trata este artigo estarão vinculados à decisão técnica da CTNBio correspondente, sendo vedadas exigências técnicas que extrapolem as condições estabelecidas naquela decisão, nos aspectos relacionados à biossegurança.

$\S 7^{0}$ Em caso de divergência quanto à decisão técnica da CTNBio sobre a liberação comercial de OGM e derivados, os órgãos e entidades de registro e fiscalização, no âmbito de suas competências, poderão apresentar recurso ao CNBS, no prazo de até 30 (trinta) dias, a contar da data de publicação da decisão técnica da CTNBio.

\section{CAPÍTULO V}

Da Comissão Interna de Biossegurança - CIBio

Art. 17. Toda instituição que utilizar técnicas e métodos de engenharia genética ou realizar pesquisas com OGM e seus derivados deverá criar uma Comissão Interna de Biossegurança - CIBio, além de indicar um técnico principal responsável para cada projeto específico.

Art. 18. Compete à CIBio, no âmbito da instituição onde constituída:

I - manter informados os trabalhadores e demais membros da coletividade, quando suscetíveis de serem afetados pela atividade, sobre as questões relacionadas com a saúde e a segurança, bem como sobre os procedimentos em caso de acidentes;

II - estabelecer programas preventivos e de inspeção para garantir o funcionamento das instalações sob sua responsabilidade, dentro dos padrões e normas de biossegurança, definidos pela CTNBio na regulamentação desta Lei;

III - encaminhar à CTNBio os documentos cuja relação será estabelecida na regulamentação desta Lei, para efeito de análise, registro ou autorização do órgão competente, quando couber;

IV - manter registro do acompanhamento individual de cada atividade ou projeto em desenvolvimento que envolvam OGM ou seus derivados;

$\mathrm{V}$ - notificar à CTNBio, aos órgãos e entidades de registro e fiscalização, referidos no art. 16 desta Lei, e às entidades de trabalhadores o resultado de avaliações de risco a que estão submetidas as pessoas expostas, 
bem como qualquer acidente ou incidente que possa provocar a disseminação de agente biológico;

VI - investigar a ocorrência de acidentes e as enfermidades possivelmente relacionados a OGM e seus derivados e notificar suas conclusões e providências à CTNBio.

\section{CAPÍTULO VI}

Do Sistema de Informações em Biossegurança - SIB

Art. 19. Fica criado, no âmbito do Ministério da Ciência e Tecnologia, o Sistema de Informações em Biossegurança - SIB, destinado à gestão das informações decorrentes das atividades de análise, autorização, registro, monitoramento e acompanhamento das atividades que envolvam OGM e seus derivados.

$\S 1^{\underline{0}}$ As disposições dos atos legais, regulamentares e administrativos que alterem, complementem ou produzam efeitos sobre a legislação de biossegurança de OGM e seus derivados deverão ser divulgadas no SIB concomitantemente com a entrada em vigor desses atos.

$\S 2^{2}$ Os órgãos e entidades de registro e fiscalização, referidos no art. 16 desta Lei, deverão alimentar o SIB com as informações relativas às atividades de que trata esta Lei, processadas no âmbito de sua competência.

\section{CAPÍTULO VII}

Da Responsabilidade Civil e Administrativa

Art. 20. Sem prejuízo da aplicação das penas previstas nesta Lei, os responsáveis pelos danos ao meio ambiente e a terceiros responderão, solidariamente, por sua indenização ou reparação integral, independentemente da existência de culpa.

Art. 21. Considera-se infração administrativa toda ação ou omissão que viole as normas previstas nesta Lei e demais disposições legais pertinentes.

Parágrafo único. As infrações administrativas serão punidas na forma estabelecida no regulamento desta Lei, independentemente das medidas cautelares de apreensão de produtos, suspensão de venda de produto e embargos de atividades, com as seguintes sanções:

I - advertência;

II - multa;

III - apreensão de OGM e seus derivados;

IV - suspensão da venda de OGM e seus derivados; 
$\mathrm{V}$ - embargo da atividade;

VI - interdição parcial ou total do estabelecimento, atividade ou empreendimento;

VII - suspensão de registro, licença ou autorização;

VIII - cancelamento de registro, licença ou autorização;

IX - perda ou restrição de incentivo e benefício fiscal concedidos pelo governo;

$\mathrm{X}$ - perda ou suspensão da participação em linha de financiamento em estabelecimento oficial de crédito;

XI - intervenção no estabelecimento;

XII - proibição de contratar com a administração pública, por período de até 5 (cinco) anos.

Art. 22. Compete aos órgãos e entidades de registro e fiscalização, referidos no art. 16 desta Lei, definir critérios, valores e aplicar multas de $\mathrm{R} \$ 2.000,00$ (dois mil reais) a $\mathrm{R} \$ 1.500 .000,00$ (um milhão e quinhentos mil reais), proporcionalmente à gravidade da infração.

$\S 1^{0}$ As multas poderão ser aplicadas cumulativamente com as demais sanções previstas neste artigo.

$\S 2^{\circ}$ No caso de reincidência, a multa será aplicada em dobro.

$\S 3^{0}$ No caso de infração continuada, caracterizada pela permanência da ação ou omissão inicialmente punida, será a respectiva penalidade aplicada diariamente até cessar sua causa, sem prejuízo da paralisação imediata da atividade ou da interdição do laboratório ou da instituição ou empresa responsável.

Art. 23. As multas previstas nesta Lei serão aplicadas pelos órgãos e entidades de registro e fiscalização dos Ministérios da Agricultura, Pecuária e Abastecimento, da Saúde, do Meio Ambiente e da Secretaria Especial de Aqüicultura e Pesca da Presidência da República, referidos no art. 16 desta Lei, de acordo com suas respectivas competências.

$\S 1^{\underline{0}}$ Os recursos arrecadados com a aplicação de multas serão destinados aos órgãos e entidades de registro e fiscalização, referidos no art. 16 desta Lei, que aplicarem a multa.

$\S 2^{0}$ Os órgãos e entidades fiscalizadores da administração pública federal poderão celebrar convênios com os Estados, Distrito Federal e Municípios, para a execução de serviços relacionados à atividade de fiscalização prevista nesta Lei e poderão repassar-lhes parcela da receita obtida com a aplicação de multas. 
$\S 3^{\circ}$ A autoridade fiscalizadora encaminhará cópia do auto de infração à CTNBio.

$\S 4^{\underline{0}}$ Quando a infração constituir crime ou contravenção, ou lesão à Fazenda Pública ou ao consumidor, a autoridade fiscalizadora representará junto ao órgão competente para apuração das responsabilidades administrativa e penal.

CAPÍTULO VIII

Dos Crimes e das Penas

Art. 24. Utilizar embrião humano em desacordo com o que dispõe o art. $5^{\circ}$ desta Lei:

Pena - detenção, de 1 (um) a 3 (três) anos, e multa.

Art. 25. Praticar engenharia genética em célula germinal humana, zigoto humano ou embrião humano:

Pena - reclusão, de 1 (um) a 4 (quatro) anos, e multa.

Art. 26. Realizar clonagem humana:

Pena - reclusão, de 2 (dois) a 5 (cinco) anos, e multa.

Art. 27. Liberar ou descartar OGM no meio ambiente, em desacordo com as normas estabelecidas pela CTNBio e pelos órgãos e entidades de registro e fiscalização:

Pena - reclusão, de 1 (um) a 4 (quatro) anos, e multa.

\section{$\S 1^{\circ}(\mathrm{VETADO})$}

$\S 2^{0}$ Agrava-se a pena:

I - de 1/6 (um sexto) a 1/3 (um terço), se resultar dano à propriedade alheia;

II - de 1/3 (um terço) até a metade, se resultar dano ao meio ambiente;

III - da metade até $2 / 3$ (dois terços), se resultar lesão corporal de natureza grave em outrem;

IV - de 2/3 (dois terços) até o dobro, se resultar a morte de outrem.

Art. 28. Utilizar, comercializar, registrar, patentear e licenciar tecnologias genéticas de restrição do uso:

Pena - reclusão, de 2 (dois) a 5 (cinco) anos, e multa.

Art. 29. Produzir, armazenar, transportar, comercializar, importar ou exportar OGM ou seus derivados, sem autorização ou em desacordo com as 
normas estabelecidas pela CTNBio e pelos órgãos e entidades de registro e fiscalização:

Pena - reclusão, de 1 (um) a 2 (dois) anos, e multa. (...)

Art. 42. Revogam-se a Lei ${ }^{0} 8.974$, de 5 de janeiro de 1995, a Medida Provisória $n^{\circ} 2.191-9$, de 23 de agosto de 2001 , e os arts. $5^{\circ}, 6^{\circ}, 7^{\circ}, 8^{\circ}, 9^{\circ}$, $\underline{10}$ e $\underline{16}$ da Lei $\mathrm{n}^{\mathrm{o}} 10.814$, de 15 de dezembro de 2003.

Brasília, 24 de março de 2005; $184^{\circ}$ da Independência e $117^{0}$ da República.

\section{LUIZ INÁCIO LULA DA SILVA}

Márcio Thomaz Bastos

Celso Luiz Nunes Amorim

Roberto Rodrigues

Humberto Sérgio Costa Lima

Luiz Fernando Furlan

Patrus Ananias

Eduardo Campos

Marina Silva

Miguel Soldatelli Rossetto

José Dirceu de Oliveira e Silva

Este texto não substitui o publicado no D.O.U. de 28.3.2005. 


\section{Anexo III}

\section{EXCELENTÍSSIMO SENHOR MINISTRO PRESIDENTE DO SUPREMO \\ TRIBUNAL \\ FEDERAL:}

O Procurador Geral da República, presente o disposto no artigo 102, I, a, da Constituição Federal, ajuíza.

Ação Direta de Inconstitucionalidade, pelo que expõe:

\section{Do preceito normativo impugnado:}

1. É o que se faz presente no artigo $5^{\circ}$ e parágrafos da Lei ${ }^{\circ} 11.105$, de 24 de março de 2005, verbis:

“Art. 5 É permitida, para fins de pesquisa e terapia, a utilização de célulastronco embrionárias obtidas de embriões humanos produzidos por fertilização in vitro e não utilizados no respectivos procedimento, atendidas as seguintes condições:

I - sejam embriões inviáveis; ou

II - sejam embriões congelados há 3 (três) anos ou mais, na data de publicação desta Lei, ou que, já congelados na data da publicação desta Lei, depois de completarem 3 (três) anos, contados a partir da data de congelamento.

$\S 1^{\mathrm{o}}$ Em qualquer caso, é necessário o consentimento dos genitores.

$\S 2^{\circ}$ Instituições de pesquisa e serviços de saúde que realizem pesquisas ou terapia com células-tronco embrionárias humanas $n .{ }^{\circ}$ deverão submeter seus projetos à apreciação e aprovação dos respectivos comitês de ética e pesquisa.

$\S 3^{\circ}$ É verdade a comercialização do material biológico a que se refere este artigo e sua prática implica o crime tipificado no art. 15 da Lei $n^{\circ} 9.434$, de 4 de fevereiro de 1997".

\section{Dos textos constitucionais inobservados pelo preceito retro transcrito:}

1.Dispõe o artigo $5^{\circ}$, caput, verbis:

Artigo $5^{\circ}$ - Todos são iguais perante a lei, sem distorção de qualquer natureza, garantindo-se aos brasileiros e aos estrangeiros residentes no País 
a inviolabilidade do direito à vida, à liberdade, à igualdade, à segurança e à propriedade, nos termos seguintes:

(grifei)

2. Dispõe o artigo $\mathbf{1}^{\mathbf{0}}$, inciso III, verbis:

Artigo $1^{\circ}$ - A República Federativa Brasil, formada pela união indissolúvel dos Estados e Municípios e do Distrito Federal, constituise em Estado democrático de direito e tem como fundamentos:

III - a dignidade da pessoa humana.

III - Da fundamentação por Inconstitucionalidade material:

1. A tese central desta petição afirma que a vida humana acontece na, e a partir da, fecundação.

2. Assim, a lição do Dr. Dernival da Silva Brandão, especialista em Ginecologia e Membro Emérito da Academia Fluminense de Medicina, verbis:

"O embrião é o ser humano na fase inicial de sua vida. É um ser humano em virtude de sua constituição genética específica própria e de ser gerado por um casal humano através de gametas humanos - espermatozóide e óvulo. Compreende a fase de desenvolvimento que vai desde a concepção, com a formação do zigoto na união dos gametas, até completar a oitava semana de vida. Desde o primeiro momento de sua existência esse novo ser já tem determinado as suas características pessoais fundamentais como sexo, grupo sanguíneo, cor da pele e dos olhos, etc. É o agente do seu próprio desenvolvimento, coordenado de acordo com o seu próprio código genético.

O cientista Jérôme Lejeune, professor da universidade de René Descartes, em Paris, que dedicou toda a sua vida ao estudo da genética fundamental, descobridor da Síndrome de Dawn (mongolismo), nos diz: "Não quero repetir o óbvio, mas, na verdade, a vida começa na fecundação. Quando os 23 cromossomos masculinos se encontram com os 23 cromossomos da mulher, todos os dados genéticos que definem o novo ser humano estão presentes. A fecundação é o marco do início da vida. Daí para frente, qualquer método artificial para destruí-la é um assassinato".

(publicação: VIDA: o primeiro direito da cidadania - pg. 10 - em anexo, grifei)

3. E prossegue o Dr. Dernival Brandão, verbis:

A ciência demonstra insofismamavelmente - com os recursos mais modernos - que o ser humano, recém-fecundado, tem já o seu próprio 
patrimônio genético e o seu próprio sistema imunológico diferente da mãe. É o mesmo ser humano - e não outro - que depois se converterá em bebê, criança, jovem, adulto e ancião. $\mathrm{O}$ processo vai-se desenvolvendo suavemente, sem saltos, sem nenhuma mudança qualitativa. Não é cientificamente admissível que o produto da fecundação seja nos primeiros momentos somente uma "matéria germinante". Aceitar, portanto, que depois da fecundação existe um novo ser humano, independente, não é uma hipótese metafísica, mas uma evidência experimental. Nunca se poderá falar de embrião como de uma "pessoa em potencial" que está em processo de personalização e que nas primeiras semanas pode ser abortada. Porque? Poderíamos perguntar-nos: em que momento, em que dia, em que semana começa a ter a qualidade de um ser humano? Hoje não é; amanhã já é. Isto, obviamente, é cientificamente absurdo." (publicação citada - pg. 11, grifei)

4. O Dr. Dalton Luiz de Paula Ramos, livre-docente pela Universidade de S.Paulo, Professsor de Bioética da USP e Membro do Núcleo Interdisciplinar de Biotética da UNIFESP acentua que, verbis:

"Os biólogos empregam diferentes termos - como por exemplo zigoto, embrião, feto, etc-, para caracterizar diferentes etapas da evolução do óvulo fecundo. Todavia esses diferentes nomes não conferem diferentes dignidades a essas diversas etapas.

Mesmo não sendo possível distinguir nas fases iniciais os formatos humanos, nessa nova vida se encontram todas as informações, que se chama "código genético", suficientes para que o embrião saiba como fazer para se desenvolver. Ninguém mais, mesmo a mãe, vai interferir nesses processos de ampliação do novo ser. A mãe, por meio de seu corpo, vai oferecer a essa nova vida um ambiente adequado (o útero) e os nutrientes necessários. Mas é o embrião que administra a construção e executa a obra. Logo, o embrião não é "da mãe"; ele tem vida própria. $O$ embrião "está" na mãe, que o acolhe pois o ama.

Não se trata, então, de um simples amontoado de células. $O$ embrião é vida humana.

A partir do momento que, alcançando maior tamanho e desenvolvimento físico, passamos a reconhecer aqueles formatos humanos (cabeça, tronco, mãos e braços, pernas e pés, etc), podemos chamar essa nova vida humana de "feto"."

(publicação citada - pg. 12/13 grifei)

5. A Dra. Alice Teixeira Ferreira, Professora Associada de Biofísica da UNIFESP/EPM na área de Biologia Celular-Sinalização Celular afirma, verbis: 
"Embriologia quer dizer o estudo dos embriões, entretanto, se refere, atualmente, ao estudo do desenvolvimento de embriões e fetos. Surgiu com o aumento da sensibilidade dos microscópios. Karl Ernst Von Baer observou, em 1827, o ovo ou zigoto em divisão na tuba uterina e o blastocisto no útero de animais, Nas suas obras Ueber Entwicklungsgeschiechteb der Tiere e Beabachutung and Reflexion escreveu os estágios correspondentes do desenvovimento do embrião e quais as características gerais que precedem as específicas, contribuindo com novos conhecimentos sobre a origem dos tecidos e órgãos. Por isto é chamado de "Pai da Embriologia Moderna".

Em 1839 Schleiden e Schwan, ao formularem a Teoria Celular, foram responsáveis por grandes avanços da Embriologia. Conforme tal conceito o corpo é composto por células o que leva à compreensão de que o embrião se forma à partir de uma ÚNICA célula, o zigoto, que por muitas divisões celulares forma os tecidos e órgãos de todo ser vivo, em particular o humano.

Confirmando tais fatos, em 1879, Hertwig descreveu eventos visíveis na união do óvulo ou ovócito com o espermatozóide em mamíferos.

Para não se dizer que se trata de conceitos ultrapassados verifiquei que TODOS os textos de Embriologia Humana consultados (as últimas edições listadas na Referência Biográfica) afirmam que o desenvolvimento humano se inicia quando o ovócito é fertilização pelo espermatozóide. Todos afirmam que o desenvolvimento humano é a expressão do fluxo irreversível de eventos biológicos ao longo do tempo que só para com a morte. Todos nós passamos pelas mesmas fases do desenvolvimentos intrauterino: fomos um ovo, uma mórula, um blastocisto, um feto."

6. A Dra. Elizabeth Kipman Cerqueira, perita em sexualidade humana e especialista em logoterapia escreve, verbis:

"O zigoto, constituído por uma única célula produz imediatamente proteínas e enzimas humanas e não de outra espécie. É biologicamente um indivíduo único e irrepetível, um organismos vivo pertecente à espécie humana.

b) "O tipo genético - as características herdadas de um ser humano individualizado - é estabelecido no processo da concepção e permanecerá em vigor por toda a vida daquele indivíduo" (Shettles e Rorvik - Rites of Life, Grand Rapids (MI), Zondervan, 1983 - cf. Pastuszek: Is Fetus Human - pg. 5." 
"O desenvolvimento humano se inicia na fertilização, o processo durante o qual um gameta masculino ou espermatozóide (...) se une a um gameta feminino ou ovócito (...) para formar uma célula única chamada zigoto. Esta célula altamente especializada e totipotente marca o início de cada um de nós, como indivíduo único. (Keith Moore e T.V.N Persaud - The Developing Human, Philadelphia, W.B. Saunders Company - 1998 - pg.18

7. Anexo quadro esquemático que na, e a partir da, fecundação marca o desenvolvimento da vida humana: o zigoto, que se desenvolve a partir de sua unicidade celular. (vide: quadro anexo).

8. Importa, agora, abordar o tema das células-tronco.

9. Diz a Dra. Alice Teixeira Ferreira, verbis:

As células tronco embrionárias são aquelas provenientes da massa celular interna do embrião (blastocisto). São chamadas de células-tronco embrionárias humanas porque provêm do embrião e porque são célulasmães do ser humano. Para se usar estas células, que constituem a massa interna do blastocisto, é destruído o embrião.

As células tronco adultas são aquelas encontradas em todos os órgãos e em maior quantidade na medula óssea (tutano do osso) e no cordão umbilical-placenta. No tutano dos ossos tem-se a produção de milhões de células por dia, que substituem as que morrem diariamente no sangue." (publicação citada - pg. 33, grifei)

10. O Dr. Herbert Praxedes também considera que, verbis:

"As células de um embrião humano de poucos dias são todas célulastronco (CTE), são pluripotenciais, tendo capacidade de se autorenovarem e de se diferenciarem em qualquer dos tecidos do corpo. As células-tronco adultas (CTA) são multipotenciais e têm também capacidade de ser autorenovarem e se diferenciarem em vários, mas, aparente não em todos, os tecidos do organismo. As CTA existem no organismo adulto em vários tecidos como a medula óssea, pele, tecido nervoso, e outros, e também são encontradas em grande concentração no sangue do cordão umbilical."

(publicação citada pg. 33 grifei)

11. O Professor Titular de Cirurgia da Universidade Autônoma de Madrid, Dr. Damián Garcia-Olmo, em entrevista, realçou os avanços muito mais promissores da pesquisa científica com células-tronco adultas, do que com as embrionárias.

12. Principia por apresentar quadro real de tratamento de pacientes, curados da enfermidade de Crohn, verbis: 
--Usted ha desarrollado uma investigación sobre el tratamiento de algunas enfermedades com células madre adultas, y parece haber obtenido buenos resultados.

-- En el Departamento de Cirugía del Hospital Universitario La Paz de Madrid estamos desarrollando un estudio sobre el uso de células madre autólogas (del proprio individuo) para el tratamiento de las fístulas en la enfermedad de Crohn ( Una efermedad inflamatoria intestinal que aumenta rápidamente de incidencia en países desarrollados y que afecta sobre todo a jóvenes). La aparición de fístulas en la enfermedad de Crohn es una importante causa de sufrimientos por su gran resistencia a curar com los tratamientos clásicos. Por outra parte, a partit del año 2001, la terapia celular se esta introduciendo rápidamente en muchas ramas de la medicina, en especial desde la introducción del uso de células madre adultas. Esto permite el autotrasplante (trasplante autólogo) sin problemas de rechazo y obvia los graves problemas clínicos y éticos del uso de células madre de origen embrionario. Com el estudio que estamos desarrollando nos proponemos conecer si es posible y seguro utilizar células adultas en el tratamiento de las fístulas que aparecen en los pacientes com enfermedad de Crohn.

--Damián García-Olmo: En determinados pacientes com esta enfermedad, realizamos una liposucción de $100 \mathrm{cc}$ de grasa subdérmica. De esta grasa extraemos una pequeña cantidad de células madre que posteriormente son expandidas en cultivo (ex - vivo). Cuando han crecido y tenemos un número suficiente, se realiza la intervención quirúrgica de la fístula siguiendo los métodos habituales, pero ademais se inyectan en diferentes puntos del trayecto fistuloso entre 9 y 12 millones de estas células madre autólogas cultivadas.

-- Cuál es la experiencia actual?

--Desde que se obtuvieron todos los permisos legales y se comenzó la fase clínica, dos pacientes han completado el seguimiento programado, alcanzando temporalmente la curación completa de la enfermedad fistulosa. Se trataba de uma fístula recto-vaginal y de una fístula enterocutánea, ambas en mujeres jóvenes u con numerosas operaciones previas fracasadas por esa misma causa.

Del seguimento de estos enfermos podemos deducir que: $1 \S$ Por liposucción podemos obtener un suficiente número de células madre. $2 \S$.Estas células se reproducen bien en cultivo y entre 5 y 7 días se obtiene una cantidad suficiente para su uso clínico. $3 \S$.- La inyección celular no produjo en ningún momento fenómenos de rechazo. $4 \S$.- No se há producido un crecimiento celular incontrolado que suponga riesgo tumoral. 5 §.- Los 
efectos reparadores de esta terapia parecen comenzar al cabo de 4-8 semanas de la inyección.

13. Depois, demonstra a superação do preconceito científico contra as células-tronco adultas, a partir do trabalho da Professora Catherine Verfaillie. De se ler, verbis:

--En qúe punto esta actualmente la investigación com celulas madres adultas?

--El año 2002 ha sido um año clave. Tanto que ha dado um vuelco a las expectativas sobre la investigación de usos potenciales de células madre. Hasta esse anõ era casi un dogma que las células madre adultas estaban tan diferenciadas que difícilmente serian útiles en terapia celular. Pero en julio de 2002 el grupo de investigación de la Universidade de Minnesota (USA) dirigido por la Profesora Catherine Verfallie publicó en la revista "Nature" (una de las mas Prestigiosa $s$ de la literatura científica y extremadamente exigente a la hora de publicar resultados) un estudio en el que demonstraba que células madre obtenidas de la medula ósea de los adultos podían diferenciarse en prácticamente todos los tipos celulares conocidos en el adulto y concluía diciendo que por tanto era la fuente de células ideal para el tratamiento de enfermidades degenerativas (Cf. Natures 2002 Jul 4;418(6893):41-49).

En diciembre de ese mismo año 2002, científicos de la Universidad de UCLA (USA) tienen hallazgos similares utilizando células madre obtenidas por liposucción. En este trabajo consiguen obtener incluso auténticas neuronas partiendo de estas células que procesan de la grasa (similares a las usadas en nuestra investigaciones) (Cf. Molecular Biology of the cell. Decembrer 2002; 13: 4279-4295)

\section{E concluiu o Professor García-Olmo, verbis:}

-- Son más idóneas para desarrollar terapias actualmente las células madre adultas que las embrionarias? Porque?

--Que sepamos, en España, no hay ningún estudio clínico aprobado para el uso de células madre procedentes de embriones. Esto es actualmente inviable por los enormes riesgos potenciales que conlleva (tumores, problemas de rechazo, necesidad de terapia inmunosupresora, etc.). Sin embargo, en España, hay al menos tres programas de uso clínico de células madre adultas en patología humana que estan demonstrando que el uso de estas terapias es factble y seguro. Estos grupos van a presentar sus resultados durante un simposio que se celebrará en el Hospital Universitário La Paz el próximo 18 de marzo. 
--Sin entrar en consideraciones éticas sino con los resultados clínicos en la mano, cree que la presión de algunos sectores por potenciar y dotar de recursos la investigación com embriones obedece a una real expectativa de obtener resultados o se mezclan en el tema cuestiones diversa a las meramente científicas?

--Lo que pienso es que la comunidad científica, después de muchos años de investigar sobre células madre embrionárias como la mejor fuente para la terapia celular, aún no há asimilado el cambio copernicano que se há producido en el conocimiento durante el año pasado. Tenga en cuenta que no hace ni un año desde la publicación de los trabajos de Catherine Verfaillie. Ademais los médicos clínicos tardamos bastante tiempo en asimilar lo que descubren los investigadores básicos."

(mesma entrevista grifei)

15. Na Alemanha, no plano legislativo, há específica lei de proteção aos embriões, definido pelo artigo $8^{\circ}, 1$ como, verbis:

"Por embrião nos termos desta lei entende-se, já a partir do momento da fusão nuclear, o óvulo humano fecundado e capaz de se desenvolver, assim como toda célula totipotente retirada de um embrião que, uma vez reunidas as condições necessárias, seja capaz de se dividir e se desenvolver num indivíduo." (vide: Lei alemã, em anexo)

16. A propósito, faço anexar a esta petição inicial, importante registro do il. Subprocurador-Geral da República, Dr. Eugênio Aragão, posto nestes termos, verbis:

"Atendendo a pedido de Vossa Excelência, encaminho, em anexo, a tradução livre do alemão para o português, de minha lavra, do "Gesetz zum Schutz von Embryonen" (ESchG) e do "Gesetz zur Sicherstellung des Embryonenschutzes im Zusammenhang mit Einfuhr und Verwendung menschlicher embryonaler Stammzellen" (StZG), correspondendo às leis alemãs sobre proteção de embriões humanos e sobre a importação e o uso de células-tronco, respectivamente. Coloquei em colchetes as adaptações de texto necessárias à melhor compreensão dos textos legais.

No geral, na Alemanha é proibido o uso de embriões humanos para fins outros que o de provocar a gravidez (ESchG $\S 1$, Abs. 1, S. 1). Por isso, não se prestam, embriões humanos, naquele país, à pesquisa científica. A lei de proteção a embriões humanos também proíbe expressamente a clonagem humana (ESchG, $\S 6$, Abs. 1). Isso vale também para a chamada "clonagem terapêutica", visto que, para os efeitos da ESchG, considera-se embrião humano toda célula totipotente, já no seu estágio mais primário, da fusão nuclear $(\S 8$, Abs. 1). 
Diferente é, pela legislação alemã, a situação de células-tronco embrionárias pluripotentes, ou seja, aquelas que não se podem desenvolver para virem a constituir um indivíduo. Estas podem ser usadas para fins de pesquisa científica. $\mathrm{O}$ problema está em garantir que tais células sejam apenas pluripotentes e não totipotentes.

Com a promulgação da lei sobre importação e uso de células-tronco humanas (StZG), de 28 de junho de 2002, passou-se a admitir expressamente, mediante permissão específica, o uso de célulastronco embrionárias importadas, desde que tenham sido geradas antes de $1^{\circ}$ de janeiro de 2002 e mantidas em cultura crioconservada (linhas de célulatronco). Exige-se, ademais, que os embriões que lhes deram origem tenham sido gerados no contexto de uma fecundação medicinal extracorporal para fins de provocar gravidez e que em definitivo não se prestaram a tal finalidade por razões que não contemplem a qualidade dos embriões. Por fim, é proibida a aquisição onerosa dessas células-tronco importadas (cf. StZG, $\S 4$, Abs. 2).

Este é o estágio atual da legislação alemã, pelo que Vossa Excelência pode depreender das anexas traduções.”(Doc. junto)

17. A Dra. Claudia M. C. Batista, Professora-Adjunta da UFRJ e pósdoutorada pela University of Toronto na área de células-tronco, afirma, verbis:

"No momento da fecundação, a partir da fusão do material genético materno e paterno, a nova célula formada, chamada zigoto, reorganiza-se, perde proteínas inicialmente ligadas ao DNA dos gametas, inicia um novo programa ditado por esta nova combinação de genes, comanda de forma autônoma todas as reações que o levarão a implantar-se no útero materno. Inicia-se uma "conversa química" entre esta célula e as células do útero materno. Este programa é, além de autônomo, único, irrepetível, harmônico e contínuo.

A partir da primeira divisão do zigoto, quando originam-se as duas primeiras células, estas encontram-se predestinadas. Estudos recentes da Dra. Magdalena Zernicka-Goetz, do Departament of Experimental Embryology, Polish Academy of Science, Jastrzebiec, Poland, (Cf. Nature. 2005 Mar 17;ai434 (7031): 391-5, Development. 2005 Feb; 132(3): 479-90; Development. 2002 Dec; 129(24): 5803-13; Nat Cell Biol. 2002 Oct; 4(10:811-5), mostram clara e irrefutavelmente que toda e qualquer parte do embrião ou feto é formada por células já predestinadas nas primeiras horas após a fertilização. Portanto, todo o desenvolvimento humano tem como marco inicial a fecundação e, após este evento, têm-se um ser humano em pleno desenvolvimento e não somente um aglomerado de células com vida meramente "celular". Trata-se, a partir deste evento, de um indivíduo 
humano em um estágio de desenvolvimento específico e bem caracterizado cientificamente".

18. Fica, pois, assente:

- que a vida humana acontece na, e a partir da, fecundação: o zigoto, gerado pelo encontro dos 23 cromossomos masculinos com os 23 cromossomos femininos;

- a partir da fecundação, porque a vida humana é contínuo desenvolver-se;

- contínuo desenvolver-se porque o zigoto, constituído por uma única célula, imediatamente produz proteínas e enzimas humanas, é totipotente, vale dizer, capacita-se, ele próprio, ser humano embrionário, a formar todos os tecidos, que se diferenciam e se auto-renovam, constituindo-se em ser humano único e irrepetível.

- a partir da fecundação, a mãe acolhe o zigoto, desde então propiciando o ambiente a seu desenvolvimento, ambientação que tem sua etapa final na chegada ao útero. Todavia, não é o útero que engravida, mas a mulher, por inteiro, no momento da fecundação.

- a pesquisa com células-tronco adultas é, objetiva e certamente, mais promissora do que a pesquisa com células-tronco embrionárias, até porque com as primeiras resultados auspiciosos acontecem, do que não se tem registro com as segundas.

19. Estabelecidas tais premissas, o artigo $\mathbf{5}^{\circ}$ e parágrafos, da Lei $\mathbf{n}^{0}$ 11.105, de 24 de março de 2005 , por certo inobserva a inviolabidade do direito à vida, porque o embrião humano é vida humana, e faz ruir fundamento maior do Estado democrático de direito, que radica na preservação da dignidade da pessoa humana.

20. Nesse passo - a preservação da dignidade da pessoa humana importa, aqui, reproduzir o pensamento do Dr. Gonzalo Herranz, Diretor do Departamento de Humanidades Biomédicas da Universidade de Navarra, verbis:

"El núcleo ético del argumento es este: no todos los seres humanos son iguales, pues unos tienen más valor y más dignidad que otros. En concreto, ciertos seres humanos, y los embriones congelados caducados se cuentan entre ellos, valen muy poco y podemos intercambiarlos por cosas más valiosas. No tienen nombre, ni son personas como las otras. Están condenados a morir y nadie los llorará ni celebrará funerales por su muerte, inevitable y autorizada por la Ley. Pero, como demócratas, se ha de replicar que no es justo ni razonable dividir a los seres humanos en grupos de valor diferente. Los embriones sobrantes son, ante todo, hijos, que forman parte de una familia. Formaban parte de un grupo de 
hermanos. De ellos, unos fueron considerados dignos de ser transferidos al seno de su madre y son ahora niños llenos de alegría de vivir. Pero, por un azar trágico, los otros fueron dejados de lado. La humanidad ha madurado trabajosamente la idea de que a todos los miembros de la familia humana se ha de conferir la misma dignidad, aunque sus ideas o su apariencia difieran radicalmente de las propias."

(El sacrificio de prisoneros de guerra y los embriones congelados - Diário Médico - 6.11.02)

\section{E, conclusivo, verbis:}

Las vidas humanas no valen menos porque nadie las llore. La saturación de tragedias que nos revela el telediario cada día está quemando nuestras reservas de compasión. Nuestra capacidad de comprender y emocionarnos no nos alcanza para conmovernos por los que mueren a consecuencia de catástrofes naturales, accidentes, crímenes terroristas o no, sobre todo si ocurren lejos de nosotros. No se llora por los embriones que se pierden espontáneamente o que son abortados. Pero no ser llorado, no ser conocido o no ser deseado no hace a esos seres menos humanos o menos valiosos. La deficiencia de valor no está en ellos.

Total, van a morir... Pero nuestra postura ante su muerte no es asunto indiferente. El modo y las circunstancias de su muerte son asuntos éticamente decisivos. Y una cosa es reconocer lo inevitable de su muerte absurda que pone fin a una existencia todavía más absurda, y otra muy distinta es consentir en su sacrificio en el altar de la ciencia y sentirse redimido y justificado. Su muerte, inevitable, no es pasivamente presenciada, sino que es activamente consentida, programada, usada en beneficio propio. Es reducir a los embriones a la condición de meros medios con los que se satisfacen los deseos de otros: al principio, para cumplir unos proyectos parentales que los han dejado en el frío; después, unos proyectos de investigación que los dejan crecer hasta blastocistos de cinco días para reconvertirlos en células que nada tienen que ver con su propio proyecto de vida. En Bruselas han optado por pensarse un poco mejor donde poner el dinero. Nosotros necesitamos también tiempo para decidir donde ponemos el alma, porque estamos ante una decisión histórica. Paul Ramsey lo dijo muy bien: 'La historia moral del género humano es más importante que la historia de la Medicina'."

(ainda trecho outro do artigo citado acima)

III - Do Pedido:

1. Advindas informações do Congresso Nacional, da Presidência da República, colhido o pronunciamento da Advocacia Geral da União, e tornando-me os autos a parecer, peço, presentemente, a declaração de inconstitucionalidade do artigo $5^{\circ}$ e $\S \S$ da Lei 11.105, de 24 de março de 2005 . 
2. À luz do disposto na parte final, do $§ \mathbf{1}^{\mathbf{0}}$, do artigo 9, da Lei $\mathrm{n}^{\circ}$ 9868/99, solicito a realização de audiência pública a que deponham, sobre o tema, as pessoas que apresento, e que comparecerão à audiência independentemente de intimação, tão só bastando a este Procurador-Geral da República a intimação pessoal da data aprazada à realização da audiência pública:

1. Professora Alice Teixeira Ferreira;

2. Professora Claudia Maria de Castro Batista;

3. Professora Eliane Elisa de Souza e Azevedo;

4. Professora Elizabeth Kipman Cerqueira;

5. Professora Lilian Piñero Eça;

6. Professor Dalton Luiz de Paula Ramos;

7. Professor Dernival da Silva Brandão;

8. Professor Herbert Praxedes; e

9. Professor Rogério Pazetti.

Brasília, 16 de maio de 2005.

CLAUDIO FONTELES

PROCURADOR-GERAL DA REPÚBLICA 